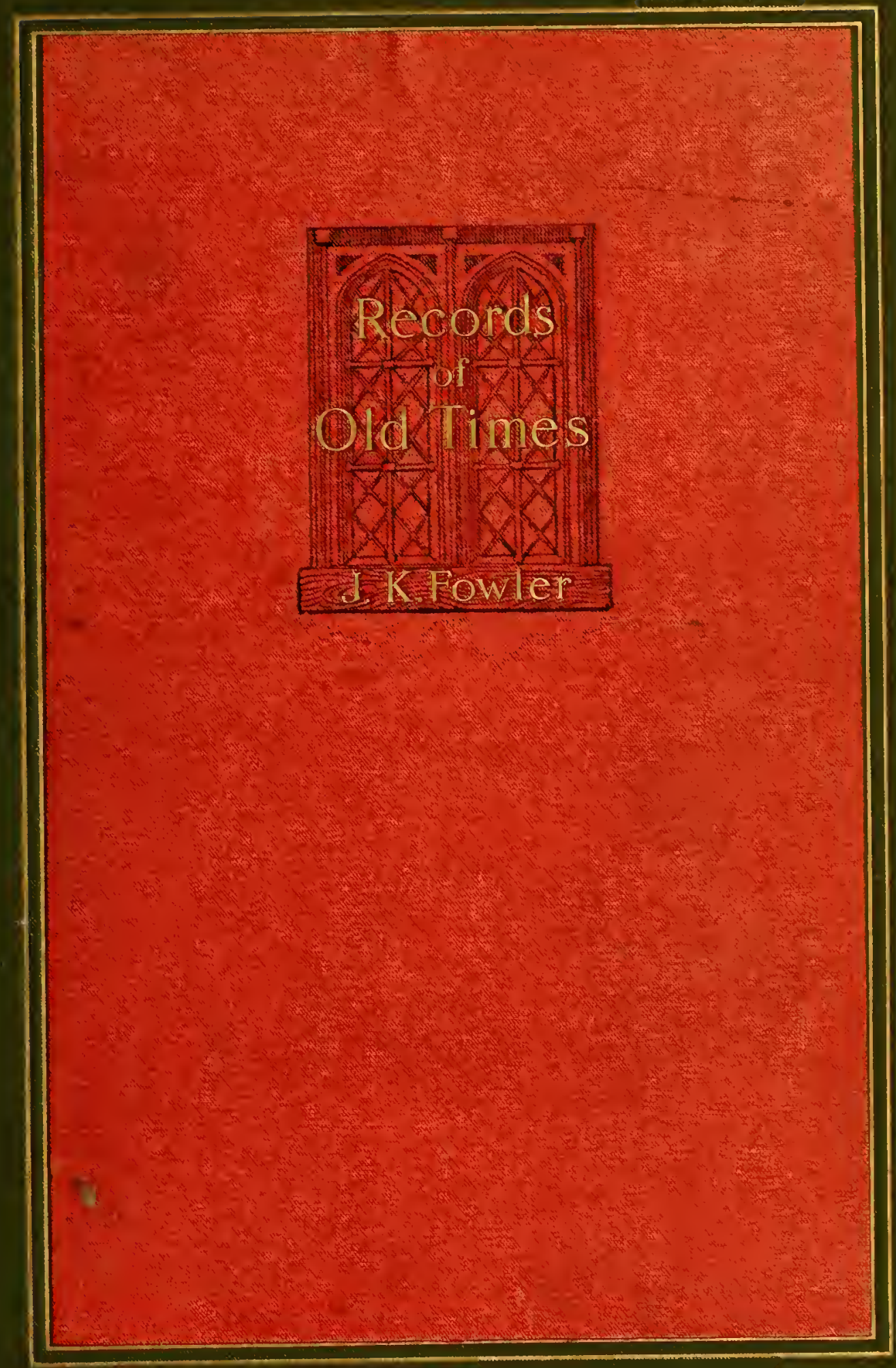



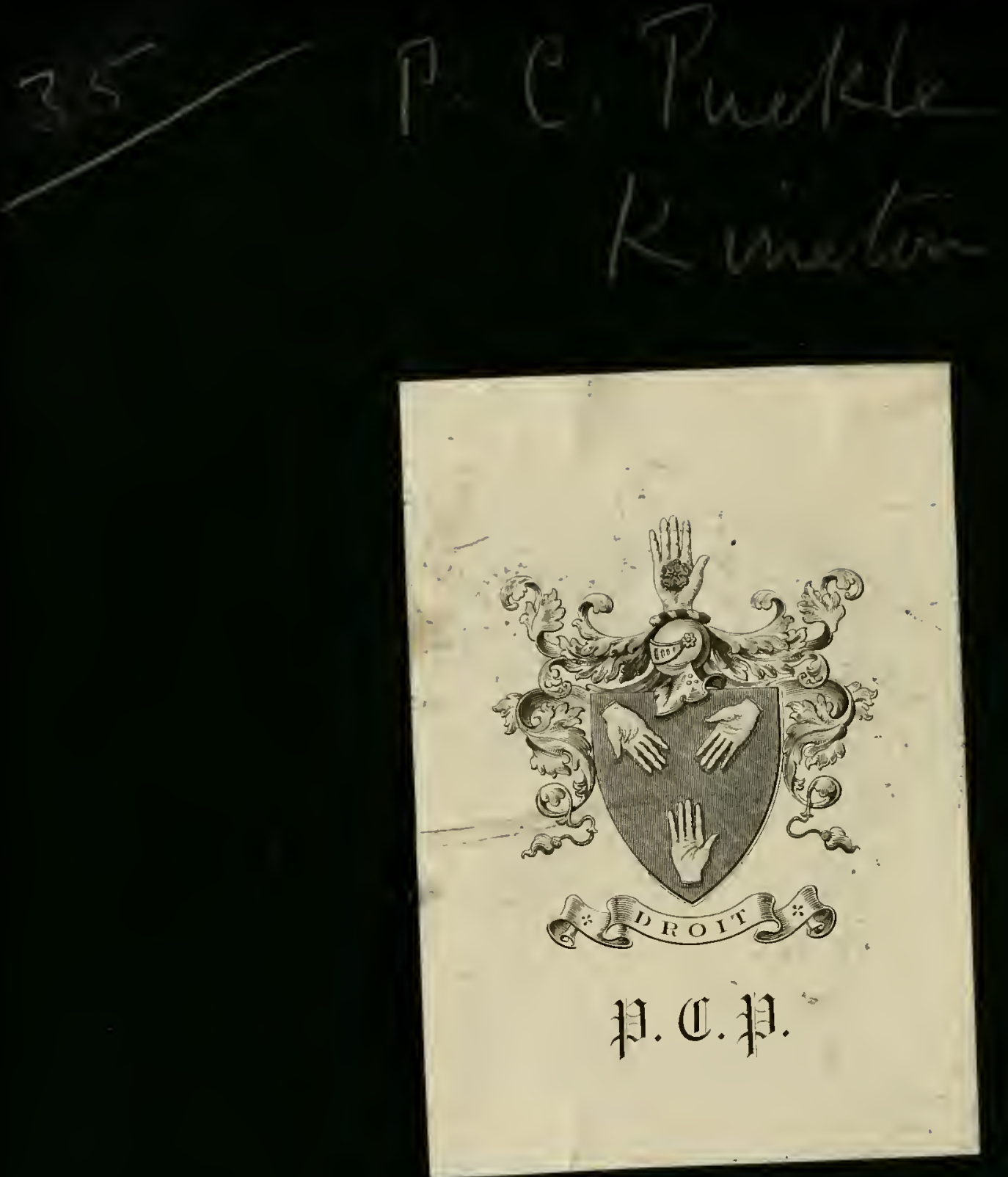


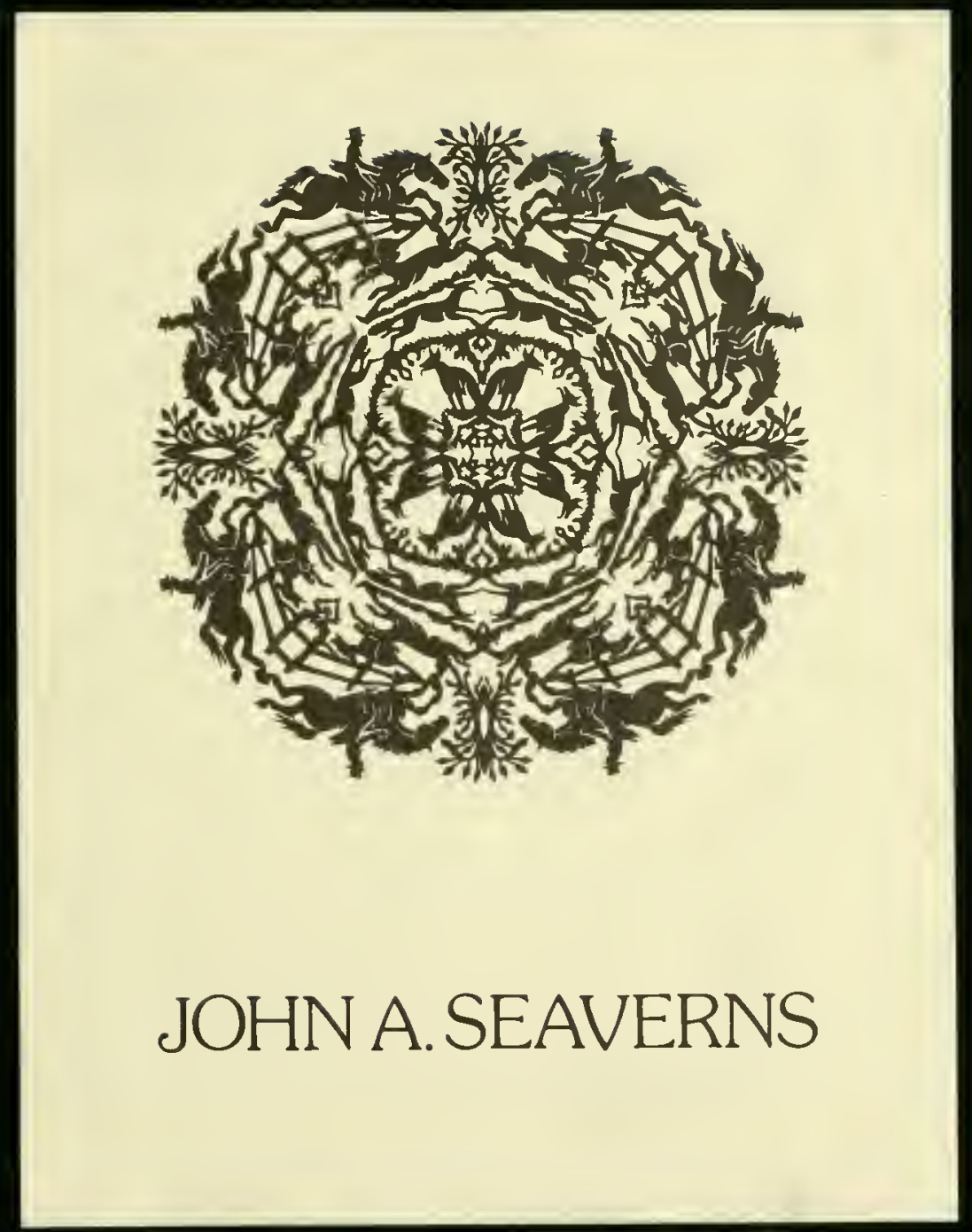


$4 \delta=\frac{108}{0}$

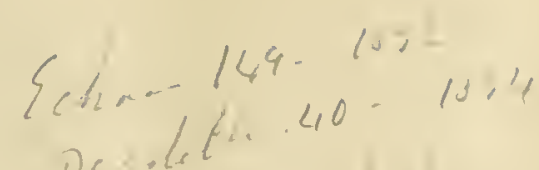

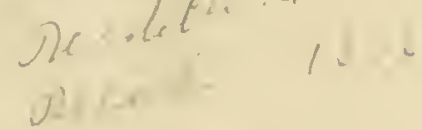


Only 75 Copics of this LARGE-PAPER EDITION lar'e becn printed

This is No. 3.5 



\section{Znecolds af old Timrs}





\section{.}




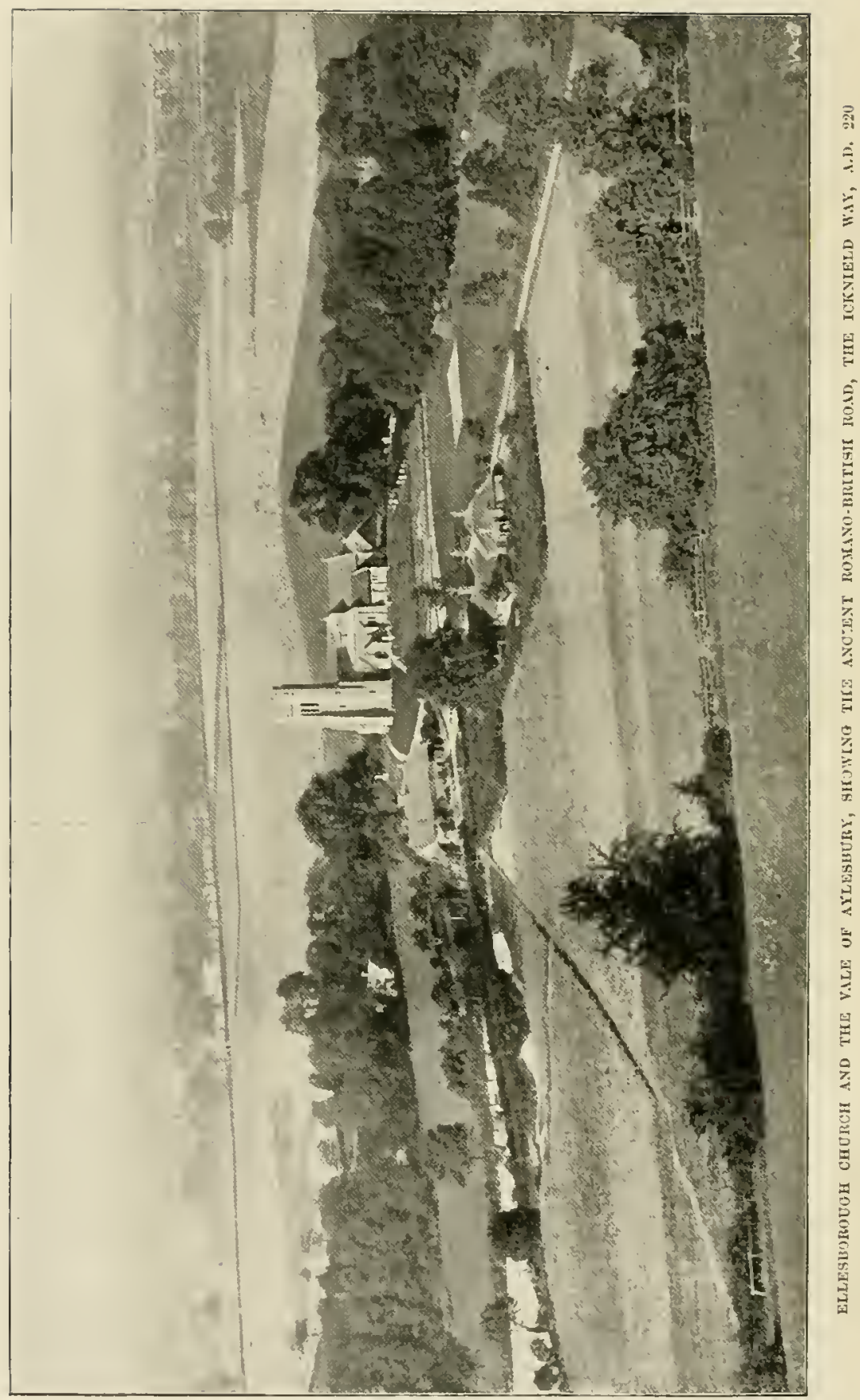




\title{
RECORDS OF OLD TIMES
}

\author{
HISTORICAL, SOCIAL, POLITICAL, SPORTING
}

AND AGRICULTURAL

BY

\section{J. KERSLEY FOWLER ('RUSTICUS')}

formerly of the Prebendal Farm, Aylesbury

AUTHOR UF

'ECHOES OF OLD COUNTY LIFE' AND 'RECOLLECTIONS OF OLD COUNTRY LIFE'

\begin{abstract}
"How strange are the tricks of memory, which after a hazy' drean about the most important events of a man's life, religiously preserves the merest trifles! And how very unpleasant to meet oneself thirty years younger!'-LIFE OF BLIRTON

"When you say to a well-known man, "You ought to write your memoirs," it is a polite way of giving him to understand that he is no longer fie for anything else. Still people continue to publish their reminiscences, because a man likes to call up his sonvenirs, and because, as a result of evoking them for himself, the moment comes when he is seized by a desire to communicate them to his contemporaries'-HENRI ROCHEFORT
\end{abstract}

IVITH NINE ILLUSTRATIONS

\section{LONDON}

CHATTO \& WINDUS

1898 

TO TIIE RIGIIT IIONOURABLE

\section{LORD ROTHSCHILD}

LORD-LIEUTENANT OF BUCKS

FROM WHOM AND HIS FAMILY BOTH ABROAD AND AT HOME

I HAVE RECEIVED MANY ACTS OF KINDNESS

AND COURTESY

I DEDICATE TIIS BOOK 



\section{PREFACE}

The great success of my two former books, 'Echoes of Old County Life' (E. Arnold), and 'Recollections of Old Country Life' (Longmans), with the

generous and unstinted praise accorded to them by nearly all the London and Provincial press, has emboldened me to bring out another volume, which I have called 'Records of Old Times.' This will complete a Trilogy that I am vain enough to believe will prove agreeable to my former readers, comprehending, as it does, a series of reminiscences of interesting events in which I have been a moving centre, as well as 'Old Records' which I have been enabled to glean in my researches relating to Buckinghamshire and the neighbouring counties. In my first volume I ventured to remark 'that these reminiscences differ from others that have hitherto been published ... as being a fair representation 
of middle class life of one who, in the course of a busy career, had met many famous people, and truthfully recorded what he remembers about them.' In the present volume I have somewhat enlarged on the subject, by adding interesting facts of past history, more especially the history of my native county and the old town of Aylesbury, where I was born, and where I lived for more than sixty years. This is a long period to recall, but being possessed of a vivid memory, it has not been difficult for me to relate circumstances but little known to the present generation, many of which, I may venture to say, are calculated to be of use and guidance in the future. My records of Turnpike gates and their keepers; Posting and Post-horses, with a description of the 'post-horse duty,' and how that vexatious impost was raised and collected; of old inns and coaching, with the rise of the present so-called hotels and the huge caravanserais which are now prevalent in our great MIetropolis, as well as in our seaside resorts and great manufacturing towns; the development of modern systems of agriculture, and of agricultural exhibitions, abroad and at home; of Steeple-chasing and other sports, with early Parliamentary and social records, comprise 
a series of subjects which, I conceive, cannot fail to interest various classes of my readers. Possibly I may sometimes have travelled over the ground covered in former volumes. If I have, I apologise. When, however, that occurs, it is traceable, on my part, to a desire to clearly elucidate some striking event, for the perfect comprehension of which a note or two of repetition would be necessary.

I must tender my best thanks to Lord Rothschild for his kindness in permitting me to dedicate this book to him ; and I but express my own feeling and that of the public in stating how much the great world is indebted to the present and past three generations of his family for their integrity in business, their well-known charity and hospitality, with the attention they have shown to the wants and requirements of their tenantry, and of Agriculture in general, as well as the performance, by the present head of the house, of his important duties as Lord-Lieutenant of Bucks.

Although Lord Rothschild has been in occupation of Tring Park only a few years, he has so much altered and beautified its interior as to make it a home fit for a nobleman of such taste as he possesses. For many years the house was occupied 
by the Rev. I. Williams, who held it under the trustees of Mr. Kaye, and at his decease the mansion and large estates were sold by auction. The eldest son of Mr. Williams was very desirous of purchasing it, but at the auction Lord Rothschild became the purchaser at something approaching $250,000 \%$, the timber, which was very extensive, being taken at a valuation. The enclosed deer park makes a great addition to the property, and its easy access to London is of much consequence to the occupier. From several sources, especially from a description given in a number of 'Country Life' of June 5, I 897,1 find that the manor of Tring (of the famed 'Tring, Wing, and Ivinghoe') was granted to Earl Eustace by William the Conqueror, from whom it descended to Matilda, wife of King Stephen. It then became the property of the Abbot of Feversham, from whom it passed to Edward III., who, in exchange, granted it to the Archbishop of Canterbury, in whose possession it remained till Henry VIII., when plundering the revenues of the Church, vested the property in the Crown. The manor remained a Royal possession till the time of Charles I., who presented it to his Queen, Henrietta Maria. Oliver Cromwell, 


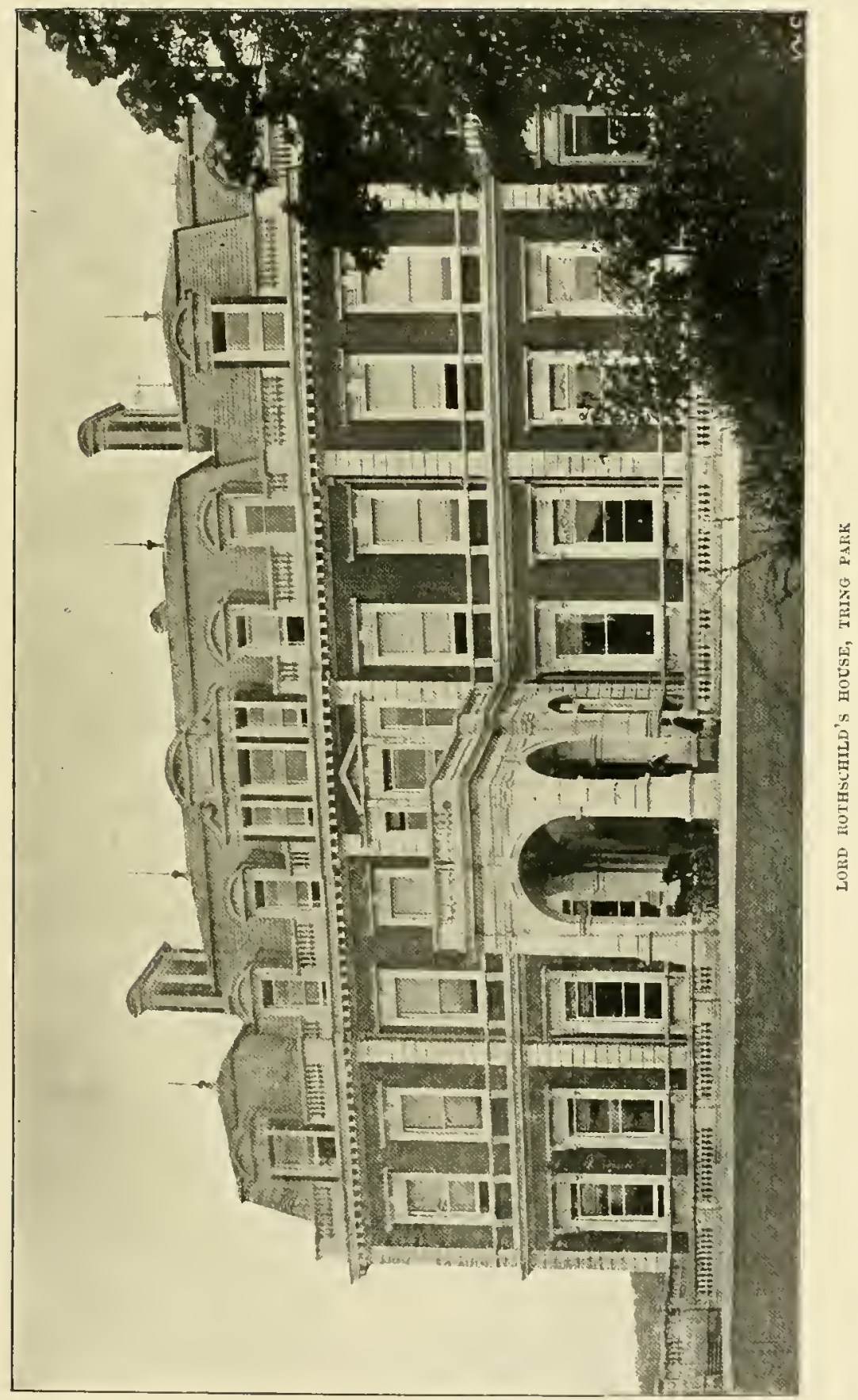



however, confiscated it to the Commonwealth, and it is recorded that a private gentleman again purchased the property and presented it to Charles II. after the Restoration. I believe the King occasionally resided at Tring Mansion, which probably gave rise to the report that Nell Gwynne was once the possessor. The estate then became the property of Mr. Henry Guy, who was Clerk to the Treasury for four reigns. He built the chief part of the present mansion. In the end it belonged to Sir Drummond Smith, from whom it passed to Mr. Kaye, who was in the silk trade, and, I believe, connected with David Evans \& Co. Mr. Kaye, during the agricultural depression in the early forties, established considerable silk factories at Aylesbury and Tring, in order to find employment for the agricultural poor. The Aylesbury factory has been closed for some years, but the present Tring factory is continued by Lord Rothschild's philanthropy, and still finds employment for many. The house and park closely adjoin the little market town of Tring, and the members of the local agricultural association have the privilege granted them of holding their annual show in the park, the denizens of which, acclimatised, and carefully attended to by the 


\section{xii RECORDS OF OLD TIMES}

Hon. Walter Rothschild, the eldest son, always excite great interest; there are to be seen zebras, kangaroos, emus, tortoises, and other curious specimens of foreign countries, which seem to progress very well in their new surroundings.

My thanks are also due to my old friend Mr. Samuel Glen Payne, and his talented wife, for their permission to use the excellent photographs of mansions, churches, and other places of note to illustrate the book. In addition, I have to thank those who have furnished me with memoranda in explanation of the incidents mentioned.

THE OLD HoUSE, HAMPTON-ON-THAMES, January 1898. 


\section{CONTENTS}

\section{CHAPTER I}

The county of Bucks-The Chiltern Hills-Vale of AylesburyValley of the Thames-North of the county: Valley of the Ouse-'The classic groves of Stowe'-'Cymbeline'-An American's opinion--'Why you English people so deeply love your country'-White Leaf Cross-Hughenden-Benjamin Disracli-'Tring, Wing, and Ivinghoe'-The making of England-Anne Boleyn, 'The Fair Maid of Aylesbury'

\section{CHAPTER II}

Turnpikes and their keepers-Origin of turnpike trusts-General rate of tolls-Mr. IVeller's opinion of pike men-A turnpike letting-'Pikers' and their methods-Sharp practice-Lessees of tolls-Feasting after the fray-Mianagement of roads

\section{CHAPTER III}

Early recollections of posting-Post-horse duty-The old inns and posting-houses-Collection of the duty-Manners and customs of travellers who posted-Cost-Post-horse Farmers -Shillibeer, the well-known Undertaker-Abolition of the duty

\section{CHAPTER IV}

Eton Montem-Customs - Their origin - Collecting salt Waving the flag on the Mount ad Monten-Salt bearersThe 'Windmill' Inn-Mr. Botham-The traffic on the Great Western road-Royalty-The Playing Fields-Dr. Goodall -Dinton. 


\section{CHAPTER V}

Early recollections of the Derby-Lord Berners and Phosphorus in 1837-Caravan and Lord Suffield-My first DerbyBloomsbury's year, 1839-My costume-Heavy snowstorm on Oak-apple Day, May 29-Opening of the London and South-Western Railway from Nine Elms-' No more trains!' - Cab to Kingston-A borrowed ride on a post-chaise'Whip behind!'-A mad rush, but in time to see the finish -Amato's victory-From Aylesbury to Epsom on horseback in I84I-Well-named Little Wonder: won with 40 to I against him - The Queen and Prince Albert present Running Rein-Daniel O'Rourke-My folly .

\section{CHAPTER VI}

Recollections of the Cup Day at Ascot-My ride from homeThe Queen, Prince Consort, and the Emperor of Russia: interesting conversation-The Countess of Albemarle's carriage-The Earl, Master of the Horse, wins with his son of Defence, beating Attila-Delight of the crowd-The Emperor's promise to present the Ascot Cup in future-Establishment of the Crasarewitch Stakes-The Defence colt called the Emperor-IVins the Vase the following year-Graceful act of the Earl : presents the Vase to her Majesty the Queen, and the horse to the Czar-My next 'Ascot'-Dead-heat between Buckstone and Tim Whiffler. . . . . .

\section{CHAPTER VII}

Parliamentary elections-Origin of the representation of the people-Alfred the Great and the Witanagemot-Ancient franchises-The Potwaller-Borough of Aylesbury-Addition of 'The Hundreds'-John Webb, ninety-six years old, the last of the Potwallers-Customs at the nomination-Dinners -Conveyances - Duration of polling period-A candidate's 'little bill '-The poll-The voters' dinners : daily bill of fare -General Election of 1784 -Curious incident-The great Aylesbury case, Ashby \%. White-1 ts effect . . . . 56 


\section{CHAPTER VIII}

An eccentric country gentleman-Egyptologist and astronomer - Singular political career-Rural pursuits-His marriagesEstablishment of prize gooseberry shows-Practices of exhibitors-Names of noted gooseberries-Jas. Carter, landlord of the 'Bugle' Inn-Teetotal festivities-Dr. Lee in excelsisElihu Burritt-Drunken orgies of the visitors to the Teetotal banquets-The historic career of the Lee family-Their remarkable infuence-Admiral Snyth-Old Wiggs, the parish clerk-'Edes Hartwellianz'-The museum-Hartwell House, the seven years' residence of Louis XV111. 73

\section{CHAPTER IX}

A prize farm-A Yankee fellow traveller-American and English farmers compared-Turning the tables-An English farmer's bill of fare-A farmer's 'pretty turn-out'-Discomfiture of the Professor-Wheat-growing in England and the United States-The Professor's apology . . . . . . 89

\section{CHAPTER $\mathrm{X}$}

Hereford cattle-Early history of the breed-Report of the United States Government-Grazing capabilities-Quality of beefCurious anecdote-Mr. Westcar, of Creslow-Foundation of the Smithfield Club-introduction of the breed into the Midlands-Duke of Bedford-Lord Berners-Remarkable cattle -Great value of 'Hereford' beef at Christmas-Beauty of the animals-Colour, grandeur, and carriage--General aptitude to fatten .

\section{CHAPTER XI}

Odd inns-Politics - Inn signs and their origin-Posting and coaching-The 'White Hart' at Aylesbury-The extensive gardens, the offices, and appointments of the 'White Hart' - County importance of the grand old inn-Names of the rooms-The 'Old Bell' in Holborn-Customs of the dinnertable-To Drury Lane Theatre after dimner - Other old inns -Rise of the modern hotel-Bacon's Hotcl, Great Queen Strcet-Railway hotels-Present managers and past proprietors contrasted. 


\section{xvi \\ RECORDS OF OLD TIMES}

\section{CHAPTER XII}

News of the Battle of Waterloo-Difficulty and delay in getting news at the beginning of the century-The old Winslow coach-'The Dairy Naid'-Report of the great battle brought to my father-Doubts of its authenticity-Ringing the church bells-Indignation of the vicar-Ultimate triumph of my father-Then and now contrasted- Our own correspondent

\section{CHAPTER XIII}

A famous hunting mare-The purchase: her infirmity, her great beauty, and her matchless performances-Her docility and extraordinary pace-Jem Mason-Harborough Brown-The Creslow Brook-The beauty of the Vale of Aylesbury as a hunting country-Famous run after a bag fox with Lord Lonsdale's hounds-Captain Barlow-Lord Coventry-The great water jump over the Broughton line of country with the 'Varsity men-Accident to the mare-Partial recovery-Put to the stud-Sudden death-Death of her foal by Hungerford at four years old, and an end of the great huntress . .

\section{CHAPTER XIV}

Curious instance of life insurance-X, a specially fortunate speculator in freehold property-His remarkable purchase of life interest of a younger son of a peer-Death of the earl, of the heir, with other deaths-The younger son heir to the earldom and 50,000 . a year-Enormous windfall to $\mathrm{X}$ - H is noble generosity to the impecunious peer-His attempt to insure his life-Unwarrantable refusal to appear before the company's doctorSudden withdrawal of proposal by X-The end of X's career

\section{CHAPTER XV}

The Date Coffee Company-Discovery of the value of the date as an infusion equal to the best coffee-Successful flotationEstablishment of the patent-Manufacture of date coffee at Kurrachee in India-The I maum of Muscat-Rapid increase in the consuniption-Handsome profits-The French patent and its sale-Flotation of German company-Sudden collapse 
of the sale of the article through the action of $\mathrm{Mr}$. Gladstone, Chancellor of the Exchequer-The Date Coffee Company in the Law Courts-Final break-up of a company whose $5 \%$. shares had for some time been quoted at $37 \%$.

\section{CHAPTER XVI}

Catpital punishments-Crimes of every description that were punishable by death-Numbers at every assize left for execution-Banks and the two Cribbs for horse-stealing-Sheepstealers-The new drop-Baron Garrow-A hanging judge -The riots in 1832-John Thompson at Maidstone-lnstance of superstitious belief in the charm of the dead hand-Mislaid death warrant found, and, years after sentence, woman taken from wash-tub and hung

\section{CHAPTER XVII}

Witclicraft-Its extraordinary superstitions-Biblical authorities -Joan of Arc-The Puritans-Henry VI11.-Sir Natthew Hale-Ducking at Castle Hedingham-Ruth Osborne drowned at Cubblecote-Verdict of murder-Conviction and execution of Colley-Susanna Hannock at Wingrove weighed against the church Bible - Visit of the Fiery Drake to Aylesbury Gaol-Prognostication before the assizes of death sentences

\section{CHAPTER XVIII}

Early steeplechasing-Qualities of a good steeplechaser-St. Albans in I833-34-Aylesbury-Moderate stakes-The rise and temporary fall of the Aylesbury meeting--Young 'Oxford' at Aylesbury vice Banbury abandoned-A tremendous line of country-Twice across eighteen feet of naked water and over a turnpike road-'Grief'-Well-known cross-country gentlemen riders at Aylesbury - Their hardihood and pluck-A cruel course and unjumpable fence-A carefully laid-out line at Aylesbury-Abuses and their reform-A great meetingH R.H. the Prince of Wales prevented from being present -A defaulting official-The late Earl of Darnley-Reminiscences of 'Varsity steeplechasing-Assumed names of the riders-The disguise stripped off by 'Bell's Life'-Bishop Wilberforce and the steeplechases. 


\section{xviii RECORDS OF OLD TIMES}

\section{CHAPTER XIY}

History of a railuay-Opening of the London and Birminghan, now the London and North.Western-The Buckinghamshire -George Stephenson and his son Robert-The AylesburyMessrs. Brydone and Rummens-Mlarquis of Chandos-Mlr. Stewart, secretary to London and North-Western-Unfair opposition of landowner-Contracts and their effect-Directors' advances-The Great Western-The Metropolitan-Purchase of the A and $B$ line-Shameful treatment of the original directors - Their just claims ignored - The Manclester, Sheffield, and Lincolnshire (Great Central) . . . . .

\section{CHAPTER XX}

Altona-Judge in agricultural department at the great SchleswigHolstein Exhibition-My fellow jurors-The officials' utter ignorance of ' management ' - Chaos-Assisted by the English exhibitors, orderly arrangement effected-Awards-Trials of implements : difficulties that had to be removed-Thrashingmachines: Walter Wood his own driver-He wins the first prize-Horticultural Show at Hamburgh-The success of the English-Liverpool grapes win against all comers-Shabby treatment of the judge-Nonpayment of services and out-ofpocket expenses-Journey home-Borrowing money to get there - Opinion of foreign agriculture - The all-round superiority of Englisla methods . . . . . . 196

\section{CHAPTER XXI}

Amsterdam-Appointed a judge at the great Exhibition-The journey thither-The Poultry Show-My son Robert wins the gold medals for poultry and waterfowl-Extraordinary weight of prize birds - Paul Potter's bull - 'A wretch' of a beastCurious facts in heredity - The famous bull as a pictureDescription - The Alderney Bull, by James Ward, R.A. - 'Duke of Connaught' - Trotting matches-Dutch cattleMilk production and bacon-Tranquil beanty of the Low Countries-The Dutch : their thrift, cleanliness, and industry - The bulb-farms at Haarlem 


\section{CHAPTER XXII}

The myths and monastic legends of Buckinghamshire-St. Osyth-Rip Van Winkle and the Seven Slecpers-The beheading and miraculous restoration of St. Osyth-The Nun's Wood and Fountain-Existing local traditions-Sacred wells - The Holy Touch'-Hartwell and Dr. Lee . . . 213

\section{CHAPTER XXIII}

Poultry rearing for profit-Statistics of imports-Breeds that should be adopted-Records of exhibition birds-MajorGeneral Hassard-Pheasant-rearing and the production of pheasants' eggs as a profitable agricultural industry - Remarkable statistics-Prices of eggs-Names of noted dealersAccounts of profit and loss-Numbers of eggs laid and young pheasants reared-Expenditure on the establishment of a pheasant farm .

\section{CHAPTER XXIV}

The homing instinct-André's pigeons-Mr. TegetmeierCurious instances of homing instinct in the dog-Quaint epitaph-The agricultural labourer-Dialects-The agricultural labourer's rustic speech-His humour-The worth and native shrewdness of his character-His industry-Wages and the cheap loaf-Old times and new-Bounties on foreign grown sugar-The growth of flax and hemp-A chance for English agriculture-' The backbone of Old England' 



\section{LIST OF ILLUSTRATIONS}

Ellesborough Church and the Vale of AylesBURY, SHOWING THE ANCIENT ROMANO-BRITISH ROAD, THE ICKNIELD WAY, A.D. 220 . . Frontispiece

LORD ROTHSCHILD's House, TRING PARK - . to face $p$. $\mathbf{x}$

Great Kimble Village and Church, with the ICKNIELD WAY • . • • • . . " ", 4

WhITELEAF CROSS-FORMED BY THE SAXONS TO CoMmemorate their final Victory over THE DANES, A.D. 570 • . . . . . " " 6

Dinton Hall, the Seat of Colonel Goodall; FORMERLY THE RESIDENCE OF SIMON MAYNE,

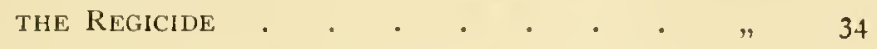

Hartwell House, the Residence of Colonel, E. DYKe-LeE; OCCUPIED, Whilst in Exile, BY LOUIS THE EIGHTEENTH FROM I807 TO 1814 " 74

$\left.\begin{array}{l}\text { Steepie-Chase, Old Stvle, Aylesburv, } 1847 \\ \text { Steeple-Chase, New Style, Lingfield, } 1897\end{array}\right\}$ • " 170

'The Young Bull,' By Paul Potter. . " 206 



\section{RECORDS OF OLD TIMES}

\section{CHAPTER I}

The county of Bucks-The Chiltern Hills-Vale of Aylesbury-Valley of the Thames-North of the county: Valley of the Ouse--' The classic groves of Stowe'-'Cymbeline'-An American's opinion'Why you English people so deeply love your country' - White Leaf Cross-Hughenden-Benjamin Disraeli-'Tring, Wing, and Ivinghoe'-The making of England-Anne boleyn, 'The Fair Maid of Aylesbury.'

'England, with all thy faults, I love thee still-my country.'

OncE more am I tempted to record my recollections of old England, as also, here and there, of certain other countries whereof I have some knowledge, and in the characters of whose great men I have taken unusual interest. In my former volumes I have given a somewhat disjointed record of my personal experiences of some interesting characters, chiefly from my native county-men of all classes with whom I have been associated; and I may be thought too enthusiastic in my love of the 'great historic county of Bucks,' so aptly named by one of her most distinguished sons, Benjamin Disraeli, who, although not born in the county, spent all his early boyhood and his most famous 
manhood at his father's house at Bradenham, near High Wycombe, and at Hughenden, which adjoins the former place. These villages are situated in the most picturesque parts of the 'beechclad Chilterns,' embedded in the umbrageous shelter of the beech trees, truly 'recubans sub tegmine fagi.' Much as I have travelled over Europe, and nearly the whole of the United Kingdom, I have repeatedly said that nowhere can be found more perfect sylvan scenery than that along the Chiltern Hills, or more real pastoral beauty than the Vale of Aylesbury, or more lovely views than those in the Valley of the Thames, from Henley to Maidenhead. Nor should the north of the county be despised. The Valley of the Ouse, the classic groves of Stowe, the woodlands around the Claydons, with the breezy heights of Brill, are all admirable.

But it is with the country about the Chiltern Hills I am tempted most to dwell, and the recent revival by Sir Henry Irving at the Lyceum Theatre of that most delightful play of Shakespeare, 'Cymbeline,' with the delineation of everything that is lovable, womanly, and charming in Imogen, has touched a chord which impels me to dwell on that interesting district. This part of the county is but little known; yet it is here that the two rural villages of Great and Little Kimble are situated, at the foot of the highest part of the Chiltern range, and here most undoubtedly dwelt the British King Cymbeline, or Kimbeline, with the 'fair Imogen' 
-all around the country is full of ancient British earthworks. It is generally believed that a deep and lovely indentation in the Chalk Hills is the spot where Cymbeline and his Court lived. This portion of the hill is covered with a deliciously short velvety sward, and verifies properly the modern appellation of 'Velvet Lawn.' On its east side rises abruptly a wonderfully perfect British camp, with a somewhat deep fosse or ditch thoroughly enclosing it ; and rising sheer from the base is one of the most beautifully shaped conical hills on the whole Chalk range, whilst on the top are two additional smaller camps, and within a quarter of a mile towers the highest of the Chilterns, called 'Coombe Hill'; this is about 900 feet above the sea, and commands a view of the country for a distance of nearly thirty miles. From its summit can be seen to the north and west portions of the counties of Warwick, Gloucester, Northampton, Oxford, Bedford, Hertford, Berkshire, and Wiltshire; and to the south Middlesex and the Surrey hills, with the Crystal Palace clearly visible. The most fertile part of Bucks lies at its foot, with the county town of Aylesbury.

The 'Egilsbireg' of the Saxons, surmounted by its fine old twelfth-century church in the centre of the vale to which it gives its name-I have not the power to clescribe the beauties of this splendid inland view. Some years ago from this spot I was showing a young American gentleman, who was visiting me, the beauties of this neighbourhood, with 
the country divided by hedgerows and planted with timber-trees, villages and parish churches rising here and there, and dotted with farm-houses and cottages, the river Thame meandering through the rich pastures, till it reaches the market town of that name, where it becomes a tolerably broad stream, falling into the Isis at Dorchester in Oxfordshire, the lsis having received the Cherwell, flowing from Banbury to Oxford, and thus forming the Thame-Isis, the Tamesis, or Thames, and becoming at London Bridge the richest laden and most noted river in the world. This unique view caused my friend to exclaim, 'Now I see why you English people so deeply love your country.' I replied: 'Yes, what you perceive has taken us nearly 2,000 years to create.' I then pointed out to him that at our feet lay the two little villages of Great and Little Kimble, and that there was the residence of the faned British King ' Kunobelin,' the 'Cunobelinus' of the Romans, and the 'Cymbeline' of the immortal Shakespeare, and that in the thickly wooded slopes of these hills had lived that most lovely woman of all the great poet's creation, 'the gentle Imogen.' We descended from our coign of vantage, and seated ourselves on the camp, still called by the country people 'Linus' Camp.' Looking to the side of the hill-covered thickly, and almost impenetrably with ancient box trees, stretching for miles-the trees are supposed to be the successors of former denizens of the slopes, and to have existed for many centuries. 


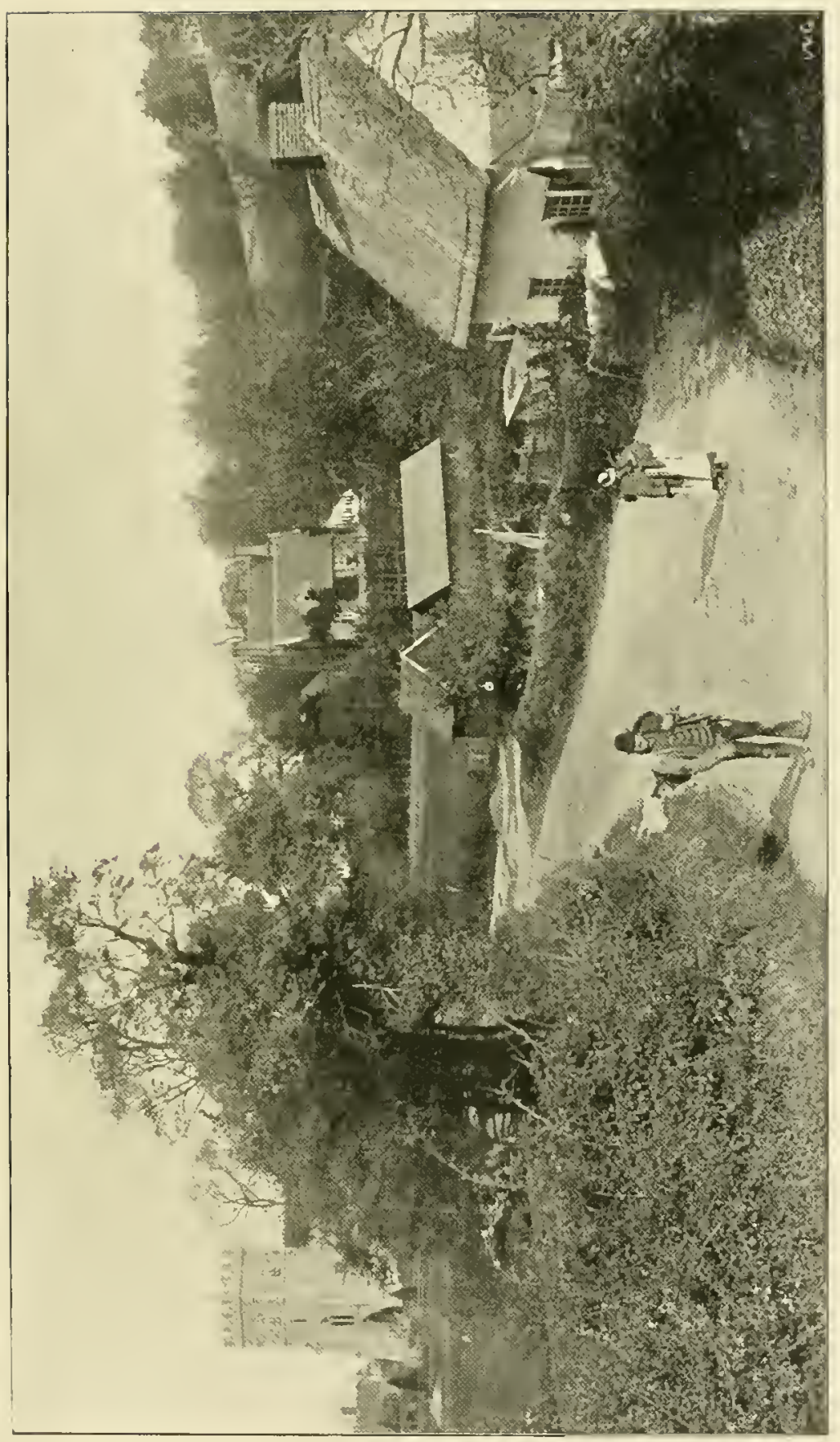

政 

These evergreen woods are extremely beautiful, and are interspersed occasionally with fine beech trees; the woods reach down to the two Kimbles, and the village of Ellesborough, or Ethelburga. I showed him that important British road-the 'Icknield Way,' the 'Via Iceni' of the Romansthe road to the Iceni of Boadicea, that great queen of a noble race, who was struck down, and, it is said, killed at the battle with the Roman legions near St. Albans. This road commences at Devizes in Wiltshire, continuing its route to the Thames, which it crosses at Wallingford, or Watlingford. to the little town of Watlington, then to Princes Risborough-once the residence of the Black Prince -along the foot of the Chiltern range to Dunstable, where it crosses or joins the main Roman road to the north-the "Watling Street' of these pioneers of civilisation still bearing the same name in the City of London-and on by Towcester to Chester. The Icknield IVay continues across the kingdom to St. Albans - the 'Verulamium' of the Romans, whose glorious Norman Abbey, now a cathedral, is largely built of Roman bricks from that warlike station. To our rear, amongst the dense mass of beech trees, lies Hughenden, which is about seven miles distant, the residence of the great political chief, the late Benjamin Disraeli, Earl of Beaconsfield, K.G., from whose residence, he once told me, while I was visiting him, that Simon de Montfort went to compel King John to sign Magna Charta at 
Runnymede near Ankerwyke on the Thames; and about two miles away is Hampden House, the birthplace and grave of the patriot, John Hampden, of whose ancestor it is recorded-

Tring, Wing, and Ivinghoe,

Three churches all in a row ;

These Manors Hampden did forego

For striking the Black Prince a blow, And glad he did escape so.

Probably this was from some hasty words with the renowned Black Prince, who was Hampden's neighbour, whilst the Prince was at Princes Risborough. As my visitor and myself were seated on this ancient camp, within three miles on our left I described Whiteleaf Cross, a noble relic of the Saxons, cut out on the hill side of one of the highest of the Chiltern range, the turf being removed, and thus showing the chalk beneath. The cross, of great size, stands upon a huge triangular base and is seen for many miles, being clearly visible at Oxford, nearly twenty miles distant. This remarkable work was formed by the Saxons about the year A.D. 57 O, to commemorate their last great victory over the Danes. On the low-lying lands at its base is 'Bledlow,' or Bloody Plain, which adjoins Horsenden, the residence of Horsa, the son of IVoden, and whose son 'Wiglif' commanded the Saxons; no doubt 'Whiteleaf' is a corruption of this name. Looking ahead is Dinton, the residence of Simon Mayne, the regicide in the time of Charles I., and adjoining is the village of 


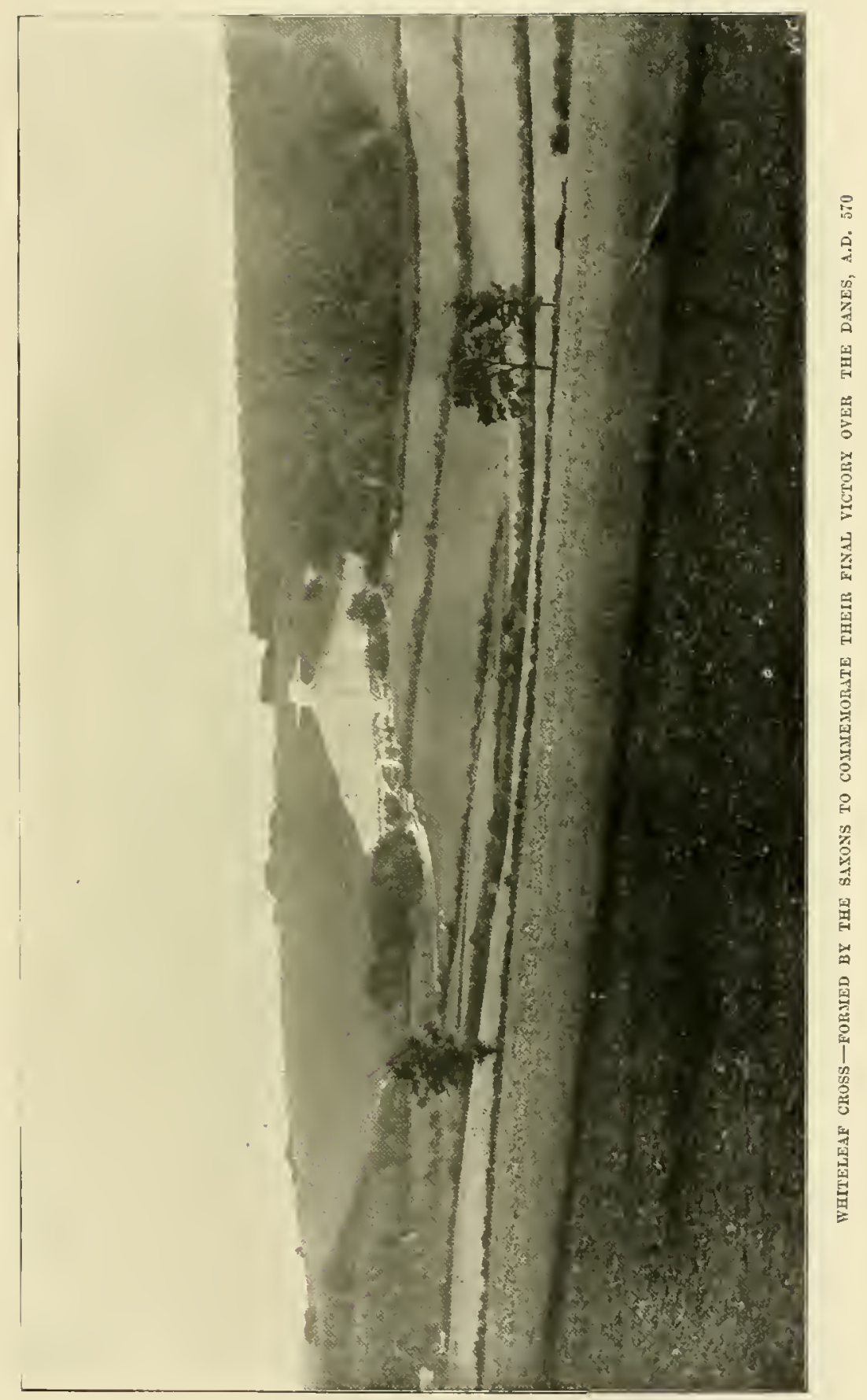



Hartwell, for seven years the home of Louis XVIII. and his Court after their escape from France under the first Napoleon. If this central part of Bucks is historical, so is the northern part, as it contains the town of Buckingham, which gives its name to the county ; but it appears that it never attained to the dignity of the county town, Aylesbury from time immemorial had always that honour. Near to the town is Stowe, the seat for generations of the Grenvilles, Dukes of Buckingham (and now the residence of the Duc d'Orleans and other members of the royal family of France), with Whaddon Chase, a noted stronghold of the ancient Britons when Julius Casar invaded the country 55 B.C. Yet in the south it is equally to be noticed, containing as it does the historic College of Eton, founded by King Henry III.

The county here is bounded by the River Thames-full as it is of history, with 'Danesfield,' near Great Marlow, where are the remains of a very perfect Danish camp. Nor must the village of Penn be forgotten-the home of the Penns-who founded Pennsylvania, in the United States of America. In this county poetry is nobly represented -by the residence of John Milton, who wrote 'Paradise Lost,' at Chalfont St. Giles; Hall Barn, the home of the courtly Waller in the reign of Charles II., now the residence of Sir Edward Lawson, Bart. ; Gray, with his elegy of the country churchyard, at Stoke Poges; Cowper, of Olney; and it is confidently believed that glorious Will 
Shakespeare, whilst on his journey from Stratfordon-Avon to London, when passing through Grendon Underwood, a village on the road from Bicester to Aylesbury, drew his picture of boorish life in the 'Midsummer Night's Dream' of 'Bottom the 'Veaver' and his companions from sojourners in a village ale-house. Adjoining this village is Ludgershall, where Wycliffe, one of the earliest champions of the Reformation, was vicar, and near to which is the little town of Brill, where King John had a palace, from whence he could hunt at his Manor of Boarstall and the forest of Bernewood. Thus it may well be called the historic county of Bucks.

I have had many opportunities, from a long residence in this county, of searching various records not only typical of the habits and customs of the people of the district, but of others. I think it may interest many people to be reminded of these events and celebrities of a bygone age, and give them some idea of rural life in our dear old country.

In Green's admirable book on 'The Making of England,' he says, 'It was by IVallingford, or the Ford of the "Whealtas," or Welshmen, as the conquerors called it, that the West Saxons must have passed the Thames in the year $57 \mathrm{I}$. Their leader was "Cuthwulf." There was one battle only of which we have record. Cuthbert's raid had carried him from WVallingford to the "Icknield Way," along the western slopes of the Chilterns, as far as Bedford, before the forces of the "Four Towns" 
LEAGUE OF THE FOUR TOWNS 9

could gather news of the foray, and an engagement took place, when the victory fell, as of old, to the Freebooters; and the success of Cuthwulf's men was followed by the ruin of the "League of the Four Towns."

'As one looks westward from the Chilterns, nowa-days, over Aylesbury Vale, the district of the "Four Towns" which formed the league consisted of Eynsham, Bensington, Aylesbury, and Lenborough, now a small hamlet near Buckingham. This lies stretched before you as far as Brill. Then, as now, the country was fertile and well peopled. A stream, the Thame, runs through Aylesbury, a town crowned with a church, or "Eglwys"- to which it probably owes its English name. A line close by the town of Thame, marks the present shire line of Bucks and Oxon, and marked the boundary of Aylesbury, and of that ruled by Bensington. The district of Lenborough lay along the Ouse, probably to Olney, and bounded by the territories of Towcester and Aylesbury. It was from the south that the West Saxons struck the country of the "Four Towns." They fought their way along the range of the Chilterns to Bedford and there halted.' Brown Willis, the antiquary, says that Whiteleaf Cross is a corruption of 'IVhite Cliff' Cross, but investigations have proved that it is from the Saxon chief 'Wiglife,' the grandson of Woden, and father of Hengist, who commanded the Saxons in a great battle fought at the foot of the hill, over the remaining portion of the Britons, who 
still held that part of the country. It is a great height, and the cross rises from a large triangle, and covers a great many acres of ground; it can be plainly seen at Oxford and other places, more than thirty miles distant. The cross and hill, by Act of Parliament, are declared public property, and it is occasionally scoured at the expense of the Lord of the Manor.

'Wayland Smith'-the god of smiths-and builder of Wayland Smith's cave, was brother of ' Egil,' who was equal to Thor-the god of battles -and from whom is 'Agilsbireg,' or Aylesbury. Agil was god of the sky, but in later days he was sunk into a darker and terrible deity. The corruptions of some words are curious and amusing. Close to the Icknield Way-the Via Iceni-is the 'World's End.' This is the Wold's end, where the wolds or hills merge into the valley. The town of Wendover is the 'wend or wind' over the hills; but still more interesting are the adjoining villages of the 'Kimbles,' the residence of 'Cymbeline' or 'Kymbeline' (Shakespeare's 'Cymbeline'), King of Britain, 500 years before the Saxons, who was king when Julius Casar invaded Britain 55 в.с.

Whilst alluding to Aylesbury, I don't think it is generally known that the unfortunate Queen Anne Boleyn was often called 'The Fair Maid of Aylesbury.' Her father, Sir Thomas Boleyn, became Earl of Wiltshire; he inherited the Manor of Aylesbury through his mother, who was a daughter of Thomas Boteler. The Earl sold the 


\section{THE FAIR MAID OF AYLESBURY II}

manor to Lord Chief Justice Baldwin. The cause of his selling the manor was, he says in a letter to Thomas, Lord Bramwell: "The truth is, that when I married my wife I had but fifty pounds a year for me and my wife as long as my father lived, and yet she brought me a child every year.' A writer of eminence says: 'This fair maid of Aylesbury, is described as being of that singular beauty and tendernesse that her parents took all care possible of her education. Therefore, besides the ordinary parts of virtuous instructions, wherewith she was liberally brought up, they gave her teachers in playing on musical instruments, singing, and dancing, inasmuch that when she composed her hands to play and her voice to sing, it was joined with that sweetness of countenance that three harmonies concurred. Likewise, when she danced, her rare proportions varied themselves into all the graces that belong either to rest or motion.' These accomplishments, improved by the ease and selfpossession she had acquired at the Court of France, captured, but could not secure, the affections of the salacious Henry, who, having conceived a passion for Jane Seymour, caused the Queen to be tried for adultery. This abominable charge rested on no other ground than some slight indiscretions, which her 'simplicity had equally betrayed to commit and to avow.' No proof of innocence could avail, however, with the king; she was condemned to die, and she expired on the scaffold. In one of her affecting protestations, which she sent to her 
unfeeling persecutor, she thus expresses herself: - From a private station you have raised me to that of a countess, from a countess you have made me queen, and now you can raise me one step higherto be a saint in heaven.' Anne Boleyn, when in the plenitude of her power, was a distinguished promoter of the Reformation, and all Englishmen should never be allowed to forget, that she was the mother of that truly great Sovereign, Queen Elizabeth. 


\section{CHAP'TER II}

Turnpikes and their keepers-Origin of turnpike trusts-General rate of tolls-Mr. Weller's opinions of pike men-A turnpike letting'Pikers' and their methods-Sharp practice-Lessees of tollsFeasting after the fray-Management of roads.

Ti1E great changes which have taken place in almost every department in rural, and even in town, life during the past fifty years is a sufficient excuse for my touching upon certain customs that really affected the whole body politic. Amongst many of those changes none seemed to make so much alteration as the abolition of turnpike gates. The present generation know but little of what these obstructions were, and but few even of those living at the time of their existence knew their history and management. I am not quite certain that my description of their origin is strictly correct, but having had in my early youth and manhood many opportunities of studying this particular phase of the genus homo-I mean turnpike gatekeepers, or 'pikers,' as also of the lessees of the tolls, who held many of the 'trusts' as they were called-I am enabled to give a slight sketch of this department of road management, together with the origin of turnpike trusts, and the methods by which they 
were conducted. I have been informed of what was the origin of these trusts, viz. that when the landowners and other inhabitants of certain districts were desirous of improving the means of communication between the towns, villages, and their properties adjacent, they went for an Act of Parliament, or employed the powers of the general Turnpilie Act.

They agreed to make certain roads, hitherto entirely maintained by the parishes through which they ran, into more extended fields of operation, and the then existing parish roads were widened, straightened, and otherwise vastly improved.

A 'trust' was formed with a number of gentlemen, chiefly of owners of land in the vicinity, who were empowered to raise money, by loan, to improve these highways, and to erect gates or barriers across them at certain places, to enable authorised persons to collect tolls from the drivers of all carriages, horses, cattle, or other animals passing through them, for the formation and maintenance of the roads included in the said trust. In general, these tolls were annually let by a species of public auction to the highest bidders, who were accepted if they were prepared to adhere to the conditions submitted to them. The usual tolls throughout England and Vales were-for a horse passing through the gates, ridden or led, $1 \frac{1}{2} d$., but if drawing any vehicle $4 \frac{1}{2} d$., so that a gig or phaeton with one horse paid $4 \frac{1}{2} d$., and a carriage with a pair $g d$., and so on. The imposition fell with particular 
hardship on farmers, and became a tax on their trade, as when sending their corn or other produce, with waggon and four horses, they paid is. $6 d$. or $2 s .3 d$. in some instances; often going through two gates in the space of eight or ten miles, they would thus have to pay $3 s$. or $4 s .6 d$, and, in some instances, so cxacting were the lessees, that if the same waggon which had conveyed corn or other produce to market brought back coal, oil-cake, or other feeding stuffs, they were expected to pay the same amount over again. Cattle, when passing through, paid so much per score-about Iod.-sheep and pigs rather less. There were also severely heavy penalties for waggons and carts carrying over a ton of goods of farm or other produce, if the wheels of the vehicle were under a specified width. Thus it became the custom to have broad-wheeled carts and waggons to save the extra toll. When a toll was paid it freed the payer up to twelve o'clock the same night; he could go through the gate as often as he pleased, but woe betide the gaily disposed individual if he had stayed at a friend's house, or had driven the ladies to an evening's entertainment or to a ball, if he waited till the early hours of the morning, or one single minute after the clock struck twelve; the gatekeeper was down upon him, and he had to fork out an extra toll, seeing that he had entered into another day. But the most intolerable nuisance of the turnpike was, that soon after twilight had set in, you had to wait in the rain, wind, or snow till the 'piker' opened his gate, 
and his operations were invariably conducted at a snail's pace. He then sauntered indoors to get change, whilst you underwent all the miseries of delay and consequent loss of temper. If at night, often as early as nine o'clock, you had to bang the door of the gatehouse till the man got up-generally in his night shirt, and an old coat thrown over him, and often with a tasselled night-cap for headgear. He then had to unlock the gate, and throw, or rather deliberately push it open to let you pass through. These gatekeepers rarely remained at the same gate more than a year or two at a time, as the tolls were often taken by different persons at the annual letting, and sometimes the lessees themselves came to reside at the houses attached to the gates, or put their sons or relatives in. In some instances they were extremely agreeable, nice people, but oftener they were sour, uncivil fellows, who seemed to delight in making themselves obnoxious to travellers. Dickens makes the elder Weller say that 'They're all on 'em men as has met with some disappintment in life, consequence of vich they retires from the world, and shuts themselves up in pikes, partly with the view of being solitary, and partly to rewenge themselves on mankind by takin' tolls. If they was gen'lm'n you'd call 'em misanthropes, but as it is, they only takes to pike-lieepin'.'

The distances from one turnpike gate to another varied very much, but generally the stopping-places were about eight to ten miles apart. In some places, as, for instance, my native town of Aylesbury the 


\section{INJURIOUS EFFECTS OF TURNPIKES I7}

place was literally hemmed in like a fortified city, not even an outlet to exercise a horse without paying a toll. There were seven different turnpike trusts to maintain in relation to the town. The funds collected from the gates were paid into the treasurer's hands of each trust, and the roads were repaired from them. It will be observed that a large amount was absorbed in paying lawyers, who were gencrally appointed to the posts of treasurers and clerks to the trustees, and also to surveyors. There were seven sets of officials for all these trusts, whereas one would have been sufficient. In many instances the interests on the loans had been umpaid for many years. I myself knew of several trusts where the interest had been in arrear for more than twenty-five years. After those leeches of officials had sucked in their salaries, there was but little over 50 per cent. of the takings left for the actual repair and maintenance of the roads. The lessees also expected to get a fair profit on their outlay, and the collectors received from 20s. to $25 \mathrm{~s}$. per week, which made a great inroad in to the receipts from the tolls. At last, owing to the introduction of railways, the funds for which the gates were let were so crippled, that by degrees one trust after the other expired, in most instances considerable loss being experienced by the original bondholders, who had found the money for the construction of the roads. In many cases alrcady printed as above, the holders were glad to get anything back; and I have heard that the average amount repaid to the 
bondholders throughout the country when the trusts were abolished was not more than $4 s$. or $5 s$. in the pound.

In giving this imperfect sketch of the establishment of turnpike trusts, I cannot forbear adding some slight account of the method of letting the tolls. The trustees, who were mostly country gentlemen of the district, forgathered at the principal inn in the county town in considerable numbers, and the whole place being en fîte, there was an assembly of as strange a collection of humanity as could well be got together. It was usual for the trustees to give a guinea for each gate let to be expended in refreshments, and as generally there were six or eight gates, there would be that number of guineas spent amongst about forty or fifty 'pikers,' as they were called, who attended, but only about six or seven of these would be bidders and lessees; these were men of capital, who rarely collected their own tolls. Those who witnessed these meetings called them the 'Whispering Society,' as the company scattered about the inn yard in groups of three, five, or more, were in full conclave, all in whispers; one would run off and whisper to another group and return again, when they would be approached by another envoy, whilst circulating rapidly amongst them was one of the bon $\hat{a}$ fide bidders, evidently making terms with several threatening opponents, and promising from 1 . to 5 l. to the recipient who refrained from bidding. At the appointed time a rush was made to the auction room, where the 
trustees, with their clerks, treasurers, surveyors, and other officers, were assembled. After the conditions were read the letting commenced, but it sometimes happened that the whispering had been so effective that not a single offer was made, to the astonishment of the trustees, who had not seen the Machiavellian mancuvres that had been going on for more than an hour elsewhere. As no biddings were made, it was then announced that the upset price was, say, zool. for each gate, and that unless that sum was obtained, the gates would be withdrawn and the trustees would put in their own collectors and farm the gates themselves. When the sum was announced a general groan of horror went round, and the trustees were told that the offer was so outrageous it could not be listened to ; that the last two years the gates had not produced more than $180 l$. to $190 l$., and the lessees had lost all their wages and expenses, but if they would listen to reason a tenant could be found at $15 \mathrm{ol}$. Suddenly some stranger to the 'pikers,' who had been unobserved by them, would bid I $\mathrm{Sol}$, at which there would be a burst of indignation and an outbreak of insulting by-play. 'Was that your bid, Jem?' one would exclaim. 'No,' another would remark; 'I ain't such a d__ d fool as that'; whereupon one of the body would spring 5l., and after a pause the stranger would top it with a bid of 1 col., when a gentleman of the Hebrew race, highly adorned with grold watch-chain and rings, and dressed in extra fashionable clothes, would rap the floor and hold 
a ventriloquial conversation with an imaginary partisan down in the cellar, calling his attention to the lunatic who had just come out of the asylum, and was bidding for this gate, suggesting that his keeper should be sent for. All this amid shouts of laughter, and the chairman of the trustees calling 'order.' After a long silence another 5l. would be advanced, when the stranger would immediately cap it by saying he would give the reserve. Great consternation would follow, and then you would hear the old lessee, who declared he had lost so much by taking the gates for the last two years, say that it had been a good hay and corn harvest, and that the steeplechases would come off in the year, and risk it by giving another $5 \%$, and make it $205 \%$. This recollection of an oft-repeated scene may be accepted as a fair specimen of a gate letting. All the whispering which had taken place beforehand represented an endeavour to buy off every dangerous opponent. Many persons came down from London and elsewhere, under pretence of taking the gates, who earned a sovereign or even $3 l$. as payment for the day's work from the lessee, who had probably held the gates for the past two or three years and was reluctant to lose them. The business of contracting to take turnpikes was in many instances an immensely expensive one. The gentleman who took most of the gates in Bucks and some of the adjoining counties was a Mr. Tongue, living at Nanchester, and it was estimated that he had 
upwards of 50,000/. annually embarked in gate holding. He retained a regular staff of collectors, who moved about from one part of the country to another, as his confidential servants. It should be observed that the stranger (in my typical scene at a sale) who had been bidding was put up by the trustees as an imaginary lessee to prevent such machinations as those which the Whispering Society had arranged. Following the letting came the dinner and the carouse, at which, it is needless to remark, the money of the trustees was rapidly expended. It was amusing to watch the advent of the cigars after the dinner. Young aspirants to smoking honours would station themselves behind the door of the dining-room; when the waiters brought the cigars in by a dozen at a time in glass tumblers, a dash would be made, and before the choice Havannahs could be brought into the room they were appropriated-vulgo stolen-' convey the wise it call'-and pocketed by the snatchers. The lessee generally put half a dozen port and sherry on the table, but took care to retain a couple of bottles for the consumption privately of himself and personal friends. All this is now abolished! The old turnpike gates are gone with the 'pikers'! No more exciting scenes on the road to Gretna by happy, but fearful couples; no more delays by stubborn pikers, already suborned to delay the pursuers by failing to give change, so immortalised by Caldecott and the old yellow post-chaise. And now the maintenance and 


\section{$22 \quad$ RECORDS OF OLD TIMES}

repairs of the roads are thrown on the backs of the already overtaxed farmers, to be again transferred to the tender mercies of the modern county councils. "The old things have passed away and all things have become new.' Well may it be said, 'Tempora mutantur, et nos mutamur in illis.' 


\section{CHAPTER III}

Early recollections of posting-Post-horse duty-The old inns and posting-houses-Collection of the duty-Manners and customs of travellers who posted-Cost-Post-horse Farmers-Shillibeer, the well-known Undertaker-Abolition of the duty.

MANy recollections of my busy life crowd upon me but there are some which should not be forgotten, and are singular records of bygone times. Some years ago the general public travelled but little; there were, in fact, few opportunities to go even from one neighbouring town or village to another. It is, indeed, marvellous to me how business and pleasure were carried on in my boyhood. I knew well how the nobility and gentry moved about the country, namely, by post-horses. And this brings to my memory what 'posting' in those days really was, and how few there are now living who understand it.

The period of 'Pickwick' was not only that of 'pikes' and 'pike-keepers,' but it was the palmy days of posting. Posting-houses and post-horses, with the system of travelling by the turnpike road which flourished in my youth, tempt me to again draw upon my recollections. A posting chapter follows naturally upon one devoted to toll-gates and toll-keepers. 


\section{RECORDS OF OLD TIMES}

The principal innkeepers in the town considered it a distinction to be enabled to place upon their sign-boards the words 'Posting-House,' such as the White Hart Inn and 'Posting-House.' The intimation was to the effect that not only horses could be provided to forward travellers onwards, but that accommodation could be offered for a party of travellers, servants included, for the night. It was, therefore, only the leading inns which could rank as posting-houses. A heavy tax was paid to Government, called the post-horse duty, and the manner in which it was levied, paid, and collected, was so extraordinary that it can scarcely be credited in the present day. It was impossible that this tax could be properly collected without the assistance of the turnpilse gates, and it was not for some years after the duty was repealed that these road obstructions were abolished. Had they been destroyed earlier the post-horse duty must have gone with them. The duty was charged at $1 \frac{1}{2} d$. per horse per mile, but as in the posting days few people travelled with less than a pair of horses, the one-horse fly not having then been invented, at least four-fifths of the travelling was performed in the owner's private carriage; a pair or four horses being used, according to the size of the carriage and the number of the passengers, and generally by the social rank of the traveller. When a carriage pulled up at the door of the inn a shout was heard of 'First turn out!' The ostler and all the household, generally with the proprictor at their head, 
were immediately alive to the occasion. As one pair of horses was always kept ready harnessed and saddled in the stable throughout the day, until racking-up and feeding time at night, ready for every emergency, no time was lost, the post-boy being already booted and spurred, the driver almost invariably riding, or, to use the prevalent term, 'bumped the saddle.' The traveller, who was probably coming from or going to the metropolis, gave out the place he was bound for, asked the number of miles, say to Buckingham or Bicester (seventeen miles), and as the charge, including duty, for a pair of horses was $15.6 d$. a mile, the amount would be $1 l$. $5 s$. $6 d$., which was generally paid before starting. Sixpence was given to the ostler, and $3 \%$. per mile for the post-boy; and as there were three turnpike gates on the road, the cost at $9 d$. each was 2s. $3^{d}$., with i is. for an occasional bait or stoppage, it brought the amount as near as possible to $2 s$. per mile. The pace, including stoppage, changing horses, \&c., was about eight to nine miles per hour. Thus, if the travellers left London, sixty miles distant, at ten o'clock in the morning, with an hour for luncheon en route, by six o'clock they were ready for dinner : they rarely travelled beyond that hour, and then made themselves comfortable for the night. It will therefore be observed what an expensive and difficult thing it became to move an establishment, with children and servants, about the country; and that when a family left their house in the early spring for the London season, there was but little induce. 
ment for them to return home till the middle or end of July.

The 'riding' post-horse was generally a good specimen of a fairly useful weight-carrying hunter of the present day, trotting well, with head and tail up, at about ten miles an hour, and capable of drawing half a ton behind him, with the boy, about eight stone, on his back in addition. He usually cost about 30l. As a riding horse he generally lasted about four or five years, when he became rather unsafe to ride, and was called a 'hand horse,' from being placed on the offside of the pole of the carriage, and was but rarely ridden afterwards. Throughout the kingdom there were almost invariably two rival posting-houses in every important town, at one establishment the post-boys riding in blue jackets, the other in yellow, with black or white top hats, drab cloth or leather breeches, and top boots. The blue and yellow jackets had their own line, and ran to the same houses of each colour throughout the country. I have heard a gentleman say that he had travelled from York to London, beginning with a blue jacket, without deviation the whole distance, never having got on the yellow line. The riders, who were called post-boys, were often very old fellows. 'Old Humphrey' lived with my father, and 'drove post' for over forty-five years, and it was never known how old he was. (According to Sam Weller, nobody ever saw a dead post-boy.)

The post-horse duty was collected in this wise. When the horses at each stage were being changed. 
the proprietor of the inn made out the ticket, as it was called, a number of which were strung up in the bar. They were supplied by the Government, and bore the royal arms. They were in blank for the date-the place from which the horses started-the place of destination-the number of miles, and at the foot the name of the driver was inserted. These tickets were printed on stiff paper, about the size of a modern postcard. The blanks were filled in and the ticket given to the post-boy when he had mounted the saddle, a heavy fine being inflicted on the postmaster if he neglected this part of his duty. At the first turnpike gate through which the carriage passed, the boy was bound to deliver the ticket, at the risk of another heavy fine. It would sometimes happen that the delivery was omitted, but the postboy could, of course, remedy the omission on his return. If, however, the gatekeeper was cantankerous, he might refuse the ticket, and thereupon a heavy fine was incurred. Each morning the postmaster was bound to fill up the official duty sheet, with every hiring of the previous day, showing the number of miles and the amount payable. This was a great nuisance, and if any error, however trifling, occurred, a fine of double duty would be inflicted.

England and Scotland were divided into districts comprising three or four counties, which were let, or farmed, out to different contractors, who were called 'Post-horse Farmers.' Messrs. Levi and others of the Hebrew race were generally the farmers who 
employed agents to call at the turnpikes in their districts and collect the tickets. These agents waited on the postmaster every month, who compared and checked off the entries with the tickets collected, and when the amount was ascertained the money was paid. These men were harpies who exacted the uttermost farthing, and if inadvertently a date was wrong, or even a penny omitted, cumulative fines were inposed. I remember a monstrous instance of this form of exaction. Through a misapprehension of the law, a postmaster had entered two pence short in one of his sheets, and this had been carried on about eight times, during a period of six months, the total amount omitted being one shilling and fourpence. Well, fines were inflicted amounting to nearly I,500l. ! After considerable litigation the action was compromised for $50 l$. The grossest tyranny was practised, the Act of Parliament being strained to the utmost. Eventually a meeting of the postmasters of England and Scotland (Ireland being exempt, which I could never understand) was held in the Freemasons' Hall, London, presided over by Mr. Shillibeer, the famous Undertaker, and the first mant to introduce the omnibus into England. He had been a great sufferer under the iniquitous system. A deputation waited on Mr. Disraeli, the Chancellor of the Exchequer in Lord Derby's first administration, who promised to assist in destroying this last remains of 'farming' the revenue, but the Ministry suddenly came to an end. 
The following year, however, Mr. Gladstone abolished the post-horse duty, substituting therefor an annual tax on all horses let for hire, and on postcarriages, in lieu of it. A few years afterwards Sir Stafford Northcote repealed the duties on horses, and thus that most obnoxious tax upon horses and posting disappeared for ever. This duty, I believe, had brought into the Exchequer about $500,000 /$. per annum, but the amount exacted from the public was considerably more, as the cost of collection was enormous, and the profits made by the farmers correspondingly large. The postmasters opened a subscription for Mr. Shillibeer, and presented him with a handsome service of plate, and a cheque for Sool., and so ended the posthorse duties. I have written this statement that men of the present day may know what certain trades had to put up with, in the memory of many still living. The introduction of railways gave the coup de grâce to the old posting trade. 


\section{CHAPTER IV}

Eton Montem-Customs-Their origin-Collecting salt-Waving the flag on the Mount ad Ifontem - Salt bearers-The Windmill InnMr. Botham-The traffic on the Great Western road-RoyaltyThe Playing Fields-Dr. Goodall-Dinton.

IN my numerous researches into old country customs, I have been tempted to record many stories, which tend to illustrate the habits and customs of the English people in olden times Naturally I have been better able to collect materials from my native county of Bucks than elsewhere, but they afford types of other parts of rural England. Some are of Parliamentary history, others parochial, whilst amongst them are notes referring to the glorious public school-1 mean 'Eton College.' I find that the first stone of the chapel was laid on July 3,1441, and writs were issued for assembling together workmen for the speedy completion of the building. The school owed its foundation to Henry VI., and it was evidently to instruct in grammar those who were to take Holy Orders. As old Fuller remarks, 'It was high time some school should be founded, considering how low grammar learning then ran in the land.' At times there was 
considerable trouble as to the proper foundation of the college. At the time of Henry VIII. the college was threatened with dissolution, but the death of the king prevented it, and its destruction was specially excepted in the Act for the dissolution of colleges and chantries in the reign of Edward VI. Amongst the old customs of Eton College was that of hunting the Ram. In some curious manuscripts in the British Museum it is stated that the custom obtained in the Manor of Wrotham, in Norfolk, which belongs to the college, where the Lord of the Manor, after harvest, gave half an acre of barley and a ram to the tenants. If the tenants caught the ram it became theirs; if they failed to do so, it belonged to the Lord again. As late as 1747 the collegers hunted the Ram. Perhaps the most interesting custom was the celebration of 'Montem,' the last of which it was my privilege to have attended more than fifty years ago. The procedure of the Montem was, according to 'Brand's Popular Antiquities,' that on Whit Tuesday a procession was made every third year to a tumulus or mound close to the turnpike road, and nearly opposite to the great 'Windmill Inn,' which I remember well, as a large oldfashioned hostelry, with immense stabling and yards for more than a hundred horses. When I was there it was kept by Mr. Botham, who horsed some of the coaches on the great Bath road, and kept upwards of twenty pairs of post-horses. This assemblage was called the 'Montem,' from the school procession going to the tumulus or 'ad Montem.' The village 
was named 'Salt Hill,' from the collection of 'salt,' as it was called, which was money collected from all who were present, or who travelled along the high road that day. Royalty often attended the meeting. The late Mr. Montagu Williams, Q.C., who was an Etonian, and proud of it, as they all are, or ought to be, says, in his 'Leaves of a Life,' that "Royalty itself was not free from the tax. Two "salt-bearers" were stationed on Windsor Bridge, and when the Queen drove down the hill-and she never missed a Montem-the elder of the two stepped forward, stopped the carriage, and, taking off his hat, with the words, "Salt, your Majesty, salt," placed under contribution the highest and noblest lady in the land.' The gentlemen students of the school went in military procession from Eton to Salt Hill-those on the higher forms in scarlet military jackets, white trousers, and plumed cocked hats, wearing swords; those on the lower forms in the present costume of short jackets, laydown collars, and top hats. On arriving at Salt Hill, the ensign, who was the lieutenant, or second boy in the school, ascended the Mount, waved and flourished a flag, either the Union Jack or Royal Standard, whilst the boys marched round in procession. A short Latin service was then read by the chaplain and his clerks. The salt-bearers were busy in collecting the salt. These officials were leading students, and were dressed in splendid medixval costumes of great beauty, velvet or satin cloaks, trunk hose, gorgeous hats with plumes of 
feathers ; they went in pairs, carrying very beautiful and richly embroidered bags for collecting 'salt,' holding them up to the travellers and wayfarers passing along the roads. There were about twelve salt-bearers, and, holding up their gorgeous bags, cried 'Salt, salt!' The amount when collected was brought to the headmaster's house, counted, and was then invested to endow the first boy in this school, and thus pay his expenses to King's College, Cambridge.

The year when I attended, nearly I,000/. was collected. This was a grand contribution, the boy being a very popular scholar. The boys, numbering over Soo, were regaled at the ' Windmill'; after dinner those in military attire with scarlet coats, white trousers, cocked hats and feathers, drew their swords, entered the gardens of the inn, and ruthlessly slashed and cut down all the shrubs and flowers. Mr. Botham was most indignant at this wanton destruction of his gardens, but it was pleaded by the depredators, that the motto 'Mos pro lege' was sufficient to excuse them. In the end the authorities had to pay nearly 100 . for this serious clamage, and the outrage was one of the reasons given for abolishing the 'Montem.' It was finally abandoned about I 844 . In the evening of this celebration the playing fields near the college were filled with the beauty and fashion of the families whose sons were at Eton and of the neighbourhood, promenading to the strains of military bands, and a grand display of fireworks brought the 'Nonten ' to 
an end. Thus concluded one of the most delightful customs handed down to us from the middle ages. When the list of English worthies in learning, politics, and war is scanned, a large majority will be found to have had their educational career commenced at Eton. Well might it be recorded that the Duke of Wellington, in allusion to the great athletic feats performed by Eton boys, and by the inculcating to them of those noble principles of honour, patriotism, and self-reliance, taught there, say, "The battle of IVaterloo was won on the playing fields of Eton.''Floreat Etona.'

Whilst writing of the Eton Montem, the dear old provost, Dr. Goodall, is brought to my recollection. In my boyhood I well remember his genial, benevolent countenance, often lit up with a humorous smile, when he changed horses at my father's house at Aylesbury, on his way from Eton to his brother, who resided at Dinton Hall, which was about five miles from the town and three from Hartwell. I was always glad to see the Provost, as he had generally some kind remark to make, adorned with some simple Latin quotation, as it struck me, to discover if I kept up my school classics, which fortunately I did. Doctor Goodall's brother was vicar of Dinton. He was a very aged man, who, many years before, had married a daughter of Sir John Van Hattem, ${ }^{1}$ who was a member of the 'Hell-Fire Club,' with the Earl of Chesterfield, who hat a fine house at Eythrope, about three miles

1 N.B.-He came orcr with, and was Naval A.D.C. to William and Nary. 


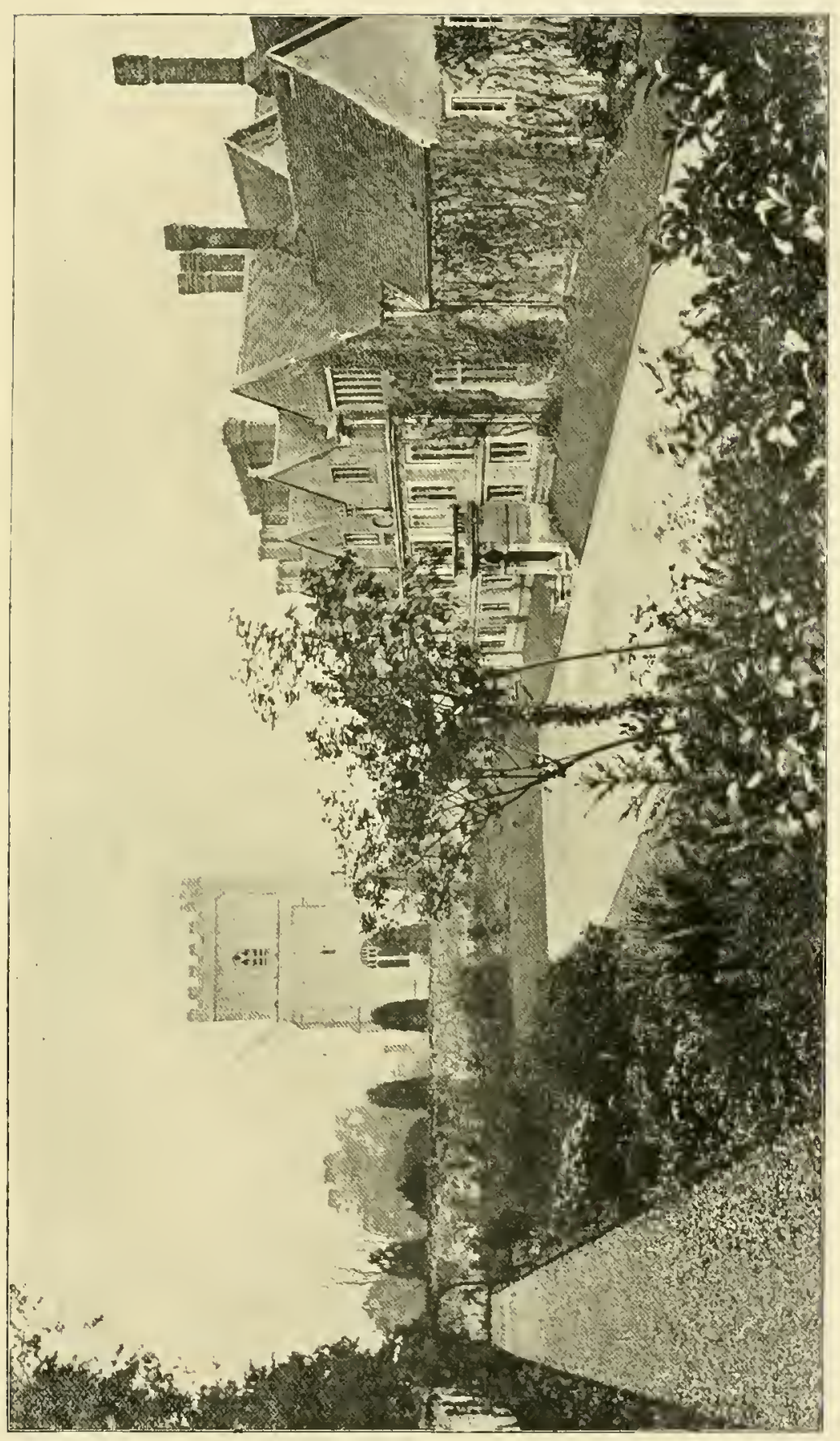

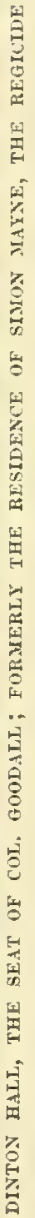





\section{DINTON HALL AND SIMON MAYNE 35}

from his hall. John Wilkes, the member of Parliament for Aylesbury, was a 'Hell-Fire' man ; in fact, all three were members of that terrible fraternity of Medmenliam Abbey notoriety. Sir John was the owner, and resided at that fine old hall, bequeathing it to his daughter, who married the Rev. Joseph Goodall, and thus the mansion came into the family, and is now inhabited by his grandson, Colonel Goodall, who married one of the Miss Lees of Hartwell; and thus it was that these two families became united. I well remember the Rev. Mr. Goodall and his venerable lady, although it is more than sixty years ago. Dinton Hall has historical associations. At one time it belonged to William of Wareham, Lord Chancellor and Archbishop of Canterbury, and his arms are still preserved in several of the painted windows. It was the residence of Simon Mayne, the Regicide, who was one of the signatories to the death warrant of the martyred King Charles I. He was member of Parliament for Aylesbury at that time, and was one of the excepted Regicides, yet was arraigned for high treason on October 16, 1660. Simon Mayne sat as member for Aylesbury through the whole of the Protectorate. He said, in his defence, that he was drawn into signing the King's death warrant. He was, however, sentenced to be imprisoned in the Tower, where he died the next year, and was buried at Dinton. His colleague in the representation of Aylesbury was another Regicide, one Thomas Scott. He was originally a brewer, and afterwards an attorney in the town. He 
was excepted from the Act of Indemnity, and always exulted in the part he took in the death of the King. He was executed at Charing Cross. At the scaffold he said, 'Gentlemen, I stand here a spectacle to God, and to angels, and to men. To you I have something to say: In the beginning of these troubles I, with many others, was dissatisfied; I saw the dangers and the approach of Popery in a great measure coming on us ; I saw___' The Sheriff and Under-sheriff interrupted hin. "Tis hard that an Englishman hath not liberty to speak, and that you will not hear the last words of a dying man.' He then prayed to God, and thanked Him that he had engaged in a cause not to be repented of. On his prayer being ended, he was cast off the ladder. Colonel Jones and Colonel John Wood were also executed at the same time; they were hanged, drawn and quartered.

I find it recorded that after the battle of Naseby Cromwell went to Dinton Hall on his return, probably on the route to Chequers Court, near Ellesborough, the residence of his daughter, Mrs. Russell, and that he left behind him his sword as a property, not to any particular family, but to the mansion of Dinton for ever. Colonel Goodall writes me 'that the sword is still in his possession. It is a beautifully balanced weapon, with the name of the celebrated maker, "Andrea Ferrara," on both sides of the blade.' Cromwell most likely went also to Dinton to visit his friend Simon Mayne, at that time owner of the Hall in the same parish. Waldridge was then inhabited by Sir Richard Ingoldsby, 
who had married Elizabeth, daughter of Sir Oliver Cromwell of Hinchinbroke, in the County of Huntingdon, a cousin of the Protector. Sir Richard was buried at Dinton.

Whilst writing of Dinton Hall I cannot refrain from mentioning the so-called Dinton hermit. He was one John Bigg. In the earlier part of his life he was clerk to Simon Mayne, when the latter was Justice of the Peace. This hermit abode in a cave underground, in the parish, and for several years wandered about the neighbourhood receiving alms and food from the benevolent. He never changed his clothes, and his method of mending them was by sewing fresh pieces of cloth or leather over the decayed part. I have seen one of his shoes at Dinton Hall, and I believe it is still in Colonel Goodall's possession. This shoe had been so often mended by pieces of leather nailid together, that it was tenfold its original thickness. The fellow shoe is now in the Bodleian Library, at Oxford. John Bigg died on April 2, I696, and was buried at Dinton on April 4. It has often been alleged that he was the executioner who beheaded the King, Charles I.

In mentioning the abolition of the Eton Montem it is necessary to call attention to the fact of the opening of the Great Western Railway at that time, which had driven the coaches off the Great Bath Road, as also the carriages of the nobility and gentry, thus making the collection of 'salt' a serious diminution, and rendering it scarcely worth while to go to so great an expense for the service. 


\section{CHAPTER V}

Early recollections of the I)erby-Lord Berners and Phosphorus in 1837-Caravan and Lord Suffield-Mly first Derby-Bloomsbury's year, $1839-\mathrm{Mly}$ costume-Heavy snowstorm on Oakapple Day, May 29-Opening of the London and South-Western Railway from Nine Elms-'No more trains !'-Cab to Kingston-A borrowed ride on a post-chaise-.' Whip behind!'-A mad rush, but in time to see the finish --Amato's victory - From Aylesbury to Epsom on horseback in $184 \mathrm{I}$-Well-named Little 'Wonder': won with 40 to I against him--The Queen and Prince Albert presentRunning Rein-Daniel O'Rourke-My folly.

Many writers have described their visits to Epsom Downs on the day of the Derby, the race par excellence of the sporting world. Some of my own Derby Day adventures and experiences I am tempted to recapitulate. I had from my schoolboy days delighted in horse racing, and I remember in very early life hearing of the 'dead heat' for the Derby between Cadland and The Colonel, which ended in the run off, after an exciting race, in the triumph of the former. That event was in i $\$ 2 S$. The competing jockeys were J. Robinson and W. Scott. The field numbered fifteen, and one of the lot fell-I forget which-his rider being seriously injured. The Colonel and Cadland started nearly equal favourites, the latter, as winner of the Two Thousand, having a strong public following. It being determined that 'the decider' should be run 
off after the race for the Durdans Stakes, betting began anew, and left off with 6 to 5 on The Colonel. Cadland made the pace to the chains, when The Colonel got up, but in spite of a tremendous finish was beaten by half a length. No third horse was placed by the judge. This was followed some years after by a repetition in my eager hearing of the story of Plenipotentiary's race, called for brevity 'Plenipo,' also by Bay Middleton, one of the best horses Lord Jersey ever bred. The Chifneys declared him to be a $15 \mathrm{lb}$. better horse than ever Priam had been. He won in a canter by a couple of lengths. The recital of these famous victories naturally inspired me with a great desire to see this national event. In the year 1837 I had heard of the exciting race, when the great favourite, great in size as well as fame, Caravan-the son of Camel-was beaten by Lord Berners' Phosphorus. It is stated that the trainer of the latter told his lordship, some days before the race, that the horse was lame and unfit to run; but Lord Berners, who was one of the most honourable men on the turf, declared that the public had backed the horse, and that he should run, 'if only on three legs.' It was related by those who saw the start, that Phosphorus was quite lame, but before reaching Tattenham Corner he was running perfectly sound, and despite of all the efforts of the rider of Caravan, he was cleverly beaten. His owner, Lord Suffield, lost a large sum of money on the race, and his estates became encumbered for many a long year after- 
wards. The betting was 40 to I against Phosphorus. George Borruw, the author of 'Lavengro,' said that of the three personages he always had a desire to see, the second was Lamplighter, the sire of Phosphorus, Lord Berners' winner of the Derby. The next year, I 839 , was a very memorable one to me, inasmuch as it was the first Derby I ever witnessed. It was remarkable as a sporting event, by being run on May 29, Oakapple Day, in so heavy a fall of snow as to render the colours of the riders almost invisible. Bloomsbury (a son of Mulatto) was the winner, and the race was remembered by me for many years, as I had taken great pains with my costume, a description of which may be given, as affording an idea of the dress of the times. In the present day it would be the height of caddishness to be seen in such lond habiliments, but I was then considered to be a smart lad, and I wore a pair of white duck trousers, strapped down over a pair of Wellington boots, an olive-brown, cut-away Newmarket coat, with gilt basket-buttons, and the breast looped together by a pair of the tusks of a fox, a buff cashmere waistcoat, and a resplendent blue satin full-sized stock, fastened by two gold pearl pins coupled together by a small chain. I had booked my place by a fourhorse coach, which started from the 'Swan with Two Necks' in Lad Lane, at a guinea fare there and back. We arrived safely on the course soon after one o'clock; the morning had been very fine, and the ride down most enjoyable. After lounging 


\section{THE DERBY IN A SNOWSTORM 4I}

about and seeing two races, I prepared for the event of the day, when, just before the start, an ominous black cloud overshadowed the course, and down came such a snowstorm as I had hardly ever witnessed in the depth of winter. I had obtained an excellent place at the ropes, not far from Tattenham Corner, and saw as much of the race as the snowstorm would permit, when I soon found my light summer clothing was too pervious to the melting snow, and before I could reach any shelter I was completely soaked through. As it happened, the coachman and my companions were mostly in the same wet state, and were glad to return. I arrived in a shivering state at my hostelry, the 'Old Bell,' Holborn, then one of the leading Inns in London, where I was only too glad to get between the blankets prior to enjoying my dinner, and, in dry clothes, a visit to Drury Lane Theatre. After the notorious 'Running Rein' case, statements were rife as to several other Derby wimners, and it was generally believed that Bloomsbury was a four-year-old. He did but little afterwards.

The year 1840 was noted as the first year that the London and South-IVestern Railway proposed to carry visitors to the great race. It was announced that the railway would carry passengers to Kingston from Vauxhall or Nine Elms, as the terminal station was then called, where four-horse coaches would be in readiness to convey passengers on to the course. The charge for tickets, issued three days previously, was one guinea, which also was to 
include the return to London wiâ Kingston. I went in a cab to Nine Elms at twelve o'clock, again in holiday costume, but not so outrageously loud as in the previous year, when, to my annoyance and disgust, I found a crowd of over a thousand persons, vastly indignant at beholding an announcement posted up that ' No more trains would start that day.' No provision had been made for a break down, and thus the people were left behind. The crowd was momentarily augmented, and, of course, I felt powerless to help myself in so great an assemblage. Suddenly I perceived a young gentleman arrive in a two-wheeled cab (Hansoms were not then invented) who was as disappointed and angry as myself. I proposed that if a bargain could be made with his cabman, I would join him as far as Kingston, where we were assured coaches would be waiting to convey us on to the course. We agreed to give 'Cabby' a sovereign to drive us to the town. The day was lovely and we were hopeful, but on arriving at 1.30 we found no coaches or other conveyances to carry us further. Here was a pretty fix for us to be in! However, I was young, hearty, and fleet of foot in those days, and, although my friend decided to go no further, I determined to run and walk towards the Downs, trusting to my luck to find some conveyance on the road. After running about a mile, I heard wheels behind me, and saw an old-fashioned yellow post-chaise, with post-boy in blue jacket and white silk top hat, riding with a pair of good trotting horses spanking along. 
Now, I thought to myself, is my chance. I got near to the centre of the road, when, just as the carriage passed me, I rushed forward and clutched hold of the springs behind, which assisted me greatly. A slight hill caused the horses to go somewhat slower, when I fancied I might make a desperate, but most dangerous, attempt to spring up, and place my feet on the hind axle-tree. This was protected by a spiked iron bar, yet I dexterously made an effort to place my toes somewhere between the spikes, and eventually succeeded. The horses dashed on in a dense cloud of dust, whilst I clung, like grim death, to the springs, and held on in my hazardous position. When we arrived at the town of Epsom, some wanton boys shouted 'Whip behind!' calling attention to my frantic efforts. As was common in such carriages at that time, there was a small circular window at the back of the chaise, which enabled the gentlemen inside to see me. They called to the post-boy to stop, and ordered me down. I had already performed that feat, and took off my hat, thanking them for my ride of over three miles. I then rushed off to the Downs. The Derby was timed for three o'clock, it was then about 2.40. I fortunately met a cab returning from the course, and told the driver I would give him five shillings if he drove me there in time to see the race. To this he agreed, when he dashed over the Downs, bumping along as hard as his horse could go, pulling up at the back of the stand whilst the crowd were shoutingr 
'They're off!' I pushed my head between some of the crowd, and distinctly saw the horses coming round Tattenham Corner, and, amidst the shouts of the mass of spectators, found that 'Amato' had won. I then discovered that I was in a most disreputable state, being smothered with a coating of clust, my coat was white, my face steaming with perspiration, grimed with road dust. I was too glad to steal away and get back to London as soon as possible, but I had gained my end, I had secn the Derby, and determined, if I lived another year, I would leave nothing to chance, and would ride my own horse to the race.

The next year's Derby was memorable as being won by a rank outsider, yet I enjoyed my visit immensely. I rode my nag from home the day before, to Gerrard's Cross, sleeping at the house of an old friend, a thorough sportsman and successful steeplechase rider. After an early breakfast we rode to Kingston to luncheon, and from thence steadily on to the course. At this time the horses started at 'The Warren,' which is some distance from the present place, where the field paraded and cantered before the 'start.' We were much pleased with all the runners, especially with the favourite, Launcelot, ridden by Bill Scott. My friend, who was an excellent judge of a horse, whilst commenting on the starters, pointed out a little compact, bright bay horse, asking me 'what I thought of him ?' I said, 'He's only a pony, and will never get up the hill.' He replied: 'That horse will win to-day. I never 
saw a horse sent to the post in such perfect condition and bloom in my life; and, unless I am much mistaken, he'll wear 'em all down if he gets a good start.' On examining him more closely, I began to think my friend was justified in his opinion. You could see your face in the brightness of his skin, and his muscles stood out like knots of iron, his sinews and feet were perfect, he had a sweet temper, walking and cantering like a gentleman. This was Little Wonder, belonging to W. Forth, who had another horse, a nameless one, in the race, known as the 'Solace colt,' which he intended to ride himself, placing Macdonald on Little Wonder, which warranted the public in putting their money on the Solace colt, who started at 20 to 1 , whilst odds of 40 to 1 were laid against his companion. Launcelot, the favourite, who was a beautiful colt, and in the best possible condition, stood at 5 to 2 against. The race is easily described, for as soon as they started Little Wonder galloped away, and when rounding Tattenham Corner forged ahead, and was never caught, Bill Scott striving his utmost to reach him with Launcelot, who was second. This was also a most noticeable Derby, as it was the only one at which her present Majesty ever attended. She was accompanied by Prince Albert, who had promised to present a gold-mounted whip to the rider of the winner. Macdonald was called up to the Royal Stand, and received the much coveted prize. He was considered to be a butcher on any horse he rode when necessary, but in this 
instance hard measures were unnecessary. It should be stated that I,ittle Wonder stood only I 4.3 hands high. Some years afterwards, when commenting on this race, ill-natured people always asserted that Little Wonder was not a four-year-old, but was a fiveyear-old! The horse had only appeared once before, and, I believe, only ran once or twice afterwards. For some years after I rode my horse to Kingston the night before the race, stopping once or twice on the road for refreshment; the distance was nearly fifty miles from Aylesbury. After the race I was accustomed to ride into London, enjoying a few days' stay there, and returning home by the end of the week. It is not generally known that at that time the Derby was run on the Thursday, and only changed to Wednesday when it was found to be very unfair to mares who ran for the 'Oaks' on Friday, which practically prevented them from running, without a day between the races; so that the authorities changed from Thursday to the Wednesday, thus giving a chance for a mare to run for the two events.

There are probably very many visitors to Epsom who could give their experiences of chances thrown away on races. Yet I cannot refrain from mentioning a very strange fatality, and, I may so term it, a silly refusal to avail myself of a really good 'tip' for this great race. Once, when at the Haymarket Theatre on the eve of the Derby, I left the auditorium and strolled into a bar on the opposite side of the street for my glass of 
bitter, when I was accosted by a friend whom I happened to know very well. This was no other than 'Charley Boyce,' the jockey. After some general conversation he asked me what horse I thought would win to-morrow. I said, 'Of course, the favourite, Hobbie Noble.' He replied: 'I can give you the greatest certainty possible, your horse can't win. If you will be guided by me, you will put $5 l$. on Daniel O'Rourke; you may depend upon it, he will be first past the post.' 'To this I demurred. He said, 'I might just as well go home with a hundred pounds in my pocket as not. You can get 20 or 25 to 1 about him, and if you won't have a fiver, have just one sovereign, as there are plenty of houses near here that will do it.' It should be noticed that at that period more than half the houses, whether public bars, hairdressers, tobacconists, confectioners, \&c., \&c., were all betting houses; and it was the existence of these places, which had sprung up all over London, that compelled the Legislature to pass the Act for suppression of list betting. I foolishly refused to take Charley's 'tip,' and retired to my friend's house at Roehampton, where I was staying. We had chartered an omnibus to take us on to the coursethere were twelve of us-and we agreed to have a draw, putting down Ios., viz.- $5 l$. for the first and Il. for the second. It was surprising to me that I drew Daniel O'Rourke! Such was my prejudice against the horse, that I sold him for ros., the amount I had ventured. The race has been so 
fully described that it is unnecessary to say more than that Daniel won easily enough, ridden by $\mathrm{W}$. Scott; an unknown horse, Barbarian, was second; Hobbie Noble third; and Chief Baron Nicholson fourth. This was, indeed, a sensational Derby, especially as to the second horse, who, if he had won, would have landed an unparalleled coup. I don't know if he ever was heard of in the ring, excepting at some hazardous chance of 50 or 100 to $I$. I heard that he arrived on the morning of the race by rail, was taken out of the truck, and led on to the course in all his dust and dishabille, after his long journey from Ireland. He was saddled, his jockey mounted, and was not even recognised, except by his owner and friends, and started as an unknown competitor. I saw him after the race, and thought him a splendid colt.

As I neglected winning my hundred pounds, I must recount my extraordinary luck and judgment afterwards in selecting a winner of this classic race. At one of the meetings of the Aristocratic Steeplechases over my farm at Aylesbury, after the Stewards' dinner, the conversation turned as to the Derby. This was about the middle of Narch, and I was asked who I thought would win that race. I replied 'West Australian,' when one of the 'Varsity' men present offered me $50 l$. to $4 l$. - I $2 \frac{1}{2}$ to I against hin, which $I$ at once accepted, when Captain $\mathrm{K}$ —_, who was present, said I was foolish, as he would lay me $60 l$. to $4 l$. . I 5 to 1 , which 1 booked, thus closing my little book for the race. The horse 
soon began to rise in the betting, and about a fortnight before the races he had advanced to 5 to $\mathrm{I}$. As I stood to win $\mathrm{i}$ iol. to $8 \%$, I therefore determined to make nuself safe, so with a sporting parson, who was an old friend of mine, I laid $40 \%$ to 8l. against the horse. I thus stood to win $70 \%$ to nothing. Needless to say West Australian won. I was so delighted that on the following Saturday, on seeing the reverend gentleman, I gladly gave him a cheque for $40 \%$ Such was my terrible luck that I have never, from that day to this, received my i 10 ., or a single farthing of it, so that instead of receiving my i $10 l$, my banking account was 40 . the less. I then determined never again to stake more than 5 \% on any race, and I have kept my word. 'Sic transit gloria nundi.'

lt may interest some of my readers to mention one or two singular circumstances which are not generally known on the 'Running Rein' case, when it was proved that the horse was a four-year-old, and, although he had won, the race was given to Colonel Peel's Orlando, who was second. The conspirators, led by Goodman Levi, and others of the Hebrew fraternity, had arranged to win with another four or perhaps five-year-old horse, named Leander, who they had backed heavily, when, on rounding Tattenham Corner, he was knocked over, and broke his thigh. The poor brute was killed, and the same evening was buried near the course. After the 'Running Rein' trial, and the jury had given the race against him, it was 
deemed advisable to exhume Leander, and so verify the reports about him, when, on his exhumation, it was discovered that his lower jaw had been sazen off and carried away! so that all proof of his age had been destroyed. I have been told that the conspirators had arranged that if the horse had won he was to have been sent off immediately after the race to Gravesend, where a steamer was in readiness to take him out to sea, to be there killed and thrown overboard, so as never to have been seen again; but the accident prevented the scheme from being carried out. 


\section{CHAPTER VI}

Recollections of the Cup Day at Ascot-My ride from home-The Queen, Prince Consort, and the Emperor of Russia: interesting conversation-The Countess of Albemarle's carriage - The Earl, Master of the Horse, wins with his son of Defence, beating AttilaDelight of the crowd-The Emperor's promise to present the Ascot Cup in future-Establishment of the Crsarewitch Stakes-The Defence colt called the 'Emperor' - Wins the vase the following year-Graceful act of the Earl : presents the vase to her Majesty the Queen, and the horse to the Czar-My next 'Ascot'-Deadheat between Buckstone and Tim Whiffler.

There is to me something fascinating in the recollection of a sporting event, which, from its especial singularity, has impressed itself on my mind; and although 1 have had some curious experiences of early Derbys, I believe that those I am about to relate of early Ascot Cup days are none the less pregnant with interest. The year I 843 , which was the next to that when Attila won the Derby, was made memorable by the visit of the Emperor of Russia, and, I think, the King of Saxony, with other illustrious personages, to the Queen and Prince Albert, and who attended at Ascot Heath to see the race for the Cup. An immense concourse of people attended. I rode my horse all the way from Aylesbury and back again the same night-a distance of seventy-five miles. I left home about 7 A.M., after a hearty breakfast, and 
arrived on the Heath a little after one o'clock, having baited at High $\mathrm{Wycombe}$, and I rode into my yard about twelve o'clock the same night, having stopped again for an hour at High Wycombe. After I had seen the finish of the two races preceding the Cup, like everyone else I was desirous of witnessing the struggle for the great event. The course was cleared, when I found myself separated from some friends, and attempted to cross the course, but the police forced me to return, and I was ignominiously relegated to the rear of the crowd opposite the Grand and Royal stands and the winning post. I, however, managed to push partly through, and found myself close to an old-fashioned green travelling chariot, which was placed in the first row, and was occupied inside by a benevolent-looking elderly lady. The carriage commanded a view of the Royal box and its occupants. I had the assurance to step on to the hub of one of the forewheels, and to hang on to the leather braces of the $\mathrm{C}$ springs. I, however, raised my hat, and apologised to the lady, hoping I might be permitted to stand there. She, in the kindest possible manner, gave me permission to do so. A grentleman was on the box seat, with whom she conversed, and as the horses were taking their preliminary canter, and were nearing the Royal Stand, she said, "Here comes our colt ; the rider in green. My lord thought we ought to run one this year, but he has no chance whatever of winning. The colt is almost untried, and only three years old, but 
we thought, out of compliment to her Majesty and her visitors, we would start him.' On referring to my card, I found it was 'Lord Albemarle's Colt by Defence,' unnamed. I had therefore been talking to the Countess, and could well understand her remarks, as the Earl was Master of the Horse, and it was only natural that he should be expected to run a horse in the presence of such distinguished spectators. Soon after the start it was observed that the colt was running strong and well; and I found that the butler and footman were placed on the roof of the carriage to view the race, and inform her ladyship how the colt was going. I began to fecl as anxious as though I had a large stake on him, as they called out their views of the running on the far side of the course. The horses were invisible to me, so I only knew from the remarks of the servants what was happening. 'Attila is last, my lady; the colt is alongside the leaders; they can't shake him off; now they are nearing the bend, now they are in the straight. He is still with 'em, he's taking the lead, my lady-he's a length ahead,' whilst the shouting was terrific, and the excitement greater than I ever saw at any race, when the 'Colt by Defence' struggled gallantly home, and won. I congratulated the Countess, and thanked her for her courtesy, and then left, as I wanted to see the ovation. The colt was led up to the Royal Stand, when the Queen and Prince, with their illustrious visitors, congratulated the Earl of Albemarle on his success. 
This Cup Day became a great historic event in the racing world, as the Tzar promised, if he were permitted, to provide the Gold Cup at his own cost annually. Consent being given, the prize was called the 'Emperor's Vase,' and for many years the Tzar bore the expense of the trophy for that race until the breaking out of the Crimean War, when his gift was withdrawn, and the prize resumed the old name of the 'Ascot Gold Cup.' Yet, although the 'Vase' ceased to be the prize, his visit is commemorated by the great Handicap at Newmarket, the 'Cresarewitch,' which still perpetuates the memory of his Imperial visit to Ascot. The sequel was remarkable. I am not quite sure if my dates are correct, but, if my memory serves, the next year, which, of course, was the first of the 'Emperor's Vase,' the Queen and Prince being again present, the 'Colt by Defence,' then called the 'Emperor,' was brought out, and, to the surprise of every one, his owner more than anybody else, won the race. The excitement caused by the struggle reached a climax when the Earl handed over the trophy as a present to her Majesty, and performed an equally graceful act, as a memento not only of the Emperor's visit, but as a retum for his handsome gift, when he sent over his colt, the 'Emperor,' to St. Petersburg, as a present to his Imperial Highness, and in acknowledgment of his patronage of the British Turf. The horse was added to the Imperial stud, where he afterwards proved of distinguished service. 
Another of my visits to Royal Ascot was made memorable to me by the dead heat for the Cup by Buckstone and Tim Whiffler. The excitement of the public at this event was, perhaps, greater than when the 'Colt by Defence' won the Emperor's Vase. The race was very severe, and it was generally thought that an arrangement would be made to divide the stakes, as the course then was nearly three miles and a half, but as the principal portion was the historic Gold Cup, that alternative was impossible. I thought it would be more interesting to see the struggle from the bend, and thus form a better opinion of the relative merits after they had done their three miles. The deciding heat was a race from end to end, and it bade fair to repeat the former result-another dead heat. When they passed me there was not a pin to choose between them. Whilst I hurried up the course behind them it was impossible, a hundred yards off, to say which had won. Tim Whiffler, however, was beaten by a length. The latter had been much fancied, as he had won the Chester Cup, and Buclistone had acquitted himself handsomely during the spring. This time I did not ride all the way to Ascot and back, as it was too much both for myself and 'conveyance,' who was left comfortably in the stable. 


\section{CHAPTER VII}

Parliamentary elections-Origin of the representation of the peopleAlfred the Great and the Witanagemot-Ancient franchises-The Potwaller-Borough of Aylesbury-Addition of 'The Hundreds'John Webb, ninety-six years old, the last of the PotwallersCustoms at the nomination-Dinners-Conveyances-Duration of polling period-A candidate's ' little bill ' - The poll-The voters' dinners: daily bill of fare-General Election of 1784 -Curions incident-The great Aylesbury case, Ashby $v$. White-Its effect.

Amongst the events which affect the Imperial interest of the kingdom, none have a greater influence than the election of nembers of the House of Commons. The history of the representation of the people has been often recorded, and various accounts have been given of the practice of Parliamentary elections. Most writers have held, and I think with great reason, that the first notice of a real Parliament, that is to say, of the expression of the wishes of the people, was in the Saxon 'Witanagemot,' which undoubtedly existed, and was consolidated by Alfred the Great; but it was not till some centuries afterwards that the election for the assembly was put on a legal footing. Lord Beaconsfield once said to me in a conversation I had with him, that the earliest recorded parliaments were almost entirely chosen by the universal suffrage of the resident people. I concurred in his lordship's opinion, because it was within my own knowledge that, in many boroughs, the old franchise 
of the 'Potwaller' still existed, in my own town of Aylesbury that franchise being very highly prized. There is still one voter living (A.D. 1897) who retains the privilege-I refer to Mr. John Webb-who is ninety-six years of age. Such voters were, along with many others, disfranchised by the Reform Bill of 1832 , but the then existing 'Potwallers' were allowed to retain the franchise. This ancient privilege was granted exclusively to certain towns, and it was claimed and used by 'every man who boiled his own pot,' that is, who had a hearth of his own. It often happened that two men occupied one house, but if the tenement was divided so as to admit of each tenant occupying separate rooms, and each was independent of the other, they had the privilege of voting separately at the election of a member for Parliament. It has often puzzled many writers to understand how boroughs of present insignificance that were disfranchised by the Reform Bill of ' 32 ever became entitled to send members to Parliament. They must, even at their establishment, have been comparatively small places, when towns of much greater importance were unrepresented. It must not, however, be inferred that because such towns are now unimportant they were not places of some consequence centuries ago. They generally then represented a distinguished family or personage in the State. But I am not writing in defence of decayed boroughs, or a history of the Parliaments of England. Accept my observations rather as a slight introduction to some remarkable chronicles which I have been personally enabled 
to preserve. I have lived in an atmosphere of continual Parliamentary strife in my native county of Bucks, that 'great historic county,' so named by its distinguished member, 'Benjamin Disraeli.'

Bucks has been the seat of many a severe party struggle; and though it contained, before the Reform Bill of '32, two or three real pocket boroughs, yet the other boroughs, and the county itself, were often the scenes of close contests, and of dramatically varied successes. So different were the practices of old Parliamentary elections to those of the present time, that electors nowadays feel a difficulty in realising what the system of choosing a representative was, before the introduction of the ballot. That system carried with it the old nomination day,' and the poll was taken by open voting; while the poll for boroughs could remain open for a week, and that for counties to fourteen days. I well remember the last election before the passing of the 1832 Reform Bill, when the poll for the borough and hundreds of Aylesbury was kept open five days, and that for the county for the same period. They were closed because the unsuccessful candidate resigned when he saw his efforts were hopeless. The nomination day was a most important factor in the contest, and was the scene of tremendous uproar and confusion, as all the inhabitants had a right to be present, and they expressed their opinions in no uncertain manner. Personal encounters often occurred, and the speeches of proposer, seconder, and candidates were frequently made in dumb show. But where a speaker was generally popular, there 
was, I need scarcely say, no trouble in obtaining silence. Colours, or 'favours' as they were called, were freely given away and worn. The bands brayed their loudest, and after the poll was declared, and the member duly elected, the 'chairing' of the member took place. The chair itself was a very elaborate piece of furniture. It was like a modern drawing-room easy chair, was covered with silk in the colours of the candidate, and loaded with bows of satin. The bearers were stout fellows, who were well paid for their services, although they were invariably enthusiastic supporters of the party. There were generally eight of them. They raised the honourable M.P. upon their shoulders, and carried him round the town. The band led the way, followed by a strong body of stavesmen, who, with stout fork's-tails for batons, surrounded 'the chair,' to protect the distinguished occupant against the attacks of the defeated party. It was during this perambulation that the hostility was wont to break out, and I have seen desperate fights, with more than a hundred combatants engaged, and in many instances, although the band loudly proclaimed 'See the conquering hero comes,' the M.P. was ejected from the chair, and pitched headlong into the crowd. Like most public events in England the proceedings culminated in a dinner, which was a scene of excessive conviviality. I am enabled, from documents in my possession, to give an electioneering bill at the contest in I 8 I $S$ for the borough and hundreds of Aylesbury. This will tend to show how expensive these elections were. The candi- 
dates at the said election were Lord Nugent and the Hon. Charles Compton Cavendish, some years afterwards member for the county, and created first Lord Chesham, the old members, and Mr. William Rickford, the banker. Mr. Cavendish (who lost the election) and his friends occupied the principal inn in the town, the 'White Hart.' The committee met in March, and in three months they ran up a bill for $287 \%$. 2s. 2d. There was in addition an 'executive committee,' whose little bill (all for eating and drinking) amounted to Io8/. $4 s .6 d$., whilst the bill for the refreshments of the loyal and independent voters was as follows :-

$$
\text { First Day's Poll, June 24, i } 8 \text { i } 8
$$

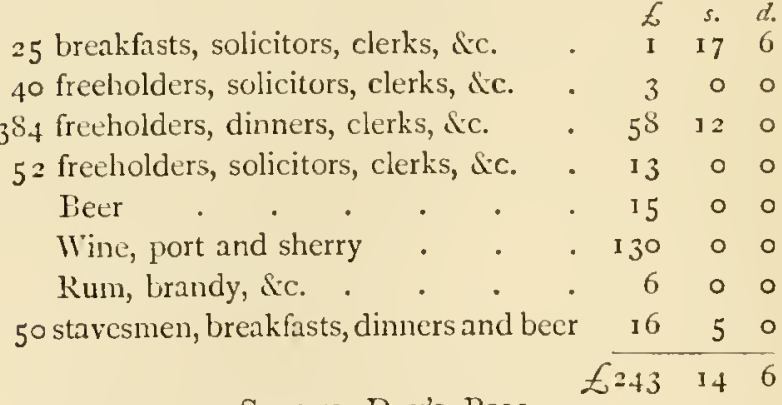

As before, but only 230 voters dined . 17650

Third DAy's POLl

Only I 20 voters dined . • • • $95 \quad 56$

Fourth Day's Poll

Only 25 voters dined $\cdot . \quad \cdot \begin{array}{rrr}30 & 12 & 0 \\ 2545 & 17 & 0\end{array}$

N.B.- I have previously published this account and the next, and re-insert it, it being necessary to elucidate parliamentary elcction customs. 
There were, therefore, 759 voters entertained during the four days, although only 420 voted, so the cost came to about 1 l. $6 s$. per head. On the day of the declaration of the poll, and the chairing of the successful candidates, it was $56 \%$. I 3 s., and for posting and baiting of horses ro5l. Ss. $8 d$.; the total, therefore, was 1, ior $l .9 s .3 d$. The bill was paid at once, and thought to be very moderate. 1 extract also the bill of fare for one day's dinner: 20 dishes of fish, 10 dishes of boiled fowls, 10 dishes of roast fowls, I boiled leg of pork and peaspudding, 2 boiled hams, 2 haunches of mutton, 6 geese, ro pigeon pies, 3 dishes of boiled beef, 3 dishes of roast beef, 2 fillets of veal, I loin of veal, 2 roast legs of pork, 2 forequarters of lamb, 2 dishes of roast turkey, I dish of boiled turkey, 2 dishes of roast pigs, 16 plum puddings, 60 custard puddings, 20 fruit pies, 10 dishes of custards, fruit, blancmange, jellies, \&c. These were in the good old times! It must be mentioned in explanation of many of these heavy items that, at that period, and until the year $1_{32}$, all the polls were taken at one place, and for the county at the county town, which was, in many cases, more than thirty miles from the residence of voters. I have seen the streets of Aylesbury perfectly impassable from the crowding of omnibuses, stage coaches, post-chaises, private carriages, gigs, farm waggons, tradesmen's carts, and other vehicles, which had been requisitioned for the occasion. Yet all the inns and public-houses were crowded, the yards and stables crammed, and 
the market square and principal streets filled with horses and carriages that had set down the voters, who were often compelled to sleep from home after polling. It may be well imagined that it was necessary to prolong the time for taking the poll, when it may be mentioned, for example, that in the county of Bucks voters had to be brought from the little town of Olney in the north, and from Colnebrook in the south, to Aylesbury in the centre, each town being nearly thirty-five miles from the polling place, with the roads frequently in a wretched state.

In one of my books I have told a story which I cannot forbear repeating. It was told me by a very old voter, who vouched for its accuracy. At the general election of $I_{7} S_{4}$ there was a very severe contest for the county of Bucks, the candidates being the Hon. T. Grenville, Sir John Aubrey, Bart., and Lord Verney of Claydon House. The poll lasted fourteen days, and the acrimony with which the contest was carried on may be imagined when I state that, during the poll, a portion of the furniture was brought from Claydon and publicly sold by auction under the order of the Sheriff on the market hill at Aylesbury. His lordship was the popular candidate, and his seat was considered safe on the fourteenth and last day of the poll, as in the morning, about ten o'clock, Verney was about thirty ahead of Aubrey. It is necessary to observe that at that time, whether in borough or county, if the constituency failed to poll one vote within 


\section{COUNTY ELECTION ANECDOTE $\sigma_{3}$}

the hour, the poll closed. The roads were so bad that a large body of voters belonging to the Ashridge and Ivinghoe district had to travel at such a snail's pace it was impossible for them to arrive before eleven or twelve o'clock. The Verney committee, therefore, flattered themselves that their man was quite safe, as there was only another quarter of an hour to elapse before the poll closed. Whilst they were congratulating themselves on their certain success, a violent supporter of their party, and their agent for the Buckingham division of the county, galloped into the town, rushed to the hustings, and recorded his vote for Verney! He hurried at once to the committee room, and exultingly informed his friends that 'he had just given a plumper for my lord.' The chairman shouted out, 'By God, sir, you've lost our election!' And so he had, as his vote kept the poll open for another hour, when the Ashridge tenantry arrived, and Lord Verney was defeated by twenty-four votes! This election impoverished the finances of the Verney family beyond recovery. The following is the state of the poll, which I copy from a printed document in my possession :-

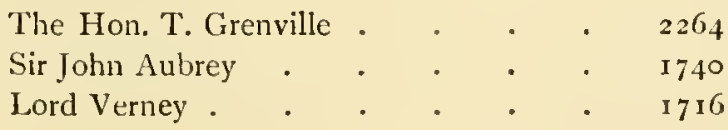

The poll began on Wednesday, April 2I, and closed on May 6, lasting, with the nomination, sixteen days. It was not only eating and drinking 
which ruined many a county family by fighting a Parliamentary contest. Bribery and corruption were fertile snares of ruin to a candidate. In my researches I have been surprised at the numbers of petitions against the return of members, and the enormous legal expenses incurred. I find that on July $3,178_{3}$, Lord Mansfield gave judgment in the Court of Queen's Bench against Lord Rochester in favour of Mr. Petre, respecting damages, in an action for bribery in the election for Cricklade. Mr. Petre recovered damages for $14,000 l$., besides the costs of the suit, which were said to amount to more than 10,000l. A curious case occurred in the little borough of Wendover. The voters in this small place fancied themselves aggrieved by some action of Earl Verney's, and took the opportunity to retaliate. His lordship had every reason to apprehend that he should lose his seat for the county of Bucks, and he therefore offered himself and a Mr. Jolliffe, as candidates for the little borough. The voters were well aware of the sad state of his private affairs, and consequently put up their 'free and independent' suffrages to the highest bidder. A certain individual engaged to find the candidates to contest the seat against his lordship, and his interest, for the round sum of $6,000 l$ ! This was agreed to, and a gentleman was employed to go down accordingly. He was met outside the town, and the voters asked, "What news from the moon?' He answered that he had brought from that satellite $6,000 l$, which was to be 
distributed amongst them by the borough agent. They were then satisfied with the golden news, chose the opposition candidates, and received their cash! That same year at Aylesbury the two gentlemen who had brought the money down to pay those who voted for Messrs. Halifax and Wrightson, the successful candidates, from some misunderstanding refused to pay the cash, and were mobbed by a crowd who would not allow them to proceed to London. Two days afterwards those who voted for these gentlemen received twelve guineas each, but the young voters were refused money by either party, which embittered them vastly. Many of the bills for ribbons, or favours, as they were called, and publicans' accounts were disputed ; some were paid one half, some a quarter, and some nothing, to punish them for making such exorbitant charges.

I have elsewhere given some account of the Bucks election in $\mathrm{I}_{7} \mathrm{~S}_{4}$. I there stated that the Hon. T. Grenville and Sir John Aubrey were elected, Lord Verney being in a minority of only twenty-four after a fourteen days' poll. I find that the latter petitioned against the return; but Sir John Aubrey, and friends who were in the Government, managed to adjourn the petition for more than two years, when Lord Verney was compelled from want of means to abandon the action. The petition was alleged to have cost Sir John Aubrey nearly 50,000l. A great mob attacked the 'George' inn, Mr. Grenville's head-quarters ; they also, on the first day of the poll, 
pulled down the hustings, the poll booths, and destroyed everything they could lay hands on. About fifty of the rioters were captured and lodged in Aylesbury gaol, where many of them caught the spotted fever, and were set at liberty after the election was over. They carried this frightful disease all round the county, and many people died from it. I have every reason to believe that the system of bribery tainted the whole kingdom at Parliamentary elections at that time, and up to the establishment of the ballot the practice existed more or less in many boroughs. The counties were too extended for 'the man in the moon' to utilise his blandishments; and the plan of closing the poll, in one day, was a great blow to corrupt practices. From the poll lasting for so many days, and voters being brought, for many miles, from little country villages, there was every opportunity to exercise the power of gold. In the present day it is questionable whether another form of bribery, now existing, is not nearly, or quite, as pernicious as a money bribe given to an individual. I allude to the gifts of large sums for endowments of societies, the erection of public libraries, baths and wash-houses, the presentation of public parks and recreation grounds, the giving of prizes at agricultural, horticultural, and other associations, and the like, and I question whether they are not as potent as personal bribery in the good old days. There is the still more wholesale and shameless promises to constituents of Acts of Parliament, to carry out the vagaries of political 
faddists, which has of late become so prevalent. The present system of candidates nursing a constituency has one great advantage over the old, it benefits the entire community, and friends and foes alike can participate; whereas in the past only the recipient of 'hard cash' was satisfied. There was a very remarkable case which arose in my native town, whose brief history I may be permitted to give-I refer to the 'Great Aylesbury case of Ashby versus White,' as it is called ; and although it occurred more than a century before my existence, 1 knew so many of the descendants of those who figured therein, that I can somewhat vouch for the authenticity of the events recorded.

This celebrated case, dragged through two Parliaments, causing the dissolution of one, is an important constitutional record. It was simply this. A person named 'Mathew Ashby' in January i 701, at the election for the borough of Aylesbury, tendered his vote for Sir Thomas Lee, Bart., and Simon Mayne, son of the regicide, and the Returning Officers for the borough, of which William White was one, rejected it. A petition was lodged in the House of Commons by Simon Mayne and some other inhabitants, complaining of the Returning Officers' arbitrarily rejecting his vote, and he, Mathew Ashby, stated that the officials in question had been guilty of an illegal act, and proceedings were thereupon taken against them. This case 'dragged its slow length along' interminably, and on January 25, 1703, the House of Commons 
resolved itself into a Committee of the whole House, to take into consideration the Aylesbury case of Ashby $v$. White. After a lengthy debate it was resolved by $215 \% .97$, "That, according to the known laws and usages of Parliament, neither the qualification of any elector, nor the right of any person elected, is cognisable or determinable elsewhere than before the Commons of England in Parliament assembled, except in such cases as are specially provided for by Act of Parliament'; and it was further resolved 'That Mathew Ashby, having, in contempt of the jurisdiction of the House, commenced and prosecuted an action at common law against William White and others for not receiving his vote at an election of burgess to serve in Parliament for the said borough of Aylesbury, is guilty of a breach of the privileges of this House.' Notwithstanding this, in April, Ashby continued his action, and at the late Bucks assizes obtained a verdict of 5l. against the defendants for refusing his vote. On being carried to the King's Bench, and after a long argument, the judges, by 3 to $\mathrm{I}$, decided that the action could not lie, and that the plaintiff Ashby had no cause of action.

In the following October the House of Commons was informed that new actions for five other voters were brought against the Returning Officers, and the House resolved 'That it was a breach of privileges of the House, and that the five men should be committed to the gaol at Newgate, and that Mr. Speaker issue his warrants accordingly, and that 
Robert Mead, attomey-at-law, is guilty of high contempt of the jurisdiction and privileges of the House by prosecuting these actions against the Returning Officers, and that Robert Mead should be committed to the custody of the Sergeant-atArms.' On November $S$ the judges refused a writ of Habeas Corpus, and the prisoners were consequently remanded to Newgate. In February i 704 John Patey and John Oviatt, two of the Aylesbury men committed to Newgate, petitioned for a Writ of Error to bring their case before her Majesty. The House of Commons petitioned the Queen (Anne) not to grant their petition. On February 26, the House of Commons ordered that James Montague, Esq., and five other attorneys be taken into custody for aiding and abetting Patey and others in their action against the Returning Officers at Aylesbury; and on the 27 th the House of Lords gave its protection to all the parties concerned, as counsel, solicitors, \&c., to the Aylesbury men, and prohibited anyone from arresting, imprisoning, or in any way detaining James Montague and others. On the 28 th her Majesty expressed her great regret to the House of Commons, and was much troubled to find that they were against her granting a Writ of Error, as against their privileges, of which her Majesty would always be as tender as her own prerogative, and that the House might depend that she would do nothing to give them just cause of complaint; but that this matter relating to the course of judicial procedure, being 
of the highest importance, her Majesty thinks it necessary to weigh and consider very carefully what may be proper for her to do in a thing of so great concern.

On March 2 the Sergeant-at-Arms reported to the House of Commons that he had taken Montague, but that he had produced a protection from the House of Lords ; that he had nearly taken Letchmore, but that he had tied his sheets together, and had slipped out at a back window two pair high; and he had also taken Harris, but the other three, Page, Denton, and Lee, were not to be found. A conference was then held by the two Houses, and after long arguments the House of Commons resolved 'That the proceedings of the House, in relation to the Aylesbury men, are in maintenance of the ancient and undoubted rights and privileges of the Commons of England.' On April I the Ashby case was brought by a Writ of Error before the House of Lords, and Sir Thomas Trevor, Lord Chief Justice of Common Pleas, delivered judgment, by which he overruled the decision of the Court of King's Bench, and gave judgment for Ashby. In December following; Oviatt, Patey, and others petitioned the House of Lords to remove them from the gaol at Newgate. In February 1705 the House of Lords had passed no less than six resolutions 'condemning the conduct of the House of Commons, as being an obstruction to justice, and contrary to "Magna Charta" '; and the House of Commons passed resolutions 
PRIVILEGES OF THE COMMONS $71^{\circ}$

diametrically opposed to the House of Lords. On March 14 the peers attended the Queen with a long representation of the Aylesbury election case; they affirmed that the proceedings of the Commons were wholly new and unprecedented, and it was the birthright of Englishmen to seek for redress for any injury in her Majesty's Courts of Justice. The Queen, finding it an absolute necessity to put an end to the session, and knowing there could be no further proceedings in the matter, prorogued Parliament the same day, and so rid herself and others of the Aylesbury election business, which had set Queen, Lords, and Commons at variance for the past four years.

On April 5 Parliament was dissolved, and after that nothing more was heard of the great Aylesbury case of 'Ashby versus White.' 1 have thought a condensed account of this often-quoted great constitutional case would interest many persons who felt some desire to follow the development of our Parliamentary history, and have, in fulfilment of my object, diligently searched many public documents, but really am less indebted to them than to my old friend, the late Mr. Robert Gibbs, from whose pen I have gleaned a great part of these details. I have been informed that, after all, the real question was whether the Returning Officers were justified in refusing Mathew Ashby's vote, under the plea that he had received parish relief. However, this celebrated case is another illustration of the great value of the House of Lords 
in standing up for the liberties of the people against the arbitrary and unjustifiable tyranny of the House of Commons. It may not be out of place to mention that in many boroughs there was no regular locality in or at which nominations took place. I well remember seeing the last election for Amersham, in $I_{32}$, when the two candidates, Squire and Colonel Drake, stood on two very large unhewn stones, outside the Market House, in the public street, and were there proposed. At Aylesbury, up to $\mathrm{I} S \mathrm{O} 2$, the candidates were proposed on a large tombstone in the churchyard; after that year, when the hundreds were added to the borough, the nomination took place in the County Hall. At Old Sarum and Grampound, inasnuch as there was but one house in each of these boroughs, the members were nominated and elected on a mound of earth somewhere within the reputed parish boundaries. 


\section{CHAPTER VIII}

An eccentric country gentleman-Egryptologist and astronomerSingular political career-Rural pursuits-His marriages-Establishment of prize gooseberry shows-Practices of exhibitorsNames of noted gooseberries-Jas. Carter, landlord of the 'Bugle" inn-Teetotal festivities-Dr. Lee in excelsis-Elihu BurrittDrunken orgies of the visitors to the Teetotal banquets-The historic career of the Lee family-Their remarkable influenceAdmiral Smythe-Old Wiggs, the parish clerk-'A:des Hartwelliane'-The museum-Hartwell House, the seven years' residence of Louis XVIII.

Amongst the many gentlemen I have known and been pleased to call my friends was John Lee, LL.D., of Hartwell House, near Aylesbury. He was an extraordinary character, and was known far and wide for his benevolence, his eccentricity, and his versatility. His whole career was marked by changes of position in society, whilst his vagaries as a politician, as a Doctors' Commons lawyer, and as a country gentleman, were varied by his studies in Egyptian antiquity, and other similar fields of research. But his greatest achievements were in the study of the heavenly bodies; and, as an astronomer particularly and scientist generally, he was deservedly held in high esteem. His eccentricities culminated in a sudden manifestation of zeal on behalf of teetotalism, and his personal exertions for those enthusiastic faddists, the total abstainers, 
led him into many extravagances, while his trusting, benevolent disposition made him the easy prey of the designing members of the fraternity, who did not hesitate to invade his household for weeks together, whilst the branch societies and offshoots obtained many a cheque under pretence of 'advancing the cause,' but to whom the funds went was only known to the recipient. The learned doctor also became a patron of 'vegetarianism' and 'antivaccination.' Notwithstanding his admiration of, and intimacy with Mr. Robert Ceely, the eminent authority, since Jenner, on vaccination, these 'fads ' found a powerful supporter in him. As an antiChurch-rate man he figured prominently, and after passing for some years as a Tory country gentleman, he suddenly turned his coat, and became a venomous Radical, if it were possible that his truly charitable mind was capable of expressing the violent animosities fostered by this political party. The doctor's person was as eccentric in appearance as his costume. He was slightly above the middle height, with a thin, haggard face, and sparse straggling locks worn rather long. This singular figure was generally clothed in a long blue coat with plain brass buttons, a full white cravat, and a frilled shirt, dark trousers, low shoes, tied with black ribbon, and his head was surmounted with a tall chimneypot hat, often scant of nap. With all his loudly expressed democratic opinions, he was every inch an aristocrat, and proud of his lineage from the Lees of Quarrendon and of Ditchley. His mother 


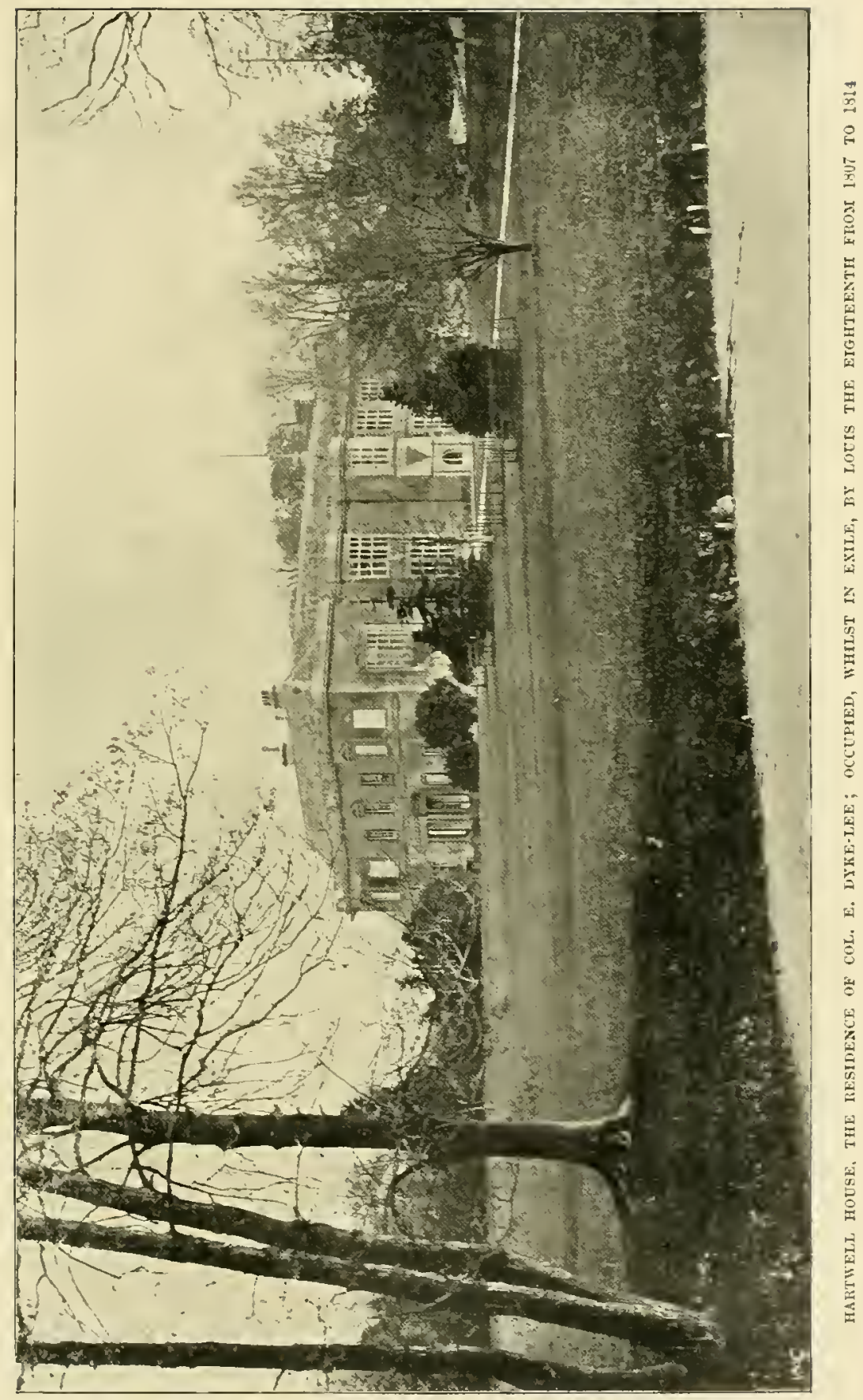



was the sister of the last baronet, Sir George Lee; she had married a Mr. Fiott, so that the learned doctor was 'John Fiott,' LL.D., of Doctors' Commons, London, and on the death of Sir George he succeeded to the family estates in Bucks, Beds, and Herts, and took the ancestral name of 'Lee,' and came to reside at Hartwell House. This stately mansion, a fine specimen of Elizabethan and early Italian architecture, stands in a lovely park, ornamented with grand trees, many noble specimens of which were near the house, adding greatly to the beauty of the park and grounds. In I 807 this place was selected, by the Government of the day, as the residence of Louis XVIII. (Louis le Désiré) and his family, with their Royal household, when driven from France by the Emperor Napoleon, and there the Court remained for seven years. The gardens contained a bowling-green sub tegmine fagi. The beech trees overhanging it were fine specimens, and the umbrageous walks surrounding the house delightful. IVell might the Royal family of France part with their retreat with the deepest regret, as is evinced by the carvings on some of the trees in the park and grounds surrounding the house, such as 'Toujours heureux,' 'Quel plaisir;' \&c. The French Queen died here, and on the return of the King to France, her body was removed, and buried at St. Denis, near Paris, in 1814.

Late in life Dr. Lee married a most estimable middle-aged lady, with whom he lived many years. She died childless; and a few years afterwards he 
married Miss Heath, who was nearly forty years his junior. She survived him, and on her death his property descended to his nephew, Colonel Edward Dyke Lee, the present owner of Hartwell, and the other properties, who resides at the mansion, and is a most excellent, liberal-minded country gentleman. Whilst giving this sketch of Dr. Lee, it occurs to me to describe some characteristics of rural life.

Forty years ago, at Hartwell and thereabouts, were the meetings of the 'Gooseberry Society,' a show that was held at the hostelry near the park, called the 'Bugle,' and a dinner afterwards, at which the doctor presided, accompanied by many London and country friends, with the leading farmers of the parishes of Hartwell and Stone. There were many members of the society resident in Aylesbury who invariably made a practice of attending, and exhibiting the produce of their gardens, myself among the number. This gathering was much augmented on the verge of a Parliamentary election for the borough and hundreds of Aylesbury, these parishes being within the borough. The chief members of the society were cottagers of the two parishes, and the rivalry of the various exhibitors of the 'Big Gooseberry' was intense, whilst the disappointment of the growers, as the day of exhibition approached, was very amusing. One would deplore the fact "that his "Gunner" was busted," another that 'there was a crack in his "Peacock," that his 'Wonderful' had dropped off, or his 'London ' was rotted. These were the names of the various goose- 
berries grown for their monstrosity, as weight, not flavour, carried the day. The cultivation of these fruits was even more amusing than their exhibition. A tree was planted about two years previously, carefully manured and pruned, and when the eventful year arrived, powerful manures were applied, and the fruit thinned out till there were seldom more than three or four berries left on the bush; and it may therefore be well understood that when a 'Gunner,' a 'Peacock,' or a 'London' was busted, how great would be the disappointment. The weighing of the berries singly was watched with the greatest anxiety and the keenest scrutiny, as the prizes were awarded entirely by weight, and the four colours, red, green, yellow, and white, each received the coveted prizes, whilst there was a premier prize of a copper tea-kettle for the grower of the heaviest single berry in the show; these always weighed over $20 \mathrm{dwts}$., and I once remember a red 'London' reaching $27 \mathrm{dwts}$ ! The chairman, Dr. Lee, with some of his 'teetotal' and 'antitobacco' friends, drank the after-dinner toasts in water, which was much lauded, as a very delicious beverage, by the doctor, as the limpid, sparkling drink came from a well-known spring, specially protected with a stone covering, on which was carved in Greek characters "A is best. Yet it is sad to tell that, despite the presence of the 'faddists,' the company in general smoked pipes of tobacco till they were blackened, and instead of washing down the taste of the weed with pure 
water, they preferred and drank Joe Carter's (the host of the 'Bugle') strong ale, besides wines and spirits, till late in the evening; many of them forgetting the route to their own dwellings, and making anything but a teetotal gathering.

As I before stated, when an election for the borough was looming in the not distant future, this Hartwell gooseberry show was a fertile source of supposed bribery and treating, being within the hundreds of Aylesbury, and most of the inhabitants were amongst the worthy, the free, and the independent electors. As it was very uncertain which way Dr. Lee would vote, there were strenuous attempts made by the rival parties to make the meeting a success. In every autumn a monster assembly favourable to 'teetotalism' was held in the park, and for nearly a week delegates from London and other parts of England made a point of attending. The mansion was converted into a sort of liberty hall, open house being the rule, and plenty of feasting took place, for it was remarked that teetotallers were noted 'trenchermen,' and made up by cating what they denied themselves of drinking. Vegetarians throve here mightily, as they drank alcoholic beverages, and the anti-tobacconists could both eat meat and solace themselves with something stronger than water. The meetings of these societies began about noon, and lasted till nine or ten o'clock at night. Bands playing, dancing, 'kiss in the ring,' and rural sports going on well into the dark: Joseph Carter's hostelry, the 'Bugle,' being 
crammed with visitors the whole week, and a general orgie became prevalent. When it is stated that, in addition to all these anti-everything societies, was affiliated the great demonstration of the "Universal Peace Society,' with the champion advocate, Elihu Burritt, the inspired blacksmith, and other noted Americans, with a strong contingent of whisky-drinking Scotchmen, evidently not teetotallers, it may well be conceived that 'high jinks' were the order of the day. In fact, it was well known that such a week of drinking and immorality as was evoked by these gatherings was unknown elsewhere.

Some amusing stories are told of Joe Carter, who was a favourite tenant of the doctor. It was said that when Joseph paid his rent, his landlord kindly asked him if his business at the 'Bugle' was prospering. Joseph replied that he regretted to say that 'it was very bad indeed'; that, what with his friends and visitors attending these meetings, and what with the impressive speeches they heard there, such an effect was produced on his customers generally that they ceased to patronise him as they used to do. This so gratified the doctor that he said, 'Joseph, I am very glad indeed to hear it, and therefore hand you back these three five-pound notes, as some compensation for your loss of trade.' Joseph departed serenely, thanking his landlord for his kindly consideration. But the real facts were these: The jolly host of the 'Bugle' was noted for his famous home-brewed beer, and always filled his cellars, and even his outbuildings, with his nut-brown 
beverage in anticipation of the Temperance festival, and the stock of beer was invariably exhausted after the second day, and the Aylesbury brewery each succeeding day sent in a dray of twelve barrels of beer to supply the deficiency; whilst his wine and spirit merchants provided extra stock, which was always sent in the week before, and consisted of at least twenty gallons of gin, besides rum, brandy, and whisky, was exhausted by the end of the second or third day. This surely was proof enough of the great benefit conferred upon the population by the attendance and speeches of the Goughs, Reynoldses, and other enthusiastic speakers at these meetings.

It happened that after one of the Parliamentary elections, a petition was presented against the return of the newly elected M.P. for bribery and treating. Joseph attended before a committee of the House of Commons to give evidence as to the feasting of the electors at the 'Bugle.' He was a jolly, rollicking fellow, with a rubicund face, well pimpled, and otherwise showing 'how of the black jack to his lips did go.' He was asked, 'If there had been so little drinking at his house, how his face had obtained that singular appearance?' Nothing abashed, Joseph replied 'that he had been sleeping in London the last two nights, and that certain inhabitants of the bed which he slept in had worried him so that he had but little sleep, and they had caused these abrasions and appearances on his face.' This was said in the most deliberate manner, 
and amidst roars of laughter, somewhat at the expense of the Q.C. who was examining him, from both auditors and members of the committee. With all his peculiarities Dr. Lee was a general favourite with all classes, his benevolence and kindness of heart endearing him to every one with whom he was brought in contact. He, with the late Sir Harry Verney, the worthy baronet who died in I 894 at the age of ninety-three, founded the Bucks infirmary, and as a start, and by way of an example to other landowners, he gave $1,000 l$. as a subscription, and, as the work progressed, largely added to his original donation. The 'Lees' of Quarrendon were the ancestors of this Hartwell family. I have elsewhere described the disgraceful state of the parish church at Quarrendon: the fine monuments, which I well remember in the chancel, were memorials of the ancient 'Lees.' Admiral Smyth, in his ' Edes Hartwellianæ,' published in I $564-\mathrm{a}$ copy of which was kindly presented to me by the author and Dr. Lee, 'with their compliments,' on March 22 of that year-describes one of the monuments as 'a costly sarcophagus of Sir Henry Lee, with his effigy in gilt armour, decorated with the insignia of the Garter, erected in $\mathrm{J} 597$, and near him was a fine altar tomb, with recumbent figures of his father and mother upon it.' I have seen these tombs in my youth sadly mutilated, and now (1S94) uttcrly gone. And I have been told that the quiet slumber of death on their features, even then some- 
what defaced, so strongly attracted the admiration of Sir Francis Chantrey, as he told Lord Nugent, when visiting him at Lilies, which was near the chapel, that he had borrowed from them his first idea for the exquisite sleeping sisters in Lichfield Cathedral. The late Dean Bickersteth had been my vicar at Aylesbury for over twenty years, and he showed the group to me with much pleasure when I once visited him at the Deanery. The sisters were the daughters of the Reverend $W$. Robinson, their mother being a beautiful woman, and the daughter of Dean Woodhouse, of Lichfield. Whilst writing of Sir Henry Lee, I find that Ann Vavasour was Maid of Honour to Queen Elizabeth; she was one of the family of Vavasour, who were a great family, and whose ancestor came over with William the Conqueror. He took his name, as being the King's Valvasour, from holding land in fealty, a degree then but little inferior to a Baron. Neither the rank nor the station of this same Ann Vavasour could preserve her from frailty, and on that account her tomb at Quarrendon is said to have been desecrated and defaced by order of the bishop of the diocese-Lincoln. Her shame and degradation were thus moderately commemorated :

Under this stone entombed lies a fair and worthy dame, I)aughter to Henry Vavasour, Ann Vavasour her name; She living with Sir Henry Lee, for love long tyme did dwell, Death could not part them, but here they rest within one cell.

Sir Henry died in 1610 . The above was copied by the Lancaster Herald in 1611 , and the following 
year he made a marginal note to the line, thus: 'This tomb is since erased and pulled down, I612.' Admiral Smyth, to whom I am indebted in the main for the above, says: "Under so open an avowal Sir Henry Lee, the most chivalrous knight of his day, and Sir Walter Scott's type of perfection, may be dubbed a knight sans peur, though, alas! not sans reproche. He being buried at Quarrendon, and his wife and children at Aylesbury, is significant.' In my 'Recollections of Old Country Life' I have described the wife's monument, dated $1_{5} S_{4}$, with that of her children, and am tempted to make a quotation here. Above the canopy there are these lines:

If passing by this tomb thou dost desire To know what in this marble shrine do lie, The some of that which now thou dost require This sclẽder verse to you will soon descrie.

Then follows this inscription, quite Spenserian in its diction: the spelling, with its contraction of the letter ' $n$,' is peculiar :

Entombed here doth lie a worthy dame, Extract and born of noble house and blood. Her sire, Lord Paget, hight of worthy fame, Whose virtues cannot sink in Lethe's flood. Two brethren had she, barõs of this realm, A knight her feere, Sir Henry Lee he hight, To whom she bare three impes, which had to name Jolın, Henry, Mary, slain by fortune's spight ; First two beig̃ young, which caused their parẽts mõe, The third in flower, and prime of all her yeares. All three doe rest within this marble stone, By which the ficklẽess of worldly joyes appears. 
Good friẽd sticke not to strew with crimsõ flowers

This marble stone wherein her cidres rest,

For sure her ghost lives with the heavẽly powers,

And guerdon hath of virtuous life possest.

The words 'he hight' mean 'was his name,' and 'her feere' her companion or husband. The chil. dren are called 'impes.' It had often astonished me why they should have been interred in Aylesbury Church, which was some three miles from the family vault of the Lees of Quarrendon, but the above story explains it.

Dr. Lee's attempts for a seat in Parliament, and his political career, were very amusing. I fancy I can see him now, in or about the year ${ }_{1} S_{45}$, riding through the market square at Aylesbury, in his old phaeton drawn by one horse, and driven by his eccentric, boozy coachman, Ben Monk; the phaeton decorated with a bower of laurels, and the doctor, hat in hand, bowing to the right and left to ladies in the first-floor windows, and followed by a crowd of boys. He was proposed and seconded on the nomination days for the borough, and also for the county of Bucks-the polls were being held simultaneously. For the former he polled about 400 to his opponent's Soo or 900, and for the county about I,O00 as against a little over 2,000. It was said that he changed his colours from the Tories to the Whigs, because Sir R. Peel had refused to revive the baronetcy of the family in himself. He was, as I have said, a great astronomer. In order to pursue his study of the heavenly bodies, he had erected an 
excrescence of an observatory, which rose from his drawing-room window. His extensive stables were turned into an Egyptian Museum, with huge figures of Isis and Osiris, and immense stones with carved hieroglyphics, sarcophagi, with mummy cases depicting Egyptian manners and customs from the times of the early Pharaohs, filling the stalls. I was honoured by being introduced to Mr. J. Bonomi, the celebrated Egyptian traveller, by the doctor, and with these two and Admiral Smyth I spent many a pleasant hour. The last named was a charming companion and a very humorous acquaintance, fond of ayriculture and country folk lore. He delighted in walking over my farm with me and talking with the labourers. Amongst the rural celebrities of Hartwell was old 'Wiggs,' the parish clerk. The admiral was fond of quoting 'his wise saws and modern instances.' Wiggs said he was not surprised at the Queen being fond of farming, as in all her copper money she caused herself to be shown 'as sitting on a cartwheel, with a dung-fork in her hand.' This was Wiggs's description of Britannia on the Union Jack, with the trident in her hand! On the admiral remarking that some horses were idly eating their heads off, he replied, 'Well, sir, I always bless their mouths, and ours too, for if it was not for eating and drinking, what would farming come to?' The admiral, when I had the opportunity of walking with him, was to me the best of company, especially when he got to his favourite subject, Ancient Egypt. Whilst speaking of the manners and 
customs of this wonderful people, he mentioned that the Egyptian ladies used scent and dye upon their persons, and that at Hartwell there was a small vessel, with some of the very scents and dye still in it, more than 2,000 years old, but I cannot describe it so well as he did. In 'Ædles,' p. I $S_{5}$, he writes as follows: 'The female choristers who attended Pharaoh's daughter, on her espousals with Solomon, and who gave title to the forty-fifth Psalm, are shown on a sepulchral stela of Theban limestone. curiously coloured, as smelling a lotus flower, and that the Egyptian damsels were not unmindful of the pomps and vanities of this world was evinced by their fine linen, necklaces, precious stones, gold chains, armlets, bracelets, anklets or bangles, false jewels, enamels, studs, and earrings, of all of which we have the fullest testimony.' Regarding the rich network of bugles, or beads, which is so frequently found enveloping nummies over their linen clothes, the Admiral told me that there was a relic of the same taste, prevailing at the Court of Yussuf, the late Bashaw at 'Tripoli. The Bashaw, after an evening with his songstresses and dancers, would honour his guest (the admiral) as he left the castle, by commanding a network of fragrant jasmines to be thrown over his shoulders as a special mark of grace. He says that a very material article of an Egyptian lady's toilet was the scent-bottle, which contained the preparation of antimony, oxide of manganese, or other substances, to blacken the eyebrows and lids, and this blacking still remains in use all over the Levant. 
These unguents and perfumes were costly, odoriferous, and lasting. I was shown at the Hartwell Museum a perfect little vase, made of so-called alabaster, about four inches high, containing a portion of brown matter, giving out an unctuous smell, a residue of some costly scented ointment. Such was the skill of the Egyptians in the art of perfumery, and so strong was the odour of the perfume, that the scent still remained some thousands of years after. The museum at Hartwell, which had been stocked by the learned doctor, was a strange medley, containing many interesting and valuable remains of remote antiquity, mixed up with wax models of monstrous potatoes, gigantic gooseberries, huge specimens of apples, and other garden produce grown by cottagers on the estate. Amongst the pictures in the mansion were some fine examples of Rembrandt and Vandyke. So little did Dr. Lee respect the amenities of his stately mansion, that when he built that vile excrescence of an observatory on to his state drawing-room window, the entrance to which was through the principal apartments, finding that some noble trees in the park somewhat obstructed his view of the stellar world, he did not hesitate to ruthlessly cut the trunks down halfway, and thus ruined the most beautiful portion of the estate. My intimacy with this interesting country gentleman enabled me to make the acquaintance of many learned gentlemen, in addition to Admiral Smyth and Mr. Glaisher, of Greenwich fame, such as J. Bonomi, the celebrated Egyptian traveller; Pettigrew, the 
distinguished authority on mummies ; Dr. Buckland, the geologist; Gough, the teetotaller; Elihu Burritt, the champion of peace. When this worthy scientist died, he bequeathed the livings of Stone and Hartwell to the Royal Astronomical Society, so that astronomical observations should be carried on in these parishes. He was buried in the parish church, and was regretted by all who knew him. 


\section{CHAPTER IX}

A prize farm-A Yankee fellow traveller-American and English farmers compared-Turning the tables-An English farmer's bill of fare-A farmer's 'pretty turn-out '-Discomfiture of the Professor -Wheat-growing in England and the United States-The Professor's apology.

I IIAVE done my share of travelling during a long and active life, and although I cannot say I have ever told them, I have sometimes listened to what are proverbially known as 'travellers' tales.' To see ourselves as others see us-well, if the sight is not always instructive, it seldom fails to amuse. And especially is it diverting when the observer happens to belong to the sort of traveller Dickens had in his mind's eye when he invented, or adapted, Count Smorltork. I am reminded in this connection of an experience of mine, on a railway journey from Worcester, about twenty years since, in association with Mr. Charles Whitehead, who resides at Barming, near Maidstone, in Kent, and who is one of our highest authorities in fruit-growing and on the insects which affect our crops. I had been appointed with him as a judge of the farming of Worcestershire, to award the prizes for the best cultivated farms in the county. I believe the proprietor of the leading county newspaper offered iool. as a first prize, and the 
Agricultural Society supplemented it with a second prize of $25 \%$, and as hop- and fruit-growing was essentially a part of the cultivation of the county, Mr. Whitehead was appointed with me. In the course of our expedition we visited the farm of Mr. Charles Randall, one of the most noted agriculturists of the day, who resided near Evesham, and is, alas! no more. He was a charming, genial gentleman, and was for many years one of the leading members of the Council of the Royal Agricultural Society of England. On visiting his farm we were most hospitably entertained and detained to dinner, some ladies and gentlemen of the neighbourhood being invited to meet us. We were put up for the night. IVe found the farm the perfection of good culture, the live stock excellent, the most marked being the sheep, for which Mr. Randall had a world-wide reputation, as was evinced by the high prices obtained for his rams at his annual sale. The house stood on an eminence commanding a view of a fine undulating country, and was surrounded with a beautiful well-kept garden blazing with autumnal flowers, everything around being replete with good taste, and showing ample means of keeping the house, grounds, and farm in a high state of cultivation. This farm adjoined the estate and mansion of the Duc de Nemours, Mr. Randall being manager. To him we most unhesitatingly awarded the first prize, the second going to a farm on the banks of the river Severn, at or near Upton-on-Severn. I have been rather particular in describing Mr. 
Randall and his residence from the circumstance I am about to relate.

Whilst returning home, in the compartment of the railway carriage, I encountered a remarkablelooking elderly man with considerable conversational powers, who was accompanied by his wife. There were three other ladies in the carriage, and myself. The gentleman was expatiating on what he had seen since he had been in England. He informed me that he was a Professor of Literature at a university in Baltimore, U.S.A., and was desirous of recording his views and opinions of England on his return to 'Amerca' (sic). Although his stay in this country had been short, he had already obtained much valuable information. I listened with amused interest to his remarks, especially as I found he was explaining the difference between the English farmers and those of the United States, and conparing their superior position with that of the belated Britisher. 'I can assure you,' he said, addressing the lady passengers, 'that our farmers eat meat three times a day.' At this I pricked up my ears, and when he went on to state he found ours as a rule had animal food scarcely once a week, and considered they lived luxuriously if they got meat once a day, I could not resist joining in the conversation. I assured the professor that our farmers could eat meat four times a day if they wished, to which declaration he gave a firm, but courteous denial. We arrived then within a mile of Evesham station, and Mr. Randall's house and grounds became visible 
from the railway. When the learned professor caught sight of it he called his wife's attention to it, as being a most lovely residence, and as beautiful as any he had scen in England. At this I was delighted, and informed him that that was the residence of one of his despised English tenant farmers; that 1 had had the pleasure during the past week of visiting him. And although I could not quite give in full his bill of fare for my dinner, which 1 had much enjoyed, I thought it was as follows: 'Clear soup, salmon and lobster sauce, two entrées, a saddle of four-yearold wedder mutton of his own breeding and feeding, two brace of partridges, sweets made by the ladies of the household, together with Amontillado sherry and Moët's champagne; whilst after dinner we had, as was then the custom, a splendid dessert, with grapes and peaches from his own garden, with the choicest old port and Château Lafitte claret ; that we joined the ladies afterwards with tea and coffee, and that I played a rubber at whist, the ladies enlivening us with music. The entertainment, I ventured to submit, was one that would compare favourably with a Texas or Kentucky farmer of their highest grade. The ladies in the carriage laughed heartily at the professor's discomfiture, especially when I told him that he had evidently mistaken our agricultural labourers for English farmers. The contrast was more fully exemplified when we reached Evesham station, as the lady American expressed her highest admiration of a pretty 'turn-out,' a handsome phaeton, with a pair of ponies driven by a young 
lady, with her mother seated beside her, and a small groom in simple livery attending on them. I recognised my hostess, Mrs. Randall, and her daughter, and apprised our Yankee travellers of the fact that that was the equipage of the before-named tenant farmer. The astonishment of the professor may be conceived. I further informed him that I myself was only a humble tenant farmer. As to our agriculture, perhaps he was not aware that the average crop of wheat per acre in the United States from the superior tenant farmer never exceeded from twelve to sixteen bushels, whilst that of the inferior English agriculturist averaged a crop of from twenty-eight to thirty-two bushels per acre, and that I had grown on five acres the unprecedented amount of eighty-two bushels per acre. The learned professor having exchanged carcls with me, we parted. He, however, wrote to me afterwards, thanking me for correcting the hurried opinions which he had formed of the farmer and corresponding classes from his cursory glance at England. I am aware that Mr. Randall was scarcely a typical specimen of the ordinary tenant farmer, but he was one. At the time when farming was prosperous, many of my neighbouring farmers kept a good table, had a stock of choice wine, and rode a good horse to hounds, and held their own against any others of the community.

A great deal was said some time since about farmers who had been living beyond their income. It was urged that they had no business to ride to 
hounds, or keep a horse for the purpose. Those who use these arguments are ignorant of the fact that it is absolutely necessary that a horse be kept for ordinary business purposes, and it may just as well be a good one, that can be ridden with hounds and driven to market, so as to take the chance of selling him to advantage, as to be only of value to go to plough, or grind corn, and turn the horse-churn. It has been said also that the farmer's daughters have no right to go to boarding school, and play the piano, or to acquire other modern accomplishments. Surely they have as much right to do this as the daughters of the butcher or the baker, who purchase the produce of the farm and supply the household afterwards. When the whole nation is being educated and taught all the 'ologies,' it would be a sad reproach to the farmer who had from two to three thousand pounds employed in his business, if his sons and daughters could not hold their own with others. 


\section{CHAPTER X}

IIcreford cattle-Early history of the breed-Report of the United States Government-Grazing capabilities-Quality of beef-Curious anecdote-Mr. Westcar, of Creslow-Foundation of the Smithfield Club-Introduction of the breed into the Midlands-Duke of Berlford-Lord Berners-Remarkable cattle-Great value of 'Hereford' beef at Christmas-Beauty of the animals-Colour, grandeur, and carriage-General aptitude to fatten.

HAving been for many years an ardent admirer and somewhat successful breeder of Shorthorns, I have arrived at the conclusion that in some districts there are various tribes of cattle which have become, from continuous breeding, and very careful selection of the fittest for the surrounding conditions, as it were, indigenous to certain soils of this country; whilst the developing of special characteristics has naturally fostered a prejudice in favour of the breed, even to the detriment of others. This is well known amongst breeders of Devons, and is still more pronounced in relation to the Herefords. I have never bred Herefords, but have been a grazier and feeder of them for many years. I therefore can state most unhesitatingly that no breed has a greater aptitude to fatten; and when placed in rich pastures on a congenial soil, they lay on flesh, and fatten, more readily than any breed in existence. Some few years since the Government of the 
United States of America was desirous of obtaining all the information available from every country in Europe, of the various breeds of cattle, giving their characteristics for milk and flesh production. They entrusted me with the task of writing a paper on the Hereford tribe. This gave me an opportunity of gaining some very valuable and interesting information in addition to what I already possessed of this race of animals. It is necessary to state that, as a rule, the Hereford is only sure of making a fine carcass of beef in certain localities other than in his own shire. The soil there seems excellently adapted for breeding and rearing these cattle, and only a limited amount of land in that district is considered of sufficient quality for making such beef as the Hereford $o x$ is capable of producing. Some years ago I visited the city of Hereford on the occasion of the Easter fair. This affords a sight that differs from anything of its class in England. Thousands of cattle of this breed are brought here, all of one type and colour, the latter being a deep brownish red, with clear white faces and bellies, a strip of white down the spine, white appearing sometimes on other parts, and the tip of the tail. No appearance of a shorthorn or any other breed was in the city, except, perhaps, a few Devons. There are often eight thousand to nine thousand head brought in for sale at the Easter and Michaelmas fairs.

The history of the modern Hereford breed is somewhat singular. Old Fuller, who wrote two 
hundred years ago, says of Herefordshire, 'that it doth share as deep as any other county in the alphabet of our English commodities, though exceeding in W, for wood, wheat, wool, and water,' and that its wheat was worthy to jostle in pureness with that of Heston, in Middlesex, which furnished manchets for the kings of England, and its Wye salmon was in season all the year round, but he is silent as to cattle. While Drayton sings of fair Suffolk's 'maids and milk,' of the hogs of Hampshire, the calves of Essex, and how

Rich Buckingham doth bear

The name of bread and beef,

but he says nothing about Hereford cattle. I have myself but little doubt that the Herefords were descended from Devonshire strains, which were all of a deep brownish red colour, with snow-white markings. The story of the cause of the white faces is curious. It came from an accident, or a sport of the breeding of a white-faced bull, in the herd of a noted breeder of the last century, Mr. Tully, of Huntington, near Hereford. The story runs that Mr. Tully's herdsman came to his master one Sunday, as he was returning from church, and told him that his favourite cow, which was daily expecting to calve, that morning had produced a bull calf with a white face, such an event never having happened in his herd before. His master at once ordered him to slaughter the calf, as he dared not let it be known that such a stain of 
impure blood should be found in his well-reputed pure herd. The man begged him to go and see it before deciding, as it was the finest calf he had ever seen. Mr. Tully, after seeing the animal, agreed with his man, that it was a wonder, and out of curiosity he would have it reared. This was done, and he grew up to be a remarkably fine animal. The bull was mated with his best cows, and the progeny becane celebrated for their white faces. Many old chroniclers say that the county was distinguished for its breed of white cattle on the banks of the Wye as far back as the tenth century, but the cattle had red or roan ears; and it is recorded that Earl Scudamore, in or about the year I660, had some red cows with white faces from Flanders, and this may be the reason why this noted 'Tully bull,' after a lapse of more than a hundred years, cropped up as a sport, from the deep red cattle of the country. Sometimes the face is mottled with red, whilst many of the best Hereford cattle I have grazed and fatted have been of a light brindled colour, and I have seen Herefords all pure white, but the latter are extremely rare. There is no doubt in my mind that the perpetuation of the white face is through the influence of the white-faced bull, and is a remarkable corroboration of my views expressed some years since in a paper I read at the Central Farmers' Club on 'Breeding; Facts and Principles,' when 1 enounced the dictum 'that the external characteristics are derived from the male 
parent, and the internal organisation follows the female.'

The Hereford breed of cattle had made a great reputation in the beginning of the present century, when Mr. Westcar, of Creslow, near Aylesbury, mainly established the Smithfield Club Cattle Show, where for twenty years in succession he carried off the first prize with his Herefords against all sorts of cattle competing. Mr. Westcar died before my day, but I knew his nephew, Mr. Richard Rowland, who succeeded him in those splendid pastures, and who related to me-whilst standing in the far-famed great ground, on the spot marked by a clump of trees, planted specially as a memorial, where the lifeless body of Mr. IVestcar was found, he having fallen from his horse, and was supposed to have clied from a fit-how the Dulie of Bedford in the beginning of this century had so often expressed his admiration of the splendid cattle exhibited by Mr. Westcar, went down to the great Easter fair at Hereford, leaving all the arrangements for the journey to the great grazier, travelling in his carriage with four post-horses - which is a representative story of the times as to a progress through the country-taking two days for the journey, and stopping one night on the road at the well-known country inn, the 'Staple Hall,' at Witney, accompanied by Lord Berners in another carriage and four, Mr. Westcar going on ahead in the old yellow post-chaise of the period, ordering relays of horses, and preparing accommodation for the party. The noble travellers 
took their ladies and friends with them, so that with the usual retinue of servants they formed a goodly company. The Duke told Mr. Westcar, on their arrival at Hereford on the fair day, to order dinner for a hundred guests at the principal hotel-I think it was the 'Green Dragon'-and he was to invite all the principal breeders and dealers to meet him. He described the annoyance of some of the dealers at these noblemen being brought down to see the grand store bullocks, for it had the effect of raising their price at least $1 \%$. per head. After dinner the Duke and Lord Berners announced their desire to purchase from ten to twenty cows and heifers of the best that could be found; also a couple of high class bulls, to be sent into Bedfordshire, to Woburn, for his Grace, and to establish the breed there; whilst Lord Berners imported his into the Midlands to follow the same, instead of the Longhorns for which he had been long famous. Thus the Herefords became fixed as a great breed in the Midlands. This visit of the Duke of Bedford and Lord Berners, with the continued success of Mr. Westcar at the Smithfield Club Christmas Show, brought the breed prominently into notice, and firmly established their merits.

As an instance of the size and weight attained by these animals at one of the great exhibitions at the beginning of the present century, I find that Mr. Westcar's first prize at the Smithfield Show in the year 1 So 1 measured in length $\delta \mathrm{ft} .11 \mathrm{in.}$, in heright $6 \mathrm{ft} .7 \mathrm{in}$., in girth, behind the shoulder, 
ro ft. 4 in., and he was sold for roo guineas, his dead weight being 247 stones of 8 lbs.! Enormous as the dimensions of this ox were, they were far exceeded by his neighbour, Mr. Grace, of Putlowes, about five miles from Creslow, and about three miles from Aylesbury, which was $7 \mathrm{ft}$. high, $12 \mathrm{ft}$. 4 in. in girth, and weighed 2 So st. when dead! Mr. Potter, a well-known salesman of the time, sold at the Metropolitan Christmas market in $1 S_{12}$ for Mr. Westcar fifty Herefords at an average of 50 guineas each, thus realising 2,500 guineas. Mr. Rowland showed me, when on a visit to him, a book of Mr. Westcar's, recounting that from 1799 to 1811 he sold at various times twenty oxen for 2,123l, or an average of 106l. 6s. each! And a few years since, about the year 1878, when I was visiting Mr. Ledbroke, of Putlowes, successor to Mr. Grace, a fortnight before Christmas, I saw fifty Herefords, then tied up, for which he had obtained 2,500/., or 5ol. each! The class of animals I am now describing is no more. They were five yuars old, worked beast, and even older, they had been harnessed to the yoke, and had therefore attained a great size. Working in the plough is now comparatively rare; early maturity is the present aim of all the best farmers in England, and Hereford oxen are now well fit for the butcher at from two to three years old.

In relation to this subject a slight account of Creslow may not be deemed uninteresting. This is a parish in itself, but is designated 'extra parochial,' 
there being but one habitation in it, viz. the manor house, which is all that remains of a very ancient monastery, as also forming part of the farm buildings. I have seen, in some portions, the old zigzag mouldings of early Norman architecture, but it has for centuries, as a religious house, ceased to exist ; the foundations are still visible, but only a small portion of its former beauty is in sight. The predominant feature of the estate is the famous 'Great Ground,' containing over 350 acres. This is all in one enclosure, and is considered the largest feeding ground in the kingdom. As a proof of the remarkable fertility of this pasture, I have myself seen upwards of 250 head of full-sized cattle, with 500 ewes and lambs, and 20 mares and foals, grazing together, and all rapidly fattening for market. The estate belongs to Lord de Clifford, the whole parish consisting of about 800 acres, not more than 60 or So acres being arable. It is by some believed to have been the birthplace of 'Fair Rosamond,' which adds greatly to its interest. Nothing can exceed the rich pastoral beauty of this district. From the upper ground, at the foot of which is the justly celebrated Fox covert in Mr. Selby Lowndes' country, formerly hunted by the Duke of Grafton and Lord Southampton, the eye wanders over the far-famed Vale of Aylesbury, the old town, the Egilsbireg of the Saxons, standing on some rising ground in the centre, whilst near at hand is Whitchurch, and the rich pastures of Hardwick, and adjoining these places is Quarrendon, the birtliplace 
of St. Osyth, with its small chapel of the fourteenth century, now in ruins, rivalling Creslow in the richness of its pasture. Next to this is Fleet Marston, with its little parish church standing in the middle of a rich feeding enclosure called 'Chapel Ground,' in which parish is Putlowes, the rival of Creslow in fertility; then following onwards there are about twelve miles of matchless grass land along the Eythrope valley, watered by the River Thame, falling into the Isis at Dorchester, in Oxfordshire, and then forming the mighty Tamesis, Thame-Isis, or Thames. After this digression, I must conclude my notice of Hereford cattle, remarking that the cows of this tribe are not such deep milkers as that of the Ayrshires or the Shorthorns, nor is the milk as creamy as the Jerseys or Guernseys, yet their milk is rich and good, and the cows are excellent mothers. I may sum up my notice of this grand tribe of cattle by saying I believe the Hereford breed, as a flesh. forming animal, has no superior. The meat itself is as good as the best Scotch or Devon, and it is well known that the breed, when exported, succeeds in any climate; therefore England may well be proud of her white-faced Herefords. In no part of the world is to be found a more picturesque sight than a rich deep green pasture, well tenanted with this beautiful race of horned animals. Their sweet calm countenances of curled silky hair, their rich brown-red coats, set off by the pure white of the face, back, and bosom, with the meek glance of their eyes, the pink skin of their lips and nostrils, 
104 RECORDS OF OLD TIMES

their wide spreading horns, and the general contentment of their habits, make them the 'admired of all admirers.'

On searching some old documents I learn that on December 10, I799, Mr. Westcar sent an ox to the Christmas Show in London by a boat on the Wendover Canal. It was only two days on the journey, and lost no flesh by the transit. This was the first record of sending cattle by canal. This Hereford ox won first prize, weighed 24 I stone, and was sold for $100 /$ ! 


\section{CHAPTER XI}

Old unns-Politics-Inn signs and therr origin-Posting and coaching - The 'White Hart' at Aylesbury-The extensive gardens, the offices, and appointments of the 'White Hart' - County importance of the grand old inn-Names of the rooms-The 'Old Bell' in Holborn-Customs of the dinner-table-To Drury Lane Theatre after dinner-Other old inns-Rise of the modern hotel-Bacon's Hotel, Great Queen Street-Railway hotels-Present managers and past proprietors contrasted.

Iт has often struck me that an interesting chapter might be written upon ancient or well-known Inns. I use this old English name in contradiction to that modern Frenchified word Hotel, which was scarcely known in England prior to the battle of IVaterloo. People living in the present day fail to thoroughly comprehend the immense influence possessed in the country by these well-known establishments at that period. In politics, the inns, and their keepers, were a powerful institution, and I can never understand why these generally prosperous, well-to-do traders should in the present day be looked down on, or in any wise despised in their vocation, by people who could but little know mine host or the members of his family. In my youth, the power of the coach proprietors and post-masters in country districts were paramount in their localities. The immense capital employed by them can scarcely be 
credited in the present day. Many of the former owned and employed from six hundred to one thousand horses, to enable them to horse the coaches on the various lines of road; whilst the post-masters often kept from twenty-five to thirty pairs of posthorses. The innkeepers had by far the largest amount of capital invested in the principal towns, far greater, relatively speaking, than was employed in other business. And in the county towns they were generally men of superior education and manners, from their constant association with the leading nobility, clergy, and magistracy, both socially and politically. The chief towns had mostly two leading hostelries, engaged at election times by the rival parties; whilst the leaders, and their followers of Whig and Tory, made the inns their special rendezvous. If I give some account of the wellknown ancient inn of the Midlands, the 'White Hart,' at Aylesbury, it may interest many readers to obtain some idea as to what it was like in the first quarter of the nineteenth century. It is generally believed that this was an inn during the Wars of the Roses, at least five hundred years ago, and belonged to the White Rose party, whilst the Roebuck was attached to the Red Rose. Where ancient inns existed in towns of some pretensions, they were generally the White and the Red Lion, respectively at tached to the two factions. The 'White Hart' stood in the market square of Aylesbury, and adjoined the County Hall, with the Assize Courts. In $1 \delta_{12}$, the front consisted of three tall gables, the first floor overlapping the 


\section{DESCRIPTION OF AN OLD INN IOZ}

ground floor, and the second overhanging the first. Fine carved timbers skirted the gables. In the centre was a large gateway, the floor above supported by great fluted posts, with heavy hanging oak gates, which could be closed when required. This confronted a spacious yard, one half of which was bounded by an open covered gallery, into which the bedroon doors opened. This gallery was supported on strong oak pillars; a broad covered staircase rose from near the entrance into the gallery, and formed the main approach to the principal sitting and bedrooms. There were large rooms on either side of the entrance, and adjoining was the business portion of the inn. A spacious kitchen filled one end of the yard, extensive cellarage occupying the underground of the front. At the back of the buildings were large gardens, with a beautiful ornamental 'bowling green ' of full size, but seldom seen nowadays; on each side were gigantic elms, at least three centuries old, with dense shrubberies, and flowering shrubs, laburnums, lilacs, mountain ash, acacias, and red chestnuts. Along the bottom of the green was a row of ancient walnut trees, arbours with shady nooks, and seats pervaded a shrubbery charming to behold. Below this pleasaunce was an orchard with fine apple and pear trees, amongst the former being codlins, golden and ribston pippins, Blenheim orange, russets, and early juneatings, the latter had Gansell's bergamot, several of the beurrés, and a large tree of the real old bergamot pear. But the chief pride of the place were three very 
ancient mulberries, at least three centuries old. The orchard contained the cow-house, piggeries, and hospital for horses when lame or ill. This orchard was bounded by a mill stream, and in the midst was a large shallow pond, called a 'stew,' for fresh-water fish, in which was kept an eel trunk, consisting of a strong iron-bound box about four feet long and two feet wide and deep, perforated with holes, and a lid fastened with lock and key, the latter kept by the man cook, who was the head of the servants. In this trunk or box were kept live eels, the trunk having a strong iron chain attached to it, which was fastened to the base of a large tree adjoining; this enabled the trunk to be hauled up a sloping bank, when the wriggling occupants could be taken out, affording a delicious dish when company required fish. Two or three big perch, with the same number of tench, were also kept there. This was very necessary, as there were rarely any fishmongers' shops then in the town, and sea fish only came down from London when plentiful, and was brought by the stage coaches. The brook side was edged by large silvery-leaved Abèle trees of more than a century old. A rookery was established in the elms, and plenty of starlings had done the same in the hollow holes in the trunks of the Abèles. The stables were stalled. Boxes being almost unknown, timber and brick built, some of them had what were called bails, large pieces of timber fastened by a short chain to the manger, hanging by chains to a beam in the ceiling above. The lofts for hay, straw, and corn 
being over the stables, generally a considerable quantity of corn and fodder was kept for some weeks' consumption. 'There was accommodation for about fifty horses, with harness rooms, and 'ostry' as it was called, being the office and store room for the ostler, with stove and waiting room for the postboys, and capacious chaise and coach houses. The whole of this establishment covered from five to six acres. It may well be imagined, therefore, that a considerable amount of capital was employed by the proprietor of a large respectable old-fashioned country inn. The servants comprised, besides the innkeeper and his industrious wife, a housekeeper and barmaid, man cook, waiter and under waiter, kitchen maid, scullery maid, chamber maid, laundress, housemaid, nurse, boots, ostler, tap-boy, first turn postboy, and generally an extra woman, making fourteen persons besides the family to feed and lodge daily. The expenses must necessarily have been very heavy. Many old inns had curious legends and ristories attached to them, and one of remarkable historic interest belonged to the 'White Hart.' I have the authority of Clarendon for its authenticity, which I have already described. The large diningroom and apartments, with sleeping rooms over, formed a very picturesque garden front, and bore the date on the gable, in iron figures, of 1663 .

As an instance of the importance attached to this old hostelry, it will be necessary to give the names of some of the rooms on the ground floor. On one side of the gateway was the 'Change,' 
which I have heard old people say was the room where the principal business transactions of the town were discussed and carried out, and in my day was 'the commercial room.' On the other side was the 'Crown,' where the customs, excise, and other duties were periodically collected. Another room was the 'Mitre,' where the Bishop of the Diocese had for three hundred years collected his ecclesiastical fees and clues by his chancellor, as also the archdeacon did the same by his apparitor. 'There was also the 'Fountain,' a name often appertaining to old inns; this sometimes gave the name to the inn itself. There has always been much speculation and doubt as to the origin of this term, but we know it often existed with inns of this importance. It might have meant and represented the modern bar, the place, or fount where the beer, wine, and liquors were kept and served to customers. It has often puzzled me to know what steps were taken at that time to protect the open galleries, forming the approach to the bedrooms, when heavy rain and snow fell. There was a sort of dado fixed about three feet high on the outside, and probably heavy curtains could be let down, especially in cold wintry weather. Often these inns had their own brewery, as almost everyone at that time brewed his own beer, even in private houses, where the establishment was large enough. The cellarage was ample and convenient, generally well stocked with generous old port and rich brown sherry. French wines were only kept in small quantities, 
as they were very expensive, and but seldom asked for.

About the year IS14, business having much increased, and the old inn being devoid of modern sanitary requirements, and on an examination of its structure, it was proved to be very insecure. The whole of the front was pulled down and rebuilt in the inartistic style then prevalent, but leaving all the back part, with the Rochester room, kitchens, and appurtenances, intact ; the old gallery was enclosed, windows being inserted. The great staircase was destroyed, and a new one of carved oak was built, starting from the entrance hall, which occupied the site of the old gateway, a new entrance into the yard being provided on the eastern side of the house. The fine old pile of $166_{3}$, including the Rochester dining-room, fortunately was left intact. Such was the state of this noted hostelry in $1 S_{14}$.

This all happened some time before I was born, but years afterwards I heard people talking of the old house, and everyone regretted that no record, in the shape of a drawing or sketch of the picturesque old front, remained. Yet there is one story about it which my father had been told, and I had heard related by very old people, that whilst the Assizes were being held-the Courts being next door-they had seen serjeants-at-law and other great luminaries of the bar come down between the trials, or at the temporary adjournment of the Courts, going into the 'Change' and playing single-stick across the table, and drinking their social cup. And that when 


\section{12 RECORDS OF OLD TIMES}

any public event or holiday took place, a stage was erected in the yard, and the ladies with their friends occupied the open gallery and witnessed the sparring matches and cock fighting which took place there. The new inn was built from the bath stone and timbers from Lord Chesterfield's house at Eythrope, which was then being pulled down, and the portico was from the stables there.

I have feebly described a well-known inn of some centuries' repute, and before the railways there were plenty as good, but few possessing the great advantage of extensive gardens and grounds, although there was one I remember, and which still exists - the 'Swan,' at Bedford, on the banks of the Ouse, although the gardens and grounds have been much curtailed during the past few years.

I have alluded to the 'Old Bell,' Holborn, now closing and pulling down, and I was tempted to enter through the gateway a few months since, and found the coffee room of my boyhood occupying the same spot, yet strangely altered internally. I am not aware if there is any coffee room in London left as it existed in my early days. This room was fitted with mahogany divisions, partitioning off the place into 'boxes,' as they were called, some holding two persons, some four, and one held six or eight, who could find room to dine; they had stuffed horsehair seats fitted to the walls and partitions, and a fixed dining-table in the centre, whilst the waiter was obliged to hand the viands and the wines over the shoulders of the occupants; these were always ample and of the best quality. The proprietor, 
A DINNER OF THE PERIOD 113

Mr. Bunyer, was proud to bring in the bottle of old port himself, and was often asked to sit down and partake of it. A typical dinner I can well remember, when my father and three of his fellow townsmen, who always made a point of coming to London together when business called them. These little parties were for social companionship, and arrangements were made some time beforehand, that they might book their places by the stage coach, and have no disappointment. Leaving home by the four-horse coach at 7 A.M., arriving in town about I.3O P.M., in time for luncheon of a clever mutton chop, then making a hurried visit to the wholesale business houses, where they were in the habit of doing business, during the afternoon; making their appointments for next day; returning to the 'Old Bell' about five o'clock, having ordered dinner to be ready at six o'clock sharp. Mock turtle, cod and oysters, or salmon and lobster sauce, a good rump steak and pancakes to follow, with Cheshire or Stilton cheese to finish. Old brown sherry, with soup and fish; fine old port with the cheese, and another bottle afterwards. 'Then to the 'Play' at $7 \cdot 30$, Drury Lane preferred. The real old hackney coach with pair of horses. These coaches, with the driver and coat of four or six capes, the horses and appurtenances, would scarcely be credited in the present day. These had originally been the big family carriages of old-fashioned noblemen or country gentlemen. The 'hanger on' of the coach stand usually accompanied the vehicle to earn sixpence 


\section{II4 RECORDS OF OLD TIMES}

by opening and shutting the door. By the way, there is a very good old story of these worthies that I fancy is worth repeating. He was called the 'waterman,' whose duty it was to give the horses water. The story goes that the following colloquy took place: 'I say, Bill, vy do they call us vatermen ?' 'Vell, I don't know, Jem, I suppose 'tis 'cos ve opens the hackney-coach doors.' I think the fare from the 'Old Bell' to Drury Lane was two shillings. I well remember on one occasion seeing Macready in 'Macbeth,' and either Miss Helen Faucit or Miss Huddart in the character of Lady Macbeth-and finely that character was played. I was much impressed with the fight and Macduff's triumph. I shall never forget Macready's wonderful expression of countenance when Macduff told him 'he was not of woman born.' His hand, clutching his sword, fell powerless by his side, his eyes glared, his face seemed to turn pallıd, his mouth half opened his tongue lolled from his mouth, and he looked a complete idiot. But when Macduff accused him of cowardice, in an instant the whole man changed, the idiotcy left him, and the torrent of his voice, ' Lay on, Macduff,' fairly electrified me, as also did the fine performance of Lady Macbeth. I heard a good story of old Mr. Robert Vernon, the generous connoisseur who left his priceless collection of pictures to the nation, the collection that is known as the Vernon Gallery. He was a great patron of the drama, and often received parties of clistinguished actors and actresses on a visit to his beautiful 


\section{ANECDOTE OF EDMUND KEAN II}

country seat at Ardington, near Wantage, in Berkshire. Once, when Edmund Kean was visiting there, he told his host that in his early career he was acting the part of Richard the Third in a small country place, and was lodging at the principal inn, and had given the landlord a ticket to witness the performance. When, on his return after the play, he entered the room where many of the leading inhabitants who had witnessed the performance had assembled and were discussing the merits of the actor. The landlord was smoking his pipe, and as he was the oracle of the place, his opinions were anxiously awaited. So when Edmund Kean asked him what he thought of his performance, the landlord, after pausing some time to collect his thoughts, knocked the ashes out of his pipe, refilled and lighted it, and while the company hung upon his lips, he said : 'Damned good fight.' Alas! these chimney corners in these cosy old country inns are no more, or at least are few and far between. Perhaps in the near or distant future they will revive in some form with the present craze for cycling. Whilst dwelling upon the London Inns of my youth, it will be of little use my mentioning them, as only a very few are left. In my day there were the 'Green Dragon,' Bishopsgate; the 'Castle and Falcon,' Aldersgate —still first-class and flourishing; 'Spread Eagle,' Gracechurch Street; 'King's Arms,' Snow Hill ; 'Swan with Two Necks,' Lad Lane; 'Belle Sauvage,' Ludgate Hill; 'Bull and Mouth,' afterwards the 'Queen’s,' St. Martin's le Grand; 'White Horse,' 


\section{I16 RECORDS OF OLD TIMES}

Fetter Lane; the 'Old Bell' and the 'Bull' in Holborn, still going; Gloucester Coffee House, Oxford Street; 'Golden Cross,' Charing Cross, with Hatchett's, Piccadilly, whilst the 'Angel' at Islington, and 'Elephant and Castle,' in the Borough, still maintain their ancient importance by their omnibus connection, in lieu of the four-horse coaches of the thirties and early forties. When the great iron roads and 'puffing Billies' drove Tony Weller and his confrères off the road, the omnibus made a very poor compensation for the loss of the mail coaches.

There is something particularly fascinating to me in watching the development of many trades and industries, and with them the decay of others. Nothing has been more marked or wonderful than the extraordinary progress made in places for the reception of travellers in London. Probably one cause for this characteristic was the immobility of the system of management of the old inns, which seemed to care little for the accommodation of pleasure-seekers visiting the metropolis. It was rarely that the female population from the country visited the great town-a visit from them was seldom more than once in three or four years, if they resided more than twenty or thirty miles from London-so it was almost exclusively men who travelled thither, and then upon business intent. Their journeys were made by four-horse coach, and, as these conveyances ran direct to the inns already mentioned, the latter were chiefly supported by the inhabitants of those districts from 
which the coaches started, and the country through which they passed. The first house which, as far as I remember, laid itself out for the reception and special comfort of ladies and their families was Bacon's Hotel in Great Queen Street. It was next door to the Freemasons' Tavern, of which Mr. Thomas Bacon was then the proprietor. He was a very gentlemanlike man of excellent address and manners, and his wife was a charming lady, well fitted to attract ladies and their families to their comfortable and homely establishment. This hotel was then followed by the 'Golden Cross,' Charing Cross, when suddenly, as if by magic, the railway companies found the paramount necessity of accommodating their numerous travellers, and the London and North-WVestern built the Euston and Victoria hotels. The Midland, Great Northern, the Great IVestern, London Bridge, Victoria, and others followed suit, thus demonstrating that the same necessity existed for passengers by these railways as it did for the coaches, and the routes through which their lines passed. About the same time Morley's, in Trafalgar Square, the 'Langham,' in Portland Place, and others rapidly followed, so that London, which had long borne the reproach of deficient hotel accommodation, developed a series of inns superior to every city on the Continent. The 'Inns of Court,' the 'Royal,' the 'First Avenue,' the 'Grand,' the 'Victoria,' the 'Métropole,' the 'Alexandra,' 'Bailey's,' whilst lately the 'Savoy,' the 'Cecil,' the 'Hans I'lace,' 
with many others, can now be found vying with each other in splendid furniture, excellent cuisine, the best of attendance, and not by any means extravagant in their charges, considering the superior accommodation they afford. There is, however, one serious drawback in these modern caravanserais-the guests know nothing of the managers, nor do the managers know anything of their guests. The latter are numbered, and, except in the book at the entrance, the name is unknown. No welcome attends you on arrival, no expression of regret at your departure awaits you. No delightful wife of the innkeeper has been seen to cheer and look after the comfort of the ladies; nothing, in fact, to associate the traveller with his Inn, or any pleasing recollection of the agreeable evening, with town or country gossip, over the cigar, in the comfortable bar parlour with 'mine host' at his inn. Whilst speaking of Inns, or to give them their more modern appellation, Hotels, I must not omit a reference to the still more extraordinary development of houses for dining, luncheon, and every description of refreshment. I think in this that London is facile princeps. Only a very few years since the 'gin shop,' as it was called, was almost the only place where even a glass of ale could be obtained, and now every street of the slightest importance has its restaurant. Here again we have another innovation of a French name instead of the 'Eating House,' as it used to be called; we have 'Verrey's,' the 'Holborn,' the 
'Criterion,' the 'Aerated Bread Co.,' with various first-class confectioners, and latterly Messrs. Lyons. All these have become established, and have supplied an increasing want, especially by ladies and children. But amongst all the wonderful places for refreshing the inner man, amongst the humbler classes, are those places called 'Lockhart's Cocoa Rooms'; it is really remarkable how excellent at the price are the refreshments supplied by them. Some short time since I went to one of these houses, had two excellent hot sausages, a large roll, with big cup of good tea, and my bill was 5 d.! Another remarkable feature has also been evolved as to refreshment-viz. the consumption of milk. In nearly every street are attractive, comfortable rooms to be found, where a glass of milk can be had with a biscuit or bun for $2 d$. or $3 d$, tea and coffee also if desired. Yet, with all this, the great Bodegas, drinking bars, wine vaults, and other kindred resorts flourish even more prosperously than before. We may well be proud now of our great city in the shape of new eating and drinking establishments, which, I believe, have been great factors in raising our people from the gross practices of our forefathers, and, let us hope, without the effect of destroying that bonhomic and good fellowship which has always characterised Englishmen. 


\section{20 RECORDS OF OLD TIMES}

\section{CHAPTER XII}

News of the Battle of Watcrloo-Difficulty and delay in getting news at the beginning of the century-The old Winslow coach-" The Dairy Marid' - Report of the great battle brought to my fatherDoubts of its authenticity-Ringing the church bells-lndignation of the vicar-Ultimate triumph of my father-Then and now contrasted-' Our own correspondent.'

THERE are many events worthy of remembrance in my long life which, now in the year 1897 , seem almost incredible. I have heard my father describe the announcement of the Battle of Waterloo with its effects on him, and the recollection of it is so vivid, I seem somehow to have been with him myself. He saicl that on June 20 , in that memorable year, I I $_{5}$, he was haymaking in the meadow at the back of his premises about mid-day, when he heard his name shouted out, and, leaning on his hayfork, he observed the driver of the pair-horse coach called the 'Dairy Maid,' which ran from London, through Aylesbury, to Winslow and Buckingham, which came down one day and returned the next. The coachman was an old friend of my family, of the name of Hodgkins, and he it was who addressed my father, who was then twenty-three years of age, as 'Master John, I bring you great news, and no one in Aylesbury shall know it before you. Bony- 
parte and all his French army are destroyed! The Duke of Wellington, God bless him! has fought and beat him at a place called Waterloo.' My father told me he was so overcome with joy, for he had lived all his life in war, that he involuntarily fell down on his knees in the hayfield and thanked God for what he at once saw was the blessing of peace. The coachman had hurried back, when he found the horses had been changed, and fixing blue ribbons on their heads and a big bow on his whip, drove triumphantly through the town, telling everyone the startling news, which had been spread that morning in London, that the battle had been fought on the I Sth, and that the news had reached London thirty hours afterwards, and that the whole city was rejoicing. Like many other towns of the period, there was a strong contingent of Bonapartists, young men of 'advanced views,' like the Little Englanders of the present day, who were fond of asserting that although Wellington had beaten all Napoleon's generals in the Peninsula, when he came across the great Bonaparte he would not only find his match, but would certainly be defeated. My father, with his staunch Toryism, had always maintained the contrary, hurried up street to the parish clerk, one John Bunce, who, I well remember, was the head of the ringers, told him to call the ringers together and give out as hearty a peal at the church as they possibly could, to celebrate the glorious victory. The peal of eight bells was a very fine one, and soon poured forth a volume of sound powerful 


\section{I22 RECORDS OF OLD TIMES}

enough to shake the steeple. The townsmen hurried out, asking what it all meant, and the streets were soon filled with rejoicing people. The vicarage was close to the church, and the vicar, the Rev. John Morley, was a pronounced Whig and a firm believer in Napoleon, came out and demanded to know what the ringing was about; and on being told, at once ordered them to desist, as he utterly disbelieved the story. But the ringers, who had already been well plied with strong ale, refused to comply, as Mr. Fowler had ordered them; and as he was very popular in the town, they said they were determined to continue, as they felt sure the news was true. The vicar came down to my father's house and heard the story from him, and very reluctantly became a convert to the news, and rejoiced heartily over a glass of hot rum and water and long churchwarden pipe, for which he had a particular fondness, and with which he had often solaced himself with the celebrated Dr. Parr, who was an old college friend of his, and with whom my father had often passed a delightful hour. The vicar could not help rejoicing, being an Englishman first and a Whig afterwards. Later in the evening the stage coaches, especially the mail, corroborated the welcome news, arid general rejoicings took place. I have entered into these details as a record of the times in which the great event took place, and as a contrast to the present day, when stirring events occurring in India, China, Australia, South Africa, North and South America, with all parts of the civilised world. Had 
the great battle been fought now I could imagine the hadings from 'Our Own Correspondent' in the daily papers. 8 A.M..- 'The French are advancing to the attack.' Tavelice o'clock.-'Gallant defence of La Hayue Sainte.' 'Failure of ammunition ; the Hanoverians retire.' 'Repulse of repeated attacks of the French at Hougoumont.' 2.30 F.M.—- Death of General Picton.' 'Polish Lancers attack the Scots Greys.' 3 P.M.-' Repulse and overthrow of the Cuirassiers of the Guard.' Four o'clock.- 'The Duke preparing for a general advance'; ' arrival of the Prussians.' Five o'clock.--'Overthrow of the French Army.' 'Flight of Napoleon,' \&c. \&c. Whereas I have heard from high authority that the head of the great house of Rothschild was awaiting at Brussels, eight miles from Waterloo, with all his plans prepared for his journey to London ; that about five o'slock of the I 8 th, news was brought of the advance of the British in the final charge; that he then started with four post-horses, with relays ready at every stage, to Calais, where a packet was in readiness to convey him to Dover; on the road to London relays of four post-horses hurried him on, arriving about mid-day of the 19th, which enabled him to manage secretly to buy up inmensely of consols and other Government securities, which were at a great discount, before any information reached the Government, by which an enormous fortune was realised in less than forty-eight hours after the battle. 


\section{CHAPTER XIII}

A famous hunting mare-The purchase : her infirmity, her great beauty, and her matchless performances-Her docility and extraordinary pace-Jem Mason-Harborough Brown-The Creslow brook-The beauty of the Vale of Aylesbury as a hunting country-Famous run after a bag fox with Lord Lonsdale's hounds-Captain Barlow -Lord Coventry-The great water jump over the Broughton line of country with the 'Varsity men-Accident to the mare-Partial recovery-Put to the stud-Sudden death-Death of her foal by Hungerford at four years old, and an end of the great huntress.

IT has often been remarked by sporting men that it is seldom 'a man has more than one perfect hunter in his lifetime,' and others have said 'that all men, however badly they have been mounted in the general way, have had one good animal during their riding career.' I may safely say that no man had a better mare than the one whose singular career I am about to describe. Some two or three years after leaving school, my dear and considerate father said to me, 'John, all young men must have some recreation, and I shall be pleased to help you in any reasonable manner which my means and my very large family (there were ten of us) will permit me. Now, I will find a horse for you, or you shall have a dog and gun, but I won't allow you to have both. Which, therefore, do you prefer?' Without hesitation I chose the horse, whereupon a useful young 
animal was purchased for twenty-five sovereigns. I used him in business, and was supposed to get one day a fortnight with the hounds. I had plenty of falls, but nothing serious, and by degrees, as one horse was lamed or worn out, he was 'promoted' to the plough or harrow on the farm.

Years rolled on, and it so happened that my native town became a centre of sport, and the fame of the fertile Vale of Aylesbury spread far and wide as a steeple-chase and hunting district. I formed at that time, with the assistance of two wellknown sportsmen, over my Prebendal farm, what was considered and is still thought to be, the best natural course in England. I had then married, and these two gentlemen, noticing that I had many a fall with the hounds, protested that my life was then too valuable to be trusted to the class of horse to which I had been accustomed; would I allow them to send me a nag worthy of the country, and of such superior manners that I should feel comfortable in negotiating the Aylesbury ox-fences and doubles? I agreed, albeit as they rode horses for which they were in the habit of giving from 250 to 300 guineas each, I was rather afraid of the deal. However, they knew my means were somewhat limited, and that I could not afford a big price. One morning, as these two gentlemen were going to meet Lord Lonsdale's harriers, in a lovely hunting country, the clattering of a horse's feet attracted my attention. I looked round, and saw a railway porter leading into the yard a horse carefully clothed up, with a 


\section{26 RECORDS OF OLD TIMES}

hood and breast cloth on. He said it was addressed to me, and had just arrived by the London and North-Western train. When placed in the stable and unclothed, we all three uttered an exclamation of astonishment at the sight of so faultlessly beautiful an animal. It is useless for me to attempt a description which would satisfy me, but the mare stood just over sixteen hands high, colour a rich dark-brown chestnut, almost a black, black legs, brown muzzle, rather a big head, carried beautifully, slightly lopping large ears, fine prominent eyes, broad forehead with white star in centre, a rather long neck, with a black silky mane, magnificent shoulders well laid back, strong loins, a bang tail set rather high up on the rumps, tolerably wide hips, bang and strong drooping quarters, splendid hocks, good forehand, deep chest and ribs, famous feet, critically she had rather weak pasterns, yet springy and elastic. She was in the pink of condition. Here, then, was apparently everything one could desire. As there was ample time to join the meet, which was distant about four miles, I hastened to get into my boots, leathers, and hunting costume, and started. On examining the direction label, I found attached a short note from 'Harborough Brown,' a wellknown heavy-weight cross-country rider and manager of Mr. John Anderson, of Piccadilly (not my old friend 'Joseph' of 'that ilk'), saying 'he hoped I would like the mare, and that the price would not frighten me, as it was fifty guineas!' (Fifty guineas! she looked more like three hundred); that she was 
the perfection of a hunter, six years old, and could carry thirteen or fourteen stone over anything that any horse in England could do, "but that she made a little noise'; no roarer, 'but whistled a bit; and if I took care not to press her too hard in deep ground I should never discover it.'

My two hunting patrons, with myself, jogged on to the meet. It is superfluous to say I tried my new mount in all her paces, and found her simply perfect ; she walked like 'me grande dame,' and as most good judges will say, 'if they walk well, they can do everything else well.' Although I was not a bruising rider, I could go fairly well to hounds, and was anxious to see how the new purchase performed, which I could do much better if some one else in whom I had confidence rode her first. On arriving at the meet, a hare was soon found, and after going over a few fields, with some moderate fencing, which the mare jumped faultlessly, we killed our hare, and as the mare pulled a little, everyone came round and were astonished at her beauty and the style of her performance. I asked an old friend of mine, T. W. Morris, of Bedgrove, a light weight, and one of the best men I ever saw across a country, to exchange mounts with me, as I wished to see her perform with a really good man on her back. He consented, and we trotted on with the hounds, to commence that most unsportsman-like act, viz. to hunt a "bagman' or bag fox. This was the practice at that time with Lord Lonsdale, and the sport with this pack produced some of the most 
remarkable runs on record in Aylesbury Vale. We trotted on to Drayton Mead, about four miles distant, and found the fox had been despatched about a quarter of an hour, and the hounds were at once laid on. I should mention that although the hounds of this pack were called harriers, they were draft hounds from many of the best packs of stag and fox hounds in England, being for their original business being somewhat undersized. The foxes were brought from his lordship's estate, Lowther Castle, in Cumberland, and after proper care and training in some barns at Tring, were taken in a box to the open country and turned down to provide sport in the vale, nearly three hundred miles from their birthplace. Generally these 'red rovers' went away wildly at a tremendous pace. On this occasion reynard took a fine line of country over the best part of the vale, and the pace was terrific. My friend soon took the lead, knowing the country well, and, as he told me afterwards, found himself quite at home on the mare; and that although he had had some clever horses, he never rode so brilliant a performer as this. I saw him come to the Broughton brook or mill head, so famed afterwards in the great steeple-chase won by Vain Hope, ridden by W. Archer, the father of the celebrated Fred, Jem Mason, of 'Lottery' fame, coming in second on the 'British Yeoman.' The mare cleared it magnificently, and after passing to the south of the town of Aylesbury, the fox took a line over a very severe country, and when the dusk 
of evening set in, my friend found himself alone at Tythrope covert, about two miles from Thame, having about seven couple of hounds with him, and the fox lost! - not a soul but himself being in sight. The pace had been so severe, and a stinging brook at Ford, four miles back, with about sixteen feet of naked water, which the mare skimmed over like a swallow, had stopped old Jem Morgan the huntsman, whippers-in, his lordship, and many others, who mostly got a ducking, or had shied it, and then found a bridge. After the fox was lost Mr. Morris returned, getting together such hounds as he could, and when returning for home, about a mile, met poor old Jem, who had the remainder of the pack with him, and was wondering what had become of the fox and the leading hounds. The finish was about nine miles from my home at Aylesbury, and about eighteen from the kennels at Tring, the country run over nearly fourteen miles. The new hunter and her rider returned in triumph to her stable, and was none the worse for the run. A very disagreeable event happened to myself which prevented my seeing this extraordinary finish. Whilst lost in admiration at the splendid performance of the new purchase, I was riding in as good a place as I could, and, jumping a fairly big fence, I did not perceive on the landing side that there was a great well-rotted muck-heap of at least fifty tons. My horse landed into it, almost up to her shoulder-blades, which sent me flying over her head, and I fell plump on my back into the soft manure, completely 
saturating myself with the unpleasant liquid. I was obliged to relinquish the chase, and was thereby deprived of any further opportunity of seeing $\mathrm{Mr}$. Morris's ride. This eventful run, and the brilliant performance of the new investment, was naturally talked about. For myself, having seen how grandly the mare went, and how perfect was her style, I was more than content with the deal.

In sending a cheque to 'Harborough Brown,' I asked him for some particulars of her history, and found she had been bred in the Melton Mowbray district, and was got by Belzoni out of a perfect hunting mare. This horse was noted as the best sire of natural jumpers throughout the Midlands. After having been carefully taught her business, John Anderson bought her, when rising six years old, at a high figure, and sent her down to an order from Mr. Wilson, the then master of the 'Atherstone,' for 250 guineas. He being rather a little man, and this Belzoni mare being sixteen hands high, and somewhat fidgety on being mounted, he disliked her, and, on finding she made a slight noise, he returned her, and I thus became her owner. I remember one day, after meeting the Bicester hounds at Chilton village, a fox was found at 'Chinkwell Wood,' near Brill Hill. The pack raced him away to the New Wood at IVotton. The squire (T. T. Drake), hunting his own hounds, rattled away as usual, cheering on his pack, and, going down the hill at a great pace, charged a big ox-fence, and got safely over. I was near to him, 
and did not like the look of this 'bullfincher,' but in the fence was a strong five-barred gate. The mare was pulling hard, I was in a good place, thought it could not be worse if I charged the gate. I got my heart up to the sticking-place, and launched her at it. It seemed to me as though she never went out of her stride, for she cleared it like a bird, without touching it. The hounds had a check at the wood, and many hard men came round me, and said they never saw so desperate a jump, as it was on a steep descent, and they were prepared to see a very bad accident; but the way she negotiated so dangerous an obstacle was beautiful to behold. If there was one thing this charming animal felt more at home with than at any other whilst hunting, it was a brook of naked water. The well-known Jem Mason wished to try her, and took her one day in cold blood at the River Thame, and she cleared it without the slightest difficulty - twenty-three feet of water. On one occasion, when I was showing the gentlemen of the 'Varsity' over the Broughton course on my father's farm, we came to the water jump, which had a plain sheep hurdle before it. The intending riders, who were walking, pronounced the brook impracticable, and refused to have it in 'the line of country.' Amongst the company was Lord Coventry, Mr. Allgood (Captain Barlow), the champion rider of the 'Varsity,' and others, who remonstrated with me, and suggested that this part of the course should be altered. I was riding my mare, and said, 'Well, I don't think you ought to funk this water jump, if 


\section{RECORDS OF OLD TIMES}

the mare I am now riding, who is only a common hunter, can jump it without whip or spur in her snaffle bridle.' To this they assented, as they felt sure she could not accomplish the feat. I dismounted, as I did not mean to settle the point myself, and requested my neighbour, Morris, before mentioned, to show the way. He thereupon mounted her, took the mare round about 300 yards, shook her up, set her going, and over she flew, landing on her hind legs clear of the water, and without a flaw in her stride. After this they did not venture to object, with their trained steeple-chasers. I may, however, mention that in the result every one of the fourteen starters got into the brook, and floundered about, to the amusement of the lookerson. A Mr. Goldingham got through first, on a horse called 'Tough Tom,' and in the end won the race. On measuring the space cleared by the mare, we found it to be twenty-nine and a half feet !

I could easily fill a small volume with an account of the splendid hunting career of this beautiful mare, but, omitting further reference to her prowess, complete my story with a description of the singular illness she suffered from, and her tragical end. From one cause or another, something unaccountable happened to her, which was perhaps unprecedented in the ills to which (horse) flesh is heir. A fistulous gathering settled on the top of her withers, just where the neck springs from the shoulders. This became serious, and I called in an experienced veterinary surgeon, the eldest Mr. Lepper, 
and, as the suppurating matter could not escape, and the discharge continuing, an opening was made beneath the skin low down in the shoulder, about sixteen inches below the wound, a seton was passed through, and a vent found for the discharge. After a time it was discovered that the bone was diseased from being so long in contact with feculent matter, when with great dexterity and courage Mr. Lepper actually sawed arvay two pieces of the spinal process, each as large as my thumb. Eventually, after more than six weeks of unremitting care, the bone became sound, the wound healed, and the patient found no detriment whatever from the operation. It destroyed, however, much of the mare's beauty, as it formed a hollow depression nearly an inch in depth, and three inches in length, close to the point of her fine shoulders. The celebrated V.S., Mr. Major, saw her afterwards, and said it was an unique operation, and one of the most successful he had ever witnessed. I rode her for nine seasons, never having had a fall, when one day, in a run with the Baron's hounds near Aston Clinton, the pack was going at a good pace towards Buckland, when I jumped a small fence out of a paddock, and landed in a rather boggy place. The mare struggled out, and, after going over another fence into a big grass field, began to kick most violent'y, which she had never done before. On dismounting, she seemed perfectly mad: her eyes flashed, she was striking out viciously with her near hind leg, whilst I had the greatest difficulty in 


\section{RECORDS OF OLD TIMES}

holding her. Mr. Lepper was on ahead, and I managed to let him know; so, with the help of two farm labourers, who were working in the field, succeeded in getting her led home, nearly four miles. She was at once slung upon a beam in the stable, and, after a careful examination, it was discovered that she had split the os calcis-the bone forming the cap of the hock, which keeps the large muscles and sinews coming down the thigh to the fetlock in their place. The splintered bone scraping against the tendons and sinews every time she stepped caused such pain, that she kicked out violently to get rid of it, which made it worse. After being slung, her hind feet just touching the ground, the poor sufferer became quiet, and in some weeks' time we managed carefully to let down the slings, and she could then stand; she very soon began to walk, but it was manifest that she would never jump again. She became useful as a delightful hack about the farm, and to take journeys of three or four miles at a steady pace. The accident happened at the beginning of the year, when in the month of April I sent her to Mentmore for service to 'Hungerford,' a rather small, very stout horse, and one of the soundest on the turf in England. The following year she produced a lovely filly foal, a rich dark-brown chestnut. When about three weeks after the birth of the foal, which was trotting round its dam in the rickyard, the mare became somewhat excited, suddenly was seen to stagger, foll down, 
and never moved afterwards. On a post-mortem examination it was found that she had actually broken her heart, as the aorta had been burst, and death was instantaneous! I had some of her silky mane preserved, and one honf mounted in silver as an inkstand. Thus tragically ended the career of one of the best hunters a man ever possessed.

Misfortunes did not end here. With great care and attention we brought up the foal by hand, which throve and grew into a great beauty, but smaller than her distinguished dam. I very carefully reared her, and, when rising four years old, thought the time had arrived to make her useful as a good hunter. She was broken and well handled, and showed herself to be a fine mover, with all the grace and good temper of her mother. One day, when down at the homestead, I found this filly had broken out of the field, got over the brook, and jumped a fence into a neighbour's enclosure. I sent round one of my men to bring her home, when he discovered that some mischievous boys had driven her into a rickyard, and had hunted her round under pretence of driving her home, when she sprang at a gate, struck the top rail with her knees; the rail broke, one of the splintered ends entered her chest, pierced her heart, and she fell dead in the yard! I never believed in breeding what are called 'nag horses'; there is so much risk that it is scarcely worth the anxiety; but a good cart horse, even if he accidentally became blemished, can earn his living 


\section{I36 RECORDS OF OLD TIMES}

on a farm-at plough or harrow-after he is two years old. Since the Shire horse and Hackney have now their special societies and exhibitions, the science of breeding and rearing is greatly advanced, and horse breeding has become a profitable business. 


\section{CHAPTER XIV}

Curious instance of life insurance- $\mathrm{X}$., a specially fortunate speculator in freehold property-His remarkable purchase of life interest of a younger son of a peer-Death of the earl, of the heir, with other cleaths-The younger son heir to the earldom and 50,00ol. a yearEnormous windfall to $\mathrm{X}$. - His noble generosity to the impecunious peer-His attempt to insure his life-Unwarrantable refusal to appear before the company's doctor-Sudden withdrawal of proposal by X.-The end of X.'s career.

There are probably many very curious experiences of the practice, advantages and otherwise, of life insurance. Having been for more than fifty years the local agent of one of the leading offices in London for both fire and life assurance, there have been several remarkable instances which have come to my knowledge of the practice of this valuable system of thrift and perhaps forced economy. The following statement is so unique and so incredible that I might have some reluctance in committing it to writing, if the principals who appear in it had not gone to their long home. I, however, refrain from giving names, in consideration of those persons to whom the story relates. Well, then, the father of $\mathrm{X}$. was a solicitor with a good country practice, who was highly respected throughout the county wherein he resided. He had several sons, and the subject of this singular story was the second, who was brought up to his father's profession. He was 


\section{${ }_{13} S$ RECORDS OF OLD TIMES}

shrewd, intelligent, sharp, and eccentric. Entering the legal profession on his own account, he obtained two or three remunerative appointments, and otherwise his practice throve, and he began to accumulate property. He was remarkable for 'nosing out ' and dealing with properties which had depreciated in value. He had an especial penchant for substantial country mansions, to which some land was attached, and he invariably succeeded in disposing of such a property shortly after his purchase at a considerable profit. In addition to keeping a look-out for such investments, he had a keen eye for the judicious purchase of life annuities, as also life interests. I doubt whether in the annals of life assurance one could meet with a chapter more extraordinary than that respecting a life interest which $\mathrm{I}$ am about to relate. $X$. heard that a son of one of the most distinguished members of the House of Peers was in great pecuniary trouble, and was desirous of selling his life interest in the family estates, the property being strictly entailed. The applicant's father, an aged man, was living, as also was the heir to the peerage and to the property, but unmarried. The latter, however, was of middle age, and well and hearty. The second son was also a strong robust man and married, but without children. As to the central figure of this romance (for it is one), he was in robust health and likely to reach a good old age. It was this third son whose life interest $\mathrm{X}$. bought, giving 13,000 l. in cash for it, with no proviso whatever, except that the whole property 
should become his, with such encumbrances as existed at the time of purchase, on the vendor's entering into possession of the estate. In less than a year afterwards the aged peer died, and the eldest son succeeded to the property. The second son died from the result of an accident, leaving no children; shortly after the eldest son passed away, leaving the third, whose interests $\mathrm{X}$. had purchased, the unexpected heir to a title with scarcely a shilling to support it. He was married, with a son to succeed him. This was a terrible position for him to be placed in. $\mathrm{X}$. found himself in possession of an income of fifty-six thousand pounds per anmum. He was of a most generous and impulsive nature, and when the trustees of the estate sought an interview-which was readily granted-and laid the sad case before him, stating that here was a peer of ancient lineage, representing an earldom, totally without any income to sustain his position, he replied that he saw the sad and deplorable position in which the earl was placed, and offered that if they would repay him the original advance, with the legal expenses, and interest at 5 per cent. from the time of purchase, a sum amounting to nearly is,00ol., he would give up to them half the incone. He therefore sacrificed 28,000l. per annum, so as to enable the peer to live and maintain his position. The only condition he made was that the earl should promote in every possible way the insurance of his life, so as to enable X. to retain his income in the event of insurer's death. 


\section{I4O RECORDS OF OLD TIMES}

It was at this time that I appeared on the scene. The old friend of my boyhood sent for me to meet him at the Law Institute in Chancery Lane, and after we had luncheon together he told me the whole story, and consulted with me as to the best means of carrying out the life-insurance project. I suggested that I should communicate with the actuary of the office, of which I had been for many years one of the country agents, and report to him the result. After I had obtained the necessary information, I proposed that we should meet at the office and endeavour to arrange the business, which was probably a matter of unprecedented magnitude-at any rate for a single office to undertake. After the appointed conference it was arranged with the actuary that the usual medical examination of the earl should be made, and in the event of a favourable report, a sum of $170,000 \mathrm{l}$. should be insured on his life. The office, as is the practice with all the leading establishments of the kind, divided this large sum by agreement amongst several others of like repute and standing, as but few offices ever risk more than $20,000 /$. on any one life.

Then trouble arose. An application to the earl to wait upon the physician for examination was refused. This refusal to keep a mutually agreed upon appointment was so utterly unexpected and so unfair, after the sacrifices that had been made in the noble earl's interests by $\mathrm{X}$., the latter was naturally most indignant. He felt he had been left in the lurch. The earl then suddenly left England to travel on the 
Continent, to, as it appeared, evade the responsibility he had undertaken. His conduct was inexplicable, and $I$ believe that up to the last no explanation of it was given. Nothing daunted, however, the insurance company despatched an eminent physician with instructions to follow his lordship, and to endeavour by constant association with him to make such a report upon his habits and general good health as should warrant them in making the proposed insurance. As it was a matter of pecuniary importance to me, as the agent to the office, who would receive my commission on the payment of the annual premiums, I assisted by every means in my power in carrying out these inquiries. Our doctor followed him up incognito, and succeeded, after some weeks' research, in finding him (also incognito) in Switzerland, where he had settled. There the M.D. associated with him at his hotel and various places, and in due time made a report, which was entirely favourable, as to the fugitive's health and general habits. Thereupon the necessary papers were prepared. X., of course, was much gratified at the result. Now, the annual premiums would have amounted to over $5,000 /$, yet there would be clear income left, after this paid, from a property realising nearly 20,000l. per annum.

Now for another surprise. When the time came for the completion of the contract, $\mathrm{X}$. himself was missing. Week after week passed, and at last the actuary of the office discovered that he had resold the life interest to the family for a very 


\section{RECORDS OF OLD TIMES}

considerable sum, but less than half the amount it would have realised had the insurance project been carried out. The chagrin, disappointment, and just indignation which the authorities of the various offices felt, that they had thus been made to appear so foolish, may be conceived. Although $\mathrm{X}$. and myself often met afterwards, he studiously avoided the subject. I, however, discovered that, not satisfied with the splendid coup he had made, that he had made another gigantic purchase, and projected a scheme which would absorb all the money he could raise. This was to buy a fine estate, with splendid mansion, with a noble deer park, farmery, extensive stabling, lovely gardens, and every appanage to a great county residence. This property was near to Slough station, in Bucks, on the Great Western Railway. X. had formed a club for high-class people, ladies being included, with a racecourse, polo, skating on the lake, and every possible allurement for fashionable life. He appointed a wellknown sporting lord to preside over the proposed Isthmian games, with a charming old Elizabethan residence in the park, near the celebrated churchyard of Stoke Poges, made famous by Gray's immortal ode. A race meeting was arranged, the day fixed, and all fashionable London was agog to visit it. One important duty had, however, been overlooked, that of 'police,' with the exception of two or three ordinary county police, who were attending at the mansion. Not a soul was in the park for the protection of visitors. A party of 


\section{A CLEVER CLEARANCE}

'roughs' had been organised for plunder, who, with impudent ferocity, stopped all visitors, and deliberately held up their arms, robbed them of their watches, jewelry, and every farthing they possessed, and then decamped. The mob also broke into the refreshment tents, devoured and drank everything they contained, and, in short, plundered the place, leaving it quite desolate. Owing to this disastrous beginning the club obtained a bad name, no one frequented the park, and the scheme broke down.

An amusing incident subsequently occurred. A firm of well-known upholsterers had furnished the club, sending down splendid suites of furniture for both reception and bed rooms, with kitchen requisites, and everything necessary for a grand establishment. I have heard on excellent authority that the amount agreed to be paid was $17,000 \%$. After the fiasco of the race meeting, and the evident failure of the whole scheme, the upholsterers in secrecy organised a midnight campaign, and as soon as daylight vanished upwards of twenty of the largest furniture vans departed by various routes from London to Slough, and before midnight they were concentrated at the entrance of the Park, proceeding from thence to the mansion. Before daylight every van was loaded, and the procession on its way to its destination, bringing every vestige of furniture and equipments which the house contained. With such secrecy had the expedition been managed, that the noble lord in 


\section{I44 RECORDS OF OLD TIMES}

charge of the establishment, when he arrived at his office in the mansion in the early morning, found the place a barren desert, no desk on which to write, nor a chair to sit upon! It has never been satisfactorily cleared up to this day what were the causes that led to this sudden denudation of the mansion, but it was said that it was done with the connivance, if not at the suggestion, of $X$. Thus ended the great Sporting Club and Racecourse. Mr. X. died about three years since, leaving behind him a fairly handsome fortune. De mortuis nil nisi bonum. He was a generous, charitable man, as the Orphan Asylum at Slough can well testify, as upon several occasions he contributed some thousands of pounds to its funds. 


\section{CHAPTER XV}

The Date Coffee Company-Discovery of the value of the date as an infusion equal to the best coffee - Successful flotation-Establishnent of the patent-Manufacture of date coffee at Kurrachee in IndiaThe I maum of Muscat--Rapid increase in the consumption-Handsome profits - The French patent and its sale-Flotation of German company-Sudden collapse of the sale of the article through the action of Mr. Gladstone, Chancellor of the Exchequer-The Date Coffee Company in the Law Courts-Final break-up of a company whose $5 l$. shares had for some time been quoted at $37 l$.

ABout twenty years ago I was asked by an old friend of mine, Mr. John Tucker, a solicitor in St. Swithin's Lane, to join the board of a company for the manufacture of Date coffee. After having had the matter explained, and on being introduced to the discoverer and patentee of the process, a Mr. Henley, an engineer, and long a resident in India, who gave me a history of his discovery, I was induced to take my twenty $5 l$. shares as a qualification, and was duly elected a member of the board. I cannot remember all the names, but $\mathrm{Mr}$. Henry Hayman was the chairman, and Earl Paulett was a director. I may say that the directors were not to be paid by ordinary fees, but by a percentage on the profits and success of the company. In other words, after the shareholders had been paid 50 per cent. on their shares, they were to receive 


\section{I46 RECORDS OF OLD TIMES}

half the profits beyond that amount. There was a touch of the romance of discovery in the first chapter of the history of this remarkable company. During Mr. Henley's residence in the Mauritius, where he held a public appointment, he gave a dinner party, and after they had joined the ladies he accidentally returned to the dining-room, and was arrested by a strong and pleasant odour of coffee. In reply to his inquiries, his servants told him that no coffee had been made or served. Mr. Henley said he could not be mistaken, and there was the odour. The servants again declared that none had been used. It was then discovered on investigation that some dates, which had been provided for dessert, har been thrown behind the fire, and their burning had caused the aroma of the fragrant berry. He thereupon took some dates, put them into a shovel, and roasted them over the fire, the result affording a still stronger proof of the similarity of the odour to that of the best coffee. Proceeding with his experiment, he crushed the fruit down when dried, together with some of the hard stones, and when the compound was roasted, poured boiling water on it, and made an excellent and delicious decoction, which, it seemed to him, might easily pass for excellent coffee. For nearly two years he employed himself in devising ovens and other apparatus for converting dates into coffee, which, with a mixture in certain proportions of the finest Neilgherry berries, produced a beverage superior to anything of the kind he had ever drunk. He came to 
England, patented his machinery and the process, and erected a small factory in a place at the back of Regent Street, and made the article in bulk. After being submitted to the analysis of the highest authorities, who passed it as superior coffee, it was placed in one-pound tins, and sold in a small way, more as a sample than otherwise, to the public at Is. 2d. per lb. The Custom House, however, soon put a stop to this practice, on the ground that it was illegal to manufacture any dutiable article in England. The company had then been formed with a capital of $50,000 \%$, which was speedily subscribed; and it was discussed by the board whether we should make the article in the Channel Islands, or go to India, or some place where dates were grown, and could be bought cheaply. It was then decided to despatch the requisite machinery, and erect works either at Bagdad or Bussorah, in the Persian Gulf. The machinery was thereupon sent out in charge of a Mr. Mare, a competent engineer, who had been working it in England, and had been very successful in carrying out the process. When he arrived in the Persian Gulf, he found there had been serious riots there with the Arabs, and that several English and other Europeans had been killed by fanatical Mussulmans, with the accompanying destruction of their warehouses and residences. Mr. Mare, therefore, prudently decided not to land the machinery, but to bring it back to Kurrachee, on the Indus, where we had also suggested that our works should be erected. He 


\section{RECORDS OF OLD TIMES}

arrived at Kurrachee, purchased some suitable buildings and land, and set to work. The estate comprised about five English acres of ground near the quay, and contiguous to the railway station. He advised the board of what he had done, and the working capital which he applied for was forthwith provided. Mare found that the best raw material could be procured from the dominions of the Imaum of Muscat, who undertook to supply all we required at a reasonable price, delivered at the works at Kurrachee. The manufacture commenced, and in a few months the ground dates were packed in tin cases, and forwarded to London, where a depôt had been obtained near the arches of London Bridge. There machinery had been erected for roasting and grinding the Neilgherry berries, also for mixing the date powder, and packing the product into canisters. In this form date coffee was sold by the pound to the public at $1 s .2 d$. and $1 s .6 d$. per $1 \mathrm{~b}$.; the former containing $\frac{3}{4} \mathrm{lb}$. dates, $\frac{7}{4} \mathrm{lb}$. Neilgherry, and the best quality half of each. The next stage followed in due course. Advertisements appeared, imposing placards being placed on prominent hoardings, grocer agents were appointed, and a most prodigious trade set on foot. The initial demand far exceeded our most sanguine expectations, and the consumption rapidly rose to three tons per week, whilst in the space of a few months it reached seven tons weekly! Everyone who drank the beverage was delighted with its fragrance and delicious flavour, and there were eminent medical authorities who pronounced 


\section{FOREIGN DATE COFFEE COMPANIES I 49}

it more wholesome than even the pure coffee berry itself. Many persons are compelled to give up drinking ordinary coffee; it does not agree with them; but everyone could with impunity drink date coffee. The profits were large, and it was then decided to take out patents for all European countries, and for America and the Colonies. When these patents were secured, we brought out the first subsidiary company for France, with a capital of $75,000 \%$, and sold this company our patent for 50,000/. The shares were eagerly taken, and the first great profit to the parent company commenced. The shareholders received 50 per cent. or half their capital back, and as the directors were to receive their percentage, $2,500 l$. was divided amongst them. I myself received nearly $400 \%$, besides the dividend on my shares. Works were erected in Paris, and business commenced there. Our enterprising chairman, whose zeal was apt to outrun his discretion, began to negotiate for the sale of patents in other countries. We had offers of $25,000 /$. from Russia, and negotiations were opened involving $30,000 /$. for Austria, 50,000/. for Germany and her dependencies, 25,000/. for Italy, 20,00o/. for Spain, and, wonderful to relate, 20,000/. for Turkey and Egypt. But the crowning absurdity, if I may so call it, was entering into an arrangement for a consignment of the patent to the United States and Canada for 1 20,000/!

A meeting of shareholders was called, and held in the large room of the Cannon Street Hotel. The 
hall was crowded, many ladies being present. I may remark that we were all astounded at the statement of our chairman, and-our shares rose 500 per cent.! Our original $5 l$. shares were sold readily at $25 l$. each, and were still rising in the market. It was then agreed to bring out the German company like the French, at 75,000l. in 5l. shares-50,000l. for us, and 25,000/. for establishment and working capital. In forty-eight hours after our prospectus was issued 67,000l. was subscribed. Now began our troubles, and I venture to think we were most cruelly and unjustly treated. It appeared that in our prospectus for this German company there was a statement to the effect that the German patent had been granted, which, in fact, it had; but our solicitor was not aware at the time that the instrument, after being granted, had to lie at the office in Berlin for six weeks before it could be ratified, so as to give anyone an opportunity of lodging an objection to the specifications. As we felt perfectly confident there could not be any valid objection to it, we proceeded to allotment, as the whole capital had been applied for, and a premium of 2 . a share was at once offered. A friend of my brother's, a man well known on the Stock Exchange, one Ffarrington Bellairs, asked me to obtain him an allotment of a hundred shares, and when they were allotted he paid the deposit and received the shares. It now appears that certain wreckers on the Stock Exchange, who are always found when necessary, had discovered the fact as to objections to the German patents. A 


\section{MR. GLADSTONE AND COFFEE 151}

few days before the expiry of the stated six weeks, some futile objections were raised, which, of course, stopped our proceedings. At that time our original 5l. shares were quoted at 37 . The German company was paralysed, the subscribers claiming a return of their deposits, and declaring that they were not liable for calls. Mr. Hayman strained every nerve to stem the torrent without avail. Although works had been erected at Hamburg, and twenty tons of dates were in the docks with which to commence operations, we offered to pay back the deposits to all who demanded it. About 35,000l. was withdrawn, but we had such confidence in the manufacture, and in the demand which would ensue, that we determined to persevere. There was, however, a greater crush to follow. To our astonishment and indignation, Mr. Gladstone, who was Chancellor of the Exchequer, in his budget speech that year announced his intention to stop the sale of all substances of any description coming in under the name of coffee, other than that produced from the real berry. He proved to his own satisfaction by trade statistics that whereas the consumption of tea had advanced enormously, that of coffee had stood still, therefore the revenue was suffering greatly by the consumption of extraneous substances, which were being mixed with the real berry and paying no duty. He therefore proposed to absolutely prohibit the sale of such compounds under a penalty of $100 \%$, and that no retailer should sell, either as a mixture or otherwise, any substance under the name of coffce, other than the produce of the coffee 
berry. This seemed very fair and reasonable, especially as a protection to the revenue. But here was this just and honest reply, vtz.: "That ciery" ounce of date coffee brought into England, paid through the Custom House the fullest amount of duty, precisely the same as Ceylon, Brasitian, or produce from any' other country!' The fact was, the Mincing Lane people had got hold of the right hon. gentleman, and, inasmuch as we were somewhat interfering with their trade, had placed this disgraceful and most unjust proposal before him. A meeting of our directors was called, and as I happened to be a personal friend of the late Sir Charles Du Cane, then chairman of the Customs, the Board deputed me to wait on him, and learn the real position of matters. I went, therefore, to the Custom House, and was met by the worthy baronet with his habitual courtesy. In the course of our interview I was informed that what we had stated was true, namely, that three or four tons of ground dates were passed weekly by us through the Customs, paying the full amount of duty, the same as the prodice of the coffee berry. Mr. George E. Russell, who was one of the subordinates of the Ministry, and represented my native town of Aylesbury in Parliament, although I had been his bitter but unsuccessful opponent at his election, received me very cordially, entered upon the subject at once, and promised to make every inquiry. I then waited on several other members of Parliament, who all expressed their utter astonishment at my information, and promised to oppose 
Mr. Gladstone's proposal. A few days afterwards a meeting was called in the tea room of the House of Commons (a most appropriate place), where I was introduced to Sir Wilfrid Lawson, who informed me of his determination to oppose the proposal, as he thought it was a heavy discouragement to the consumption of a valuable and pleasant beverage, and a substitute for alcoholic liquor. Mr. Gladstone postponed the consideration of that part of the budget which received violent opposition, and it was not until July that the confirmation of his proposals was passed with some modifications. Still in the result very heavy penalties were enacted, quite sufficient to deter the greater portion of the trade from selling duty-paid date coffee. In the meantime the consumption fell from tons to cwts. week by week, so what with this, the German fiasco, and the collapse of the trade, together with the lawsuit brought by Mr. Ffarrington Bellairs for a return of his money and exemption from calls on his shares, the destruction of this marvellously successful company was effected. The Bellairs trial came on in due course before Mr. Justice Lopes, and, I need scarcely observe, was eagerly watched by the people of the Stock Exchange, who were very jealous of a company that had achieved success without their assistance. Chiefly, I believe, through the eloquence of Sir Charles Russell-now Lord Russell of Killowen-with his masterly management of the case, plaintiff obtained a verdict, although we, the directors, considered it was dead against the weight 


\section{I54 RECORDS OF OLD TIMES}

of evidence. The verdict, with costs, came to over $600 /$., which proved a heavy blow to us, as, in addition, our own costs exceeded $400 \%$. We then moved for a new trial before the Lords of Appeal, who, after a very short hearing, not only quashed the proceedings, but ordered the verdict to be entered for the defendants! Thus the payment of the costs had to be reversed, and the company were released by the payment of a nominal sum. But the mischief had been done since the purchase of the other patents fell through. The chairman, Mr. Hayman, the patentee, Mr. Henley, and one other director had died, so that our once famous 'El Dorado' was put to an end, and the public were deprived of a wholesome digestive beverage, and all in consequence of the unfair and unjust proposals of $\mathrm{Mr}$. Gladstone. The land, buildings, and works at Kurrachee were sold, so that with the produce of a sale of the very substantial and handsome furniture, with large turkey carpets in the rooms used as board rooms on the first floor of the Palmerston Buildings, in Old Broad Street, enabled the directors to pay all the liabilities of the company. Thus perished this once prosperous undertaking. 


\section{CHAPTER IVI}

Capital punishments - Crimes of every description that were punishable by death-Numbers at every assize left for execution-Banks and the two $\mathrm{C}_{1}$ ibbs for horse stealing-Sheep stealers-The new dropBaron Garrow-A hanging judge-John Thompson at Maidstone -Instance of superstitious belief in the charm of the dead hand - Mislaid death-warrant found, and years after sentence woman taken from wash-tub and hung.

IT is almost impossible to understand at the present time the blood-thirstiness of the law in respect to capital punishment, or the sentence to death. A large number of crimes, now considered comparatively frivolous, for which short terms of imprisonment are deemed sufficiently deterrent, were then punished with death. I perfectly remember when a boy hearing that dreadful sentence being pronounced against a young man named Saunders for a burglary with violence, but nothing out of the common run of such offences, and he underwent the extreme penalty of the law. My father's residence was next to the old Bucks County Prison, in the town of Aylesbury, and in front of this gaol were the Courts of Justice, and I had frequent opportunities of hearing trials at the assizes, and oftentimes, as was then the custom, of visiting prisoners under sentence of death. I recollect on one occasion seeing five men who had been sentenced to death at that 


\section{I56 RECORDS OF OLD TIMES}

assizes, or general gaol delivery, two being for murder, and three for horse stealing. They were all hung. The two former richly deserved it ; their conviction was for taking the lives of an old man and his wife, who kept a turnpike gate, the house of which had been broken into and the takings of the gate stolen. The three horse stealers were found guilty of taking a horse scarcely worth seven pounds. Those poor fellows at the present day would probably have been punished with six or nine months' imprisonment with hard labour. I have also known men hung for coining and forgery. The drop, or gallows, was erected on an iron gallery, about thirty feet above the ground, in front of the county gaol, in the open market square, where at least three or four thousand people could witness the sentence carried into effect; and when any notorious criminal was hung, all the windows in the square were occupied, and a charge in many cases made for seeing 'the sight.' When I was a little boy, I remember Baron Garrow, the judge at one assizes, condemning twelve men to death-two for murder, three for horse stealing, those already mentioned, and seven for sheep stealing. These last were reprieved, and their sentences commuted to transportation for life. They were sent abroad, and I don't think any of them ever came back again. They were all agricultural labourers; and never did an assize pass without the capital sentence being recorded against eight or ten poor fellows for agrarian robberies and other crimes. Arson was punishable with death, 
and many suffered the extreme penalty of the law. The sentence of 'death recorded' was generally commuted to transportation for life, or for seven, fourteen, or twenty-one years. Highway robberies were fertile causes of the death punishment. Towards the close of the sixteenth century, I find that in 1596, forty persons were executed for robberies in Somersetshire alone. Thirty-five were burnt in the hand and thirty-seven whipped, and many other counties had the same record. This year no less than thirty human heads might be seen on London Bridge exposed to public view; they belonged to various malefactors who had been decapitated for certain crimes, mostly for those called high treason. 1 read also that in 1652 , on May 10 , a woman was publicly burnt alive in Smithfield for the murder of her husband; and on September I 2, I686, William Hawlings, and his brother Benjamin, a few days afterwards, were executed at Lyme, as being concerned in the 'Monmouth ' conspiracy. They were greatly pitied, and were the grandchildren of William Kyffin, a leading preacher among the Baptists. On June 4, 173I, a man was executed for forgery, being the first occasion of a death punishment for that crime.

On March 3, i752, Elizabeth Jefferies and a man named Swan were executed. The latter was dragged twenty-seven miles on a hurdle drawn by six horses, whilst Jefferies rode in a cart. They started from Chelmsford gaol at 5 o'clock A.M., and arrived at Epping Forest, the seat of their crime, 


\section{${ }_{15}$ RECORDS OF OLD TIMES}

and were hung at two o'clock. On May 8, r 784 , James Till, a lad of about seventeen years of age, was hung at Oxford for robbing his master of seventy guineas. He had been twice reprieved, but could not obtain a pardon. And on the 27 th of the same month John Thompson was executed at Maidstone. He was a young man, and had committed a highway robbery on a Mr. Phillips, near Seven Oaks; he had had two reprieves and had great hopes of mercy until the Sunday before, when his death-warrant came down. He bore his disappointment with great patience and resignation, and had his coffin placed in the cart, and was attended by the chaplain. He owned he deserved death, and desired all young men to take warning by his untimely fate. He was destitute of work as a water-gilder, and fell into the hands of a fellow who persuaded him to go on the road, where they committed several robberies. After a dispute, they parted, and-he, Thompson, was taken. He was of poor parents, but of genteel appearance, and used to say that his pride and vanity in dressing beyond his means added greatly to his ruin.

On April I 7, 1758, John and Walter White, who were respectively twenty-three and twenty-five years of age, were hung on Kensington Common for breaking into the house of a farmer, Vincent, of Crawley. They laid their ruin to an accomplice who decoyed them from labouring work, telling them how easily money was got by thieving. The following incident, showing the superstitions of the 
times, occurred at their execution. While the unhappy fellows were hanging, a child about nine months old was put into the hands of the execu. tioner, who, nine times, with one of the hands of each of the dead bodies, stroked the child over the face. The child had a wen on one of its cheeks, and the notion still prevailed, that on being touched by the hands of a dead criminal, who had been hung, the disease would be cured. In the same month a remarkable circumstance occurred. A young Grenadier, aged twenty-seven, was shot at Plymouth for desertion; he had been sentenced by a regimental court-martial to receive five hundred lashes, and on appealing against the sentence to a general court-martial, instead of confirming it, they condemned him to death. On April 4, 1764, at the assizes at Monmouth, a young girl, about eighteen years of age, was burnt alive for murdering her mistress. It seems incredible, but I find that at the March assizes at the Old Bailey no fewer than five were sentenced to death; one for forgery, and four for burglaries and robberies-one of them, a boy of fourteen years of age, for stealing a silver watch and nine guineas. The first four were hung. And at the same assizes fifty-six were sentenced to transportation, one to be privately whipped, and six to be branded.

On March 30 , some desperate fellows broke into Aylesbury gaol to release two prisoners named Berry and Turner. They broke through the roof and succeeded in freeing the two men, who had 


\section{RECORDS OF OLD TIMES}

been capitally convicted, and the whole party got away. There were some extraordinary cases which I cannot forbear mentioning, as at Durham there were two cases of pressing to death in 1576 and in I597; and so late as the year 1770, at the Old Bailey, a prisoner charged with murder refused to plead, when he was shown the apparatus for pressing to death, whereupon he pleaded 'not guilty,' was tried, convicted, and hanged. The object of his refusal was to prevent the forfeiture of his estate for the benefit of his heir.

There was a remarkable occurrence in December i772. A man named Richard Holt was murdered at Bierton, near Aylesbury, at night, in his bedchamber, by Corbet, a rat-catcher from Tring. He was tried at the Bucks assizes, and condemned to be hung and gibbeted at Bierton. Great crowds went to the execution. It came out in the evidence that the murderer entered the house by the chimney, and left in the same manner. Unknown to him, his dog had followed him to the house, and in the morning he was sitting outside, and could not be driven away; the dog was known to belong to Corbet, and this led to his conviction. In 7866 a man was hung at Newgate for robbing another man of his hat, which had a handkerchief in it. This year several were hung at NewgateG. Woodward, for stealing Lord George Cavendish's horses; W. Smith, for coining a halfpenny-benefit of clergy not being allowed; and Phobe Harrison, for coining shillings. She was hung, and after 
hanging half an hour, they placed faggots round her body, and consumed her to ashes. On April 20, I 787 , fifteen convicts were hung on the new drop at Newgate. Amongst them was Wm. Trapshaw, for breaking open in the daytime the apartment of Jas. Sinney, and stealing a linen gown and an apron. Probably at the present day he would have had a month's imprisonment. Of six criminals left for execution in November 1799 , two were only twenty years of age, two were eighteen, one fourteen, and the youngest only twelve. I have not been able to discover if these children were executed, nor have I ascertained for what crimes they were convicted. I mention them to show how bloodthirsty our criminal law was at this period. As another instance, I find that on December I7, I799, at the Old Bailey, twenty-six convicts were sentenced to death! thirty-three to be transported for seven years, seven to be imprisoned in Clerkenwell, five to be publicly whipped, and two to be whipped and discharged. This was indeed a general gaol delivery.

At the next summer assizes at Aylesbury, Henry Richardson, for robbery at Langley Marsh, and $\mathrm{Wm}$. Brown, for breaking into a house at High Wycombe, were sentenced, and both hung at Gallows Road, Aylesbury ; and 'Galloping Dick,' a famous highwayman, was also hung at the same time. Several of these crimes were, doubtless, of great atrocity, but most of them would be considered minor offences at the present day. I have often heard a story, which has never been contradicted, 
that in the beginning of the present century a woman had been found guilty for some trifling offence, the penalty for which was death, and she was sentenced to be hung at Aylesbury. By some accident the warrant for her execution had not been sent to the High Sheriff, and she continued in prison for some two or three years, and performed the ordinary work of washing in the gaol. It was the custom at that time for prisoners to be allowed, as a favour, to go out to the private houses in the town, and do ordinary household work. Some years after her condemnation, some officious clerk, in looking through the records of the Home Office, discovered that the warrant for her execution had never been despatched. It was therefore forwarded at once to the sheriff for due process. It was, after some time, discovered that the miserable woman was still living. The governor of the prison found she was out in the town washing, when one of the turnkeys waited on her at the wash-tub, and said, "Well, missus, you be to be hanged. The warrant has arrived at last, and we must carry the sentence out not later than to-morrow morning:' 'Werry well, then,' the poor woman replied, 'I suppose I must go '; so she washed the soapsuds off her arms and hands, and departed with the official, and was hung the next morning! This statement has been vouched to be true, and was told me by a man who knew the circumstances. 


\section{CHAPIER XVII}

Witchcraft - Its extraordinary superstitions-Biblical authorities-Joan of Arc-The Puritans-Henry VIII.-Sir Matthew Hale-Ducking at Castle Hedingham-Ruth Osborne drowned at GubblecoteVerdict of murder-Conviction and execution of Colley-Susanna Hannocks at Wingrove weighed against the church Bible-Visit of the Fiery Drake to Aylesbury Gaol-Prognostication before the assizes of death sentences.

THE extraordinary superstitious belief in witchcraft and sorcery is not to be wondered at in Protestant England, when we remember what we read and are taught in our Bibles. For example, in Exodus xxii. I 8 it is decreed, "Thou shalt not suffer a witch to live, and Saul consulted with the witch of Endor 1056 B.C.; and in 1484 A.D. Pope Innocent VIII. issued a bull against witchcraft, under which it is recorded that of innocent persons a thousand were burnt, and many killed by the tests which were applied. The burning at the stake of Joan of Arc is a horrible instance of this superstitious belief. In $\mathrm{I} 520$, a great number were burnt in France, when one sorcerer admitted having I,200 associates. Between the years 1580 and 1595 900 were burnt in Lorraine; a hundred and fiftyseven were burnt in Wurtzburg, both old and young, learned and ignorant, between I620 and 1627 ; and we are told that one Grandier, a priest 


\section{RECORDS OF OLD TIMES}

of London, was burnt on a charge of having bewitched a whole convent of nuns in 1634 . Even in America the belief existed, and at Salem, in New England, nineteen persons were hung by the Puritans, eight more condemned, and fifty confessed themselves to be witches, and were pardoned. As late as the year 1775 , at Kalisk, in Poland, nine old women were burnt for having bewitched, and thus rendered the land unfruitful in that Palatinate. It is, therefore, not surprising that this superstition should have existed in England. As a matter of fact, we find that Henry VIII. enacted that witchcraft and sorcery should be felony without benefit of clergy. Barrington estimated the judicial murder for witchcraft in 200 years as having reached 30,000 ! Sir Matthew Hale burnt two persons for this crime in 1664. Seventeen persons were burnt at St. Osyth, in Essex, about 1676, two witches were burnt at Northampton in 1705 , and five others two years afterwards; whilst at Huntingdon, in 1716 , Mrs. Hicks and her daughter, only nine years old, were hanged. In Scotland it is asserted that thousands were burnt in Ioo years. The laws had lain dormant for many years when, it is said, that some ignorant person attempted to revive them by finding a bill against a poor old woman in Surrey, and they were repealed in 1736 ; and even so late as September 4, I 763 , a poor paralysed old Frenchman died, in consequence of having been ducked as a wizard at Castle Hedingham, in Essex; and similar cases have again occurred. 


\section{DUCKING A WITCH IN HERTS 165}

It seems scarcely credible that almost within living memory such beliefs could have existed, and such terrible cruelties practised, as were perpetrated upon poor defenceless old women, and that even courts of justice should have employed themselves to sustain this miserable superstition. Such, however, was the case. I find that in $175 \mathrm{I}$, on April I 8 , the town crier of Hemel Hempstead announced that, 'On Monday next, a man and a woman are to be ducked at Gubblecote, near Long Marston' (which place 1 know well), the same notice being cried at Leighton and at Winslow. On April 20, in accordance with the notice given by the criers in various other towns, Ruth Osborne was ducked as a witch at Gubblecote. Both Osborne and his wife had fallen under the suspicion of the mob on account of some supposed witchcraft. As in the case of Sir John Long's witch, the crime of this poor old couple, in the eyes of the rabble and the local Bumbles, was possibly the fact that in their old age they might become chargeable to the parish. The Tring overseers, learning that the brutal and ignorant mob intended to impose the swimming test on the old man and his wife, made some attempt to protect them in the workhouse, but on the mob threatening them, surreptitiously they placed them in the vestry of the church, believing that the sanctuary would be respected. But even this precaution was unavailing. The mob, raging for blood, burst open the door, seized the poor victims, and assaulted them in a most merciless manner. The accused were 
repeatedly dragged through a pond, till the old woman died in the hands of her inhuman tormentors. A hulking rascal, who had acted as ringleader during the fatal outrage, actually went round amongst the spectators and collected money for the 'sport' he had shown them! The life of the old man was with much difficulty saved. Such a terrible outrage could not be overlooked, and this occurred so late as the middle of the last century, when our lawgivers were beginning to lift up their voices against this grossly superstitious and obnoxious statute. Three men were apprehended and tried for this frightful outrage. Two were acquitted, and the other, named Colley, was condemned. On July 30 , this William Colley was convicted at Hertford assizes of wilful murder, and was sentenced to be hung at the place where the murder took place, and on August 22 he was executed. He was brought from Hertford the first day to St. Albans, and then to Tring, and on to the place of execution. He was guarded by 108 men of the Horse Guards Blue. Crowds travelled for miles round, and there was a large concourse of spectators. I have heard a description of this miserable spectacle from old people who were present.

Some stories, well authenticated, have their ludicrous side. On February 2S, 1759, Susanna Hannocks, an elderly woman of Wingrove, which was only about three miles from Gubblecote, was accused by a neighbour of bewitching her spinningwheel, so that it would not go round, and offered to 
make oath of it before a magistrate, on which her husband, in order to justify his wife, insisted on her being tried on the church Bible, and that the accuser should be present. Accordingly the woman was taken to the parish church, where she was stripped of all clothing except her shift and undercoat, and weighed against the Bible, when, to the mortification of her accuser, she outweighed the Holy Scriptures, and was honourably acquitted of the charge!

On October 28, 1762, a number of people surrounded the house of John Pitchers, at Langdon, in Kent, dragged out his wife, believing her to have bewitched a boy named Ladd, thirteen years old. They compelled her to go to the boy's father's house, forcing her into a room which the boy already occupied, scratched her arms and face in a cruel manner, in order 'to draw the blood of the witch,' and then threatened to swim her. They were, however, prevented by some of the less barbarous spectators from proceeding to this extremity, and the poor woman's life was preserved. As to the persons concerned in carrying on the imposture, particularly a man named Beard, with Ladd's wife, they were taken before a magistrate, who compelled them to make compensation to the alleged 'witch.' The nob then dispersed, and the country became quieted. The boy, who, of course, was 'in it,' pretended to void pins and needles from his body, and his father and mother collected money from people whose compassion was excited by the melancholy story. At the winter assizes of 1769 it 
appeared that witchcraft was still believed in, as at Cambridge a farmer was punished for throwing a witch into the water, and otherwise maltreating her. In Ireland the law was put in force against Anne Lawler for bewitching John Keating, but before any proofs could be commenced the witch escaped. These circumstances seemed to be remnants of the previous century, as on March I I, 16 I8, two women, of the name of Flower, were burnt at Lincoln for the alleged crime of witchcraft, on their own confession ; they were condemned by the Chief Justice of the Common Pleas, Sir John Hobart. Witchcraft, combined with astrology, often gave rise to tales of remarliable occurrences, which were traced to the former heinous crime, as I find on May 16, I669, 'a fiery drake' had been seen near Thame. It appeared to be as long as All Saints' steeple at Oxford. It made the place light enough to read by, gave a report, and vanished into sparkles. It used occasionally to visit Aylesbury Gaol the night before the assizes, and was called 'the Wat.' It would then make its appearance like a small flame, and the unfurtunate person who saw it, looked forward to certain death. Why Aylesbury Gaol should be so distinguished does not appear. 


\section{CHAPTER XVIII}

Early steeple-chasing-Qualities of a good steeple-chaser-St. Albans in $1833-34-$ Aylesbury - Noderate stakes-The rise and temporary fall of the Aylesbury meeting-Y'oung ' Oxford' at Aylesbury vice Banbury, abandoned-A tremendous line of country-Twice across eighteen feet of naked water and over a turnpike road-C'Grief'Well-known cross-country gentlemen riders at Aylesbury-Their hardihood and pluck-A cruel course and unjumpable fence-A carefully laid-out line at Aylesbury-Abuses and their reform-A great meeting-H.R.H. the Prince of Wales prevented from being present-A defaulting official-The late Earl of DarnleyReminiscences of 'Varsity steeple-chasing-Assumed names of the riders-The disguise stripped off by 'Bell's Life' - Bishop Wilberforce and the steeple-chases.

A GREAT deal has been written, and many more or less conflicting statements have been made concerning the actual origin of the steeple-chase. It is not my intention to enter as a controversialist into this very debatable question, but as one of the oldest sportsmen connected with the truly athletic exercise, I may be allowed to give my own practical experience, and to recount the part I have played and the scenes I have witnessed in the pursuit of this great popular cross-country sport. I believe there is no better test of a man's true courage in the saddle than can be supplied by a successful struggle in a good steeple-chase. The chief elements of success are, Ist, great courage; $2 n d$, a cool nerve; 3 rd, good 


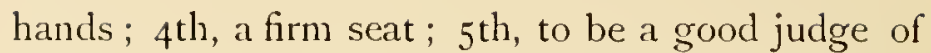
pace; and 6th, and above all, a fixed determination to persevere to the end, despite of accident or other casualties. Many a race have I seen won when apparently all chance appeared gone; the ultimate victor had had a bad fall, but he had resolutely remounted, persevered, had seen one opponent after another come to grief like himself, but, left literally. possessor of the field, he cantered in almost alone. These remarks are chiefly applicable to the old style of steeple-chase over a natural course, and have no reference to the 'make-believe' cross-country races now seen at the recognised gate-noney meetings, over artificially made fences which characterise them. Not but what excellent sport, with clever horsemanship, is to be seen at such gatherings. But they lack the continual variation and unexpected changes of success that attended the old style, such as is yet preserved at the Liverpool and the Aylesbury meetings, which are almost the only two natural public courses left.

Amongst the earliest of these contests I find there had been a well-managed race about the year I $833-34$ at St. Albans, when a strong field of noted horses met, and the race fell to 'Moonraker'; and in I 836 the Aylesbury steeple-chases commenced.

A great contrast to modern times for these early sporting events was the amount of the stakes for which they ran; these seldom exceeded 50l., with perhaps a sweepstakes of 20 sovs. P.P. - no forfeits, the second horse saving his stake. After these 


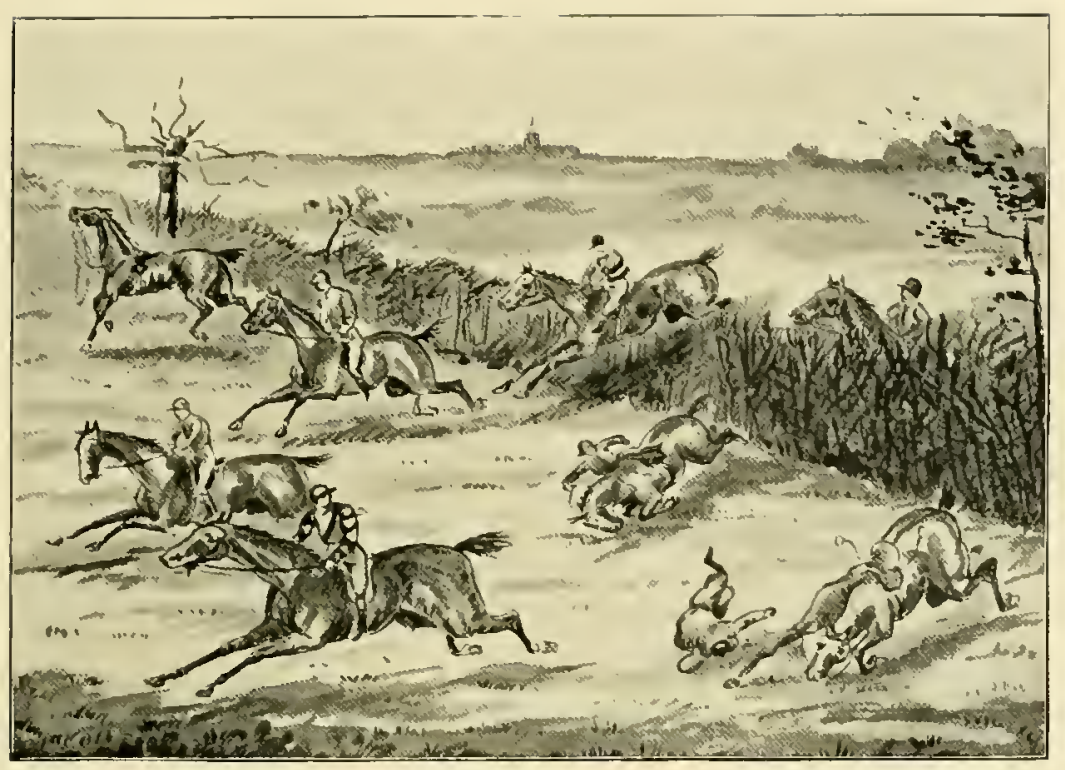

STEEPLECHASE, OLI STYLE, AYLESBUTY, 1847

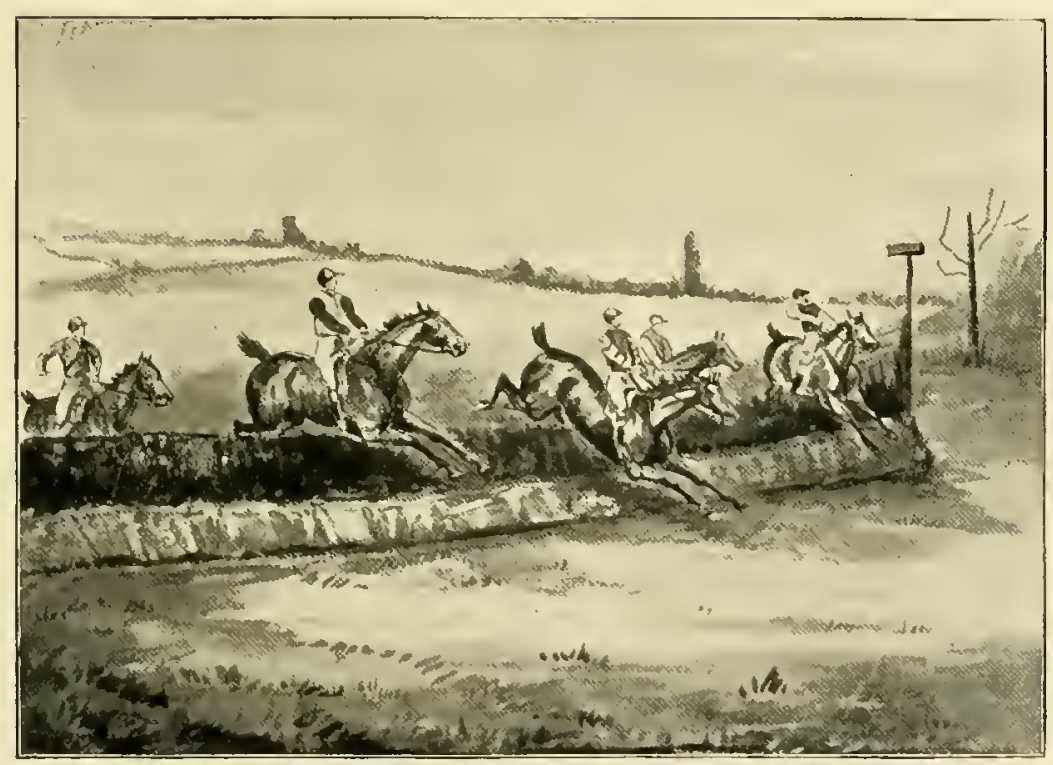

STEEPLECHASE, NEW STYLE, LINGFIELI, 1897 

highly successful contests a few sporting inhabitants of the town and neighbourhood of Aylesbury formed themselves into a committee to organise an annual meeting; and as the district had then become well known for its splendid lines of country, and as many non-residents kept their horses for hunting at Leighton Buzzard, Winslow, Tring, Bletchley, and also in the old town of Aylesbury, a fund was raised to pay expenses, and to compensate the farmers over whose land the horses ran. Somehow or other it leaked out that for two or three years the compensation money had not been paid, and that debts had accrued for printing, with other expenses, and that no audit had ever been made, nor had any accounts of moneys subscribed been rendered. Thus the meeting flagged, and the interest subsided, so that for a period of two or three years no races took place. When the racing here had absolutely died out, a circumstance occurred further a-field that led indirectly to its revival. There had been a dispute over some races at Banbury, which were held by the members of the colleges at Oxford, and consequently the undergraduates decided never to go there again. I was present during the discussion, and was asked if I would undertake to find them a line over a fair hunting country in the vale of Aylesbury. I promptly agreed to comply with their request, and in the following year, 1846, arranged for a course over a fine grass country close to the town, with a rattling good jump of eighteen feet of naked water, which had to be crossed twice. The line had one drawback, 


\section{I72 RECORDS OF OLD TIMES}

it involved crossing the turnpike road to Bicester. I may add, however, that in those days such an obstacle was little cared for. Indeed, as the steeple-chases then were practically from point to point, it would have been difficult to find four miles of country anywhere without public roads of some sort occurring in the selected line. I chose a line at my father's farm at Broughton, which was about two miles from Aylesbury on the Tring road. The course was most severe, the fences being uncut, the water jump was the mill stream forming the mill-head, where it had been carried about three feet above the adjoining land, so that the horses had to jump it uphill. The water could not be seen till they galloped close up to it ; the landing also was two feet below the stream; the banks were very unsound, and although the water was not more than twelve feet wide, it was a very formidable and dangerous obstruction. Many horses came to grief at this unsportsmanlike obstacle, but this was thought to be a great merit in a line of steeple-chase in those days, it being considered to be good sport to get a horse down. Two immense doubles of whitethorn, nearly eight feet high, with two wide ditches, had also to be negotiated, whilst bullfinchers of great height and strength were the order of the day. Rarely or ever did a horse get over the course without a fall or accident of some kind. It is needless to say that the four miles was well done, if it took no more than from sixteen to twenty minutes to cover the distance.

I can remember many of the names of men who 
distinguished themselves over this and similar courses at that time. One gentleman, with whom I have only lately had many a pleasing conversation on those hard-riding times, is Mr. W. Beach, M.P. for one of the divisions of Hampshire, a gallant good sportsman, and very useful member of Parliament. He had a severe accident over this course whilst riding a horse called the 'Dean,' being knocked over whilst turning a flag in a large grass field. He was carried into my father's house in an unconscious state, in which he remained for some days, but then recovered, and was removed home. I remember a very severe race between the rival jockeys, Messrs. J. Allgood (Captain Barlow) and Burton, now of Daventry, who rode two well-known chasers, Zanga and Spangle. Approaching the last fence into the winning field together, at a terrific pace, both rose simultaneously at the fence, which was a moderately cut single. They cannoned in the air, and the pace they went threw both horses down, the riders being flung with great force in opposite directions. They were carried away insensible, and the 'Captain,' after a few minutes, recovered his horse, remounted, and struggled on, just managing to stagger between the flags, and was declared the winner. Whilst mentioning that a dangerous fence was thought to be absolutely necessary in those days to make a good steeple-chase course, I recall a typical instance which belongs to the period before I took an active part in steeple-chasing. At that time there was generally but one race, or at the most 


\section{I74 RECORDS OF OLD TIMES}

two in the day, and those who selected the line arranged that the farmers' race should start from a hill at Pitchcott, about six miles from the town, and should finish in a small enclosure about two miles from Aylesbury. In fact, it was near to the very spot where Old Vivian, ridden by the veteran 'Martin Beecher,' finished and won, with Grimaldi, of St. Albans fame, ridden by Dan Seffert, second. The last fence into the winning field was actually unjumpable at any time; but after a horse had bustled along for four miles, probably with more than one fall, it need not be wondered that this fence should be designated 'a corker,' under the mistaken idea that it tested the staying powers of a 'chaser.' The race was for 100 ., given by Baron Rothschild for farmers over whose lands the hounds ran-70l. for the first horse, $20 \%$. for the second, and Iol. for the third. The course was only marked out by one flag occasionally placed in a hedge, which was to be passed on the right hand; the riders were to find their way over the line as they best could. There was no showing them the course beforehand. It is almost impossible to give credence to the description of a natural course in those days, especially from those who are accustomed to the well formed and neatly trimmed fences of Kempton, Lingfield, Sandown, et id genus omne, but this last fence should be seen to enable men at the present day to comprehend what a cross-country horse and his rider had to negotiate-which is a very expressive and proper term. After the brook, then galloping 


\section{A DIFFICULT LINE OF COUNTRY I75}

over a rough pasture, they had to cross a macadamised country road (which had just enough ditch on each side, without the exercise of great care on the part of the rider, to throw a horse down), going over about two hundred yards of rough old grass, and arriving at the big double into the finishing field. First, a wide ditch met your view, which must be jumped with a stiff fence in to a wide landing place, with rotten stumps and big elm trees growing at intervals, making it more like a spinney than a hedge; then another fence, with a big yawning ditch beyond, which must be jumped to find a landing-place into the winning field. The finishing flags were placed in this enclosure, which was a level grazing meadow, and were about four hundred yards from the fence. I saw the close of this so-called race, which was won by a horse called 'Vanish,' a useful, racing-looking, well-bred nag, belonging to a farmer named Harris, living at Hampden, on the Chiltern Hills. The winner was so distressed, that, although he managed to jump the first hedge and land on the bank, he could scarcely stand, and some bystanders assisted in getting him into the second ditch, where the rider dismounted, and with further help dragged him out, when he remounted, making a slow canter between the flags and won the race. The second horse then appeared on the scene, was pushed into the first ditch, and fell utterly beaten on the landing; after a few minutes he arose, and, riderless, got into the second ditch, where with difficulty he was pulled out, his jockey mounting, 


\section{I76 RECORDS OF OLD TIMES}

whilst three men on each side propped him up, and the poor brute walked with difficulty between the flags and obtained second money. No other horse was in sight, although twelve had started. After waiting some time, no one else appearing, the judge with his friends left the field, proceeding homewards in a fly. The crowd, both horse and foot, were returning along the turnpike road, which adjoined the last three fields, amongst whom was the veteran John Brown, of Tring, who died about three years since at the age of ninety-three, when some one said, 'Muster Brown, there ain't been anybody claiming the rol. for the third horse.' 'If that's it,' said the old stager, 'I'll have a try.' He rode back with some friends about half a mile, where he had left off beaten, and as his horse had somewhat recovered his wind, he set him going, came up to the terrible double, got safely over, calling upon several people to witness that he had properly gone fairly over the course, and had passed through the winning flags, and claimed the $\mathrm{rol}$. for third money! In the end this was awarded to him. The foolishness of this arrangement, and its cruelty, so impressed me, that I determined, if I had ever an opportunity, the whole of this system should be abolished.

The next year, having been applied to by the ' 'Varsity' gentlemen to find them a course, I proceeded to do so. I considered there was something else to be done besides showing the stamina and capability of a hunter, viz. that the public should be amused, and that the absurdity of a 'point to point ' race, with its impracticible fences, should bcabolished: 


\section{A FAIR HUNTING COURSE 177}

and for the public to be amused, that they should be able to see the race. That the course, if possible, should be near the town, and quite accessible to foot people; that the fences and water jump should be such as men are accustomed to ride over when fairly riding to hounds; if practicable, that the start and finish should be at or near the same place; where a fence was dangerous to horse or rider, it should be made practicable; that the course should be shown to the riders before the race, removing all unfair advantage to native owners or riders, to the prejudice of strangers to the locality; that the finish should be enclosed with ropes or rails, and that horsemen should be excluded from riding on or over the course, as I had repeatedly seen cads absolutely riding amongst the jockeys, so as to be able to say, they had jumped every fence on the line. At Aylesbury there was no charge for admission on to the course except for carriages. It will therefore be perceived, that unless considerable sub scriptions could be found, the stakes and expenses could not be met. In those early days a few farm waggons and carts formed the stands, where a charge of $2 s .6 d$. each was made, which brought in a few pounds to pay labour and petty charges, but the chief cost was met by subscription. There was one peculiarity which redounded greatly to the credit of the farmers over whose land the race took place-they made no charge whatever for the privilege; and if after the meeting a hamper of wine was sent to them, they were satisfied. I have 


\section{I7S RECORDS OF OLD TIMES}

entered rather fully into this matter, as it will scarcely be believed how the gradual development of the modern stceple-chase took place. It may be mentioned that, except special prizes offered by Masters of hounds in the neighbourhood, and men who hunted with them, the cups and otherwise were given by the members of Parliament for the boroughs and counties adjacent. The stakes were moderate, say from $20 l$. to $25 l$, and the entrance money $\mathrm{i} l$. to $2 l$. From one to two races per day, they gradually increased to three, or at the most four, never exceeding the latter number. As, at the time, every course in England was a natural one, it was impossible to fence it in ; therefore there could be but little chance of gate money, and all the expenses came from private subscriptions and the charge for carriages into the winning field. It was a most pernicious custom, prevalent at many races, for men, and even ladies, to ride over the course along with the jockeys and the horses running; nothing could be more prejudicial to real sport than this practice. Often these amateurs would get in the way of the riders, and, as was generally the case, would blunder or fall at a fence, throwing a steeple-chaser down, and thus destroy any chance of his winning. I studiously and effectually put a stop to this practice, by strictly forbidding horsemen on the course, but I permitted their presence in the winning field, if accompanied by a lady. This put a stop to the obnoxious system. When it was proposed that the Grand National Hunt Steeple-chase should come to Aylesbury, it was 
imperative, if they used my course, that the 'Long Meadow,' as it was called, of twenty-five acres, which was the winning field, should be wired and fenced in, with plenty of policemen to prevent people from trespassing without payment of a shilling. There was some difficulty in making the arrangement, as a public footpath crossed one end of the winning field. This trouble was, however, surmounted by appointing four men to hold a rope across the track of the horses, and providing policemen to keep the people moving on. The meeting was a great success, the course was in perfect order, the crowd was immense, and upwards of $1,200 /$. was taken in the two days. The Prince of Wales intended to be present, but was detained at Berlin, on his return from Moscow. Every preparation was made for his reception. The Great Western Railway platform had been !engthened at the station, so as to reach the bridge over the stream into my garden, through which he was to pass to my house, into the main street of the town, where a coach and four was to be in readiness after luncheon to convey him and his friends on to the course. It was a great disappointment, as I had prepared luncheon for forty or fifty in my dining-room for his party, and had to put up with the latter, and no Prince. There were three drags waiting at the front door to convey the distinguished visitors to the scene of action. The sport was excellent. Lord Strathmore rode and won two races gallantly, and Lowlander, the best horse of his year, made his 
appearance over hurdles, being placed third to Lucellum, the winner, and afterwards winning the Royal Hunt Cup at Ascot, and carrying everything before him during that year. I always look on this honest grand horse Lowlander as one of the great racers of the century. I must leave those who interest themselves in racing matters to find the winners in these two days.

I cannot refrain from mentioning one matter of much personal consequence to myself. I will not give the name of the self-constituted manager and treasurer, as he is gone to his last home, but it so happened that he had opened an account with the London and County Bank at Aylesbury. My business manager collected the gate- and other moneys with the stands, \&c., and went, with two policemen in attendance, in a dog-cart, carrying about $600 \%$, after the races, and paid it in to the aforesaid account. The next morning, the manager of the bank called on me, saying he had been privately warned that this gentleman was a somewhat doubtful character, and would strongly advise me to have the second day's money paid into my private account, as I banked with them. I had already made myself responsible for nearly the whole expenses of the meeting, viz., for the police, advertising, printing, labour, compensation for the land, with many other expenses that only racing men know, and I had better make myself safe. I took his advice, and the cash was deposited as suggested. This was most fortunate, as my 
quondam friend seized on the first day's takings, and became very angry at my appropriating receipts of the second day. These enabled me to pay everything, for which I had made myself liable, amounting to over $500 \%$. After I had settled all these claims, I paid the balance into his account, amounting to about 20l. I discovered afterwards that many of the stakes, and his own responsibilities, were unpaid for more than two years afterwards, and I have been informed that some remain unpaid to this day. Moral : "You cannot be too careful in money matters, when dealing with strangers.'

The recent death of the Earl of Darnley (December $\mathrm{I}$ S96) recalls to my mind a very interesting event which occurred in the early history of the Aylesbury Aristocratic Steeple-chases. At the commencement of these races a determined effort was made by the 'Varsity' authorities to put a stop to cross-country meetings by the undergraduates, who had ran at the Moreton-in-the Marsh, Banbury, and other places, and young men had been sent down for disobeying the orders of the Dons. It was therefore found necessary to keep secret the names of owners of the horses running, but more especially the names of the riders. Various expedients were resorted to blind the eyes of the authorities, but none were found more effective than the employment of fictitious names. These, of course, were known to those interested, whilst their masters were kept in ignorance. Often the nom de guerre took the form of a parody on the real name-for instance, 


\section{I82 RECORDS OF OLD TIMES}

Mr. Lance was called Mr. Dart, Mr. Hill was Mr. Mountain ; whilst others, like Mr. Jas. Allgood, who was by far the champion rider in Oxford, was Captain Barlow. It is so long since, that I forget many anusing sobriquets. These fictitious names were printed on the card of the races, as also in the public accounts in 'Bell's Life,' which at that day, i 847 , was almost the only sporting paper published, and that issued weekly, yet the immense authority wielded by this paper can scarcely be credited in the present day. No sporting event of any notoriety whatever, whéther pugilistic, racing, steeple-chasing, betting, card-playing, aquatic, athletic, \&c., was in dispute, but it was always referred to 'Bell's Life,' whose decision was considered final, and was acquiesced in by everyone. Amongst the endless variety of sporting papers-daily, weekly, or otherwise-conducted as many of them are on the most careful and really safe lines, and on eminently high-class literary principles, none of them have ever claimed the authoritative position of 'Bell's Life.' The tacit consent of all parties to the decisions of this paper had many advantages, specially by saving litigation and umpleasant controversy. It may be well imagined how the accounts of the Aylesbury Aristocratic Races were scanned after the spring meeting, when the paper appeared on the breakfast table of many a squire's mansion, or at a clerical dignitary's rectory, to revive the recollections of old college friends at this popular reunion of past and present members of both 'Varsities. Knowing 
therefore, as I did, how absolutely necessary for the future welfare of many undergraduates, that the strictest secrecy should be observed, as to their presence at these meetings, and even more, of their participation in the actual entry of horses and the riding by themselves, I had always given the strictest injunction to the reporter from 'Bell's Life' that no names should be published other than those on the cards. There were, of course, many men to whom the publication of their real names was of no consequence. But to others it probably meant loss of position in their colleges and in many a country home, both lay and clerical. Judge, therefore, of my horror when, on the Sunday following one of our most successful gatherings over my father's farm in the Broughton country, there appeared in this great sporting paper an account of the racing, with much descriptive power, and the names in full of everyone who had taken part in the two days' meeting! The Earl of Darnley, who that year was the head of the sport, was greatly astounded at the publication, and wrote me a most indignant letter, blaming me for permitting so flagrant a breach of his strictest injunctions, and saying it would be the last time they would come to Aylesbury; and that he was authorised to say how seriously the publication of these names would be, and had already been, to those young gentlemen in their future career. It would, he added, matter nothing to him and others, situated as he was, who were more or less their own masters, but that many who were intended for the 
Church were hopelessly prevented from attaining their desired position. I wrote at once to the editor of 'Bell's Life' for an explanation, as I had been very particular in enjoining the most perfect secrecy to Mr. Harrison, who was invariably present at these meetings, who stood high on the editorial staff, and who had hitherto adhered strictly to my directions. I therefore insisted on an apology and a complete exoneration of myself, with a full explanation of the circumstances. Mr. Harrison replied, saying he most deeply regretted it; that he had always been most particular in suppressing the names, but on the morning in question he had been walking over the course, two miles distant, so as to describe it, and had given directions to a deputy to compare the weights on the card with the entries, and when the grooms and helpers had brought the saddles, bridles, \&c., to the intending riders whilst weighing, he had asked the names of the jockeys, and had very officiously put those names into the report in full, and he deeply apologised for what he called his representative's unguarded conduct. I sent this letter off to Lord Darnley, and received a very kind reply and a complete exoneration from him, and the unpleasant affair was ended. After this I took care to impress on all reporters the necessity of strict secrecy in the names of everyone concerned in the 'Aylesbury Aristocratic Meeting,' and the same injunctions to trainers, grooms, and helpers in the stables.

It has often struck me that a list of some of those 
who rode or took a prominent part in these truly sportsmanlike meetings would be of more than usual interest, as very many of them have arrived at the highest positions in the State, the Army, or the Bar. Even the Church has to be thankful for many a good hard-working incumbent who has taken his part 'between the flags.' I have reason to believe the great Bishop Wilberforce took considerable interest in these ' Varsity' meetings. 


\section{CHAPTER XIX}

History of a railway-Opening of the London and Birmingham, now the London and North-Western-The Buckinghamshire-George Stephenson and his son Robert-The Aylesbury-Messrs. Brydone and Rummens-Marquis of Chandos-Mr. Stewart, secretary to London and North-Western-Unfair opposition of landownerContracts and their effect-Directors' advances-The Great Western -The Metropolitan-Purchase of the A and B line-Shameful treatment of the original directors-Their just claims ignored-The Manchester, Sheffield, and Lincolnshire (Great Central).

IT may be of some interest to railway people and others to learn the singular history of a much despised and greatly ridiculed little railroad. I may be pardoned for recounting this, as I was the projector of the scheme for reviving a portion of the original design of old George Stephenson, which was further developed by his son Robert. This line, the 'Buckinghamshire,' was one of the great proposals of the latter in the year 1846 , and was projected to connect the Great Western at Oxford with the London and North-Western at Bletchley, as also to join the former line at Banbury with the latter at Aylesbury, the two lines crossing at a spot now called Verney Junction, in the parish of Claydon, on land belonging to the late Sir Harry Verney. The lines were commenced, and shortly afterwards the railway crisis ensued, and in the end the portion 
from Verney Junction to Aylesbury was abandoned, and was thought nothing of for a space of nearly fifteen years. Sometime about the year i 860 some gentlemen called on me to confer as to the desirability of making a line to Thame, and then continuing it to Oxford from the terminus of the London and NorthWestern at Aylesbury. The line was surveyed, and was apparently sure of success, but 'the old, old story,' want of capital, caused the project to be abandoned. A year or two later, a Mr. Brydone, one of the engineers of the Great Northern Railway, with Mr. F. Rummens, a small and quite unknown contractor, who had been one of those concerned in the abortive railway to Thame, begged of me to join them in reviving the undertaking. I told them it was useless to attempt it, as a Bill had been obtained the previous session by the Great Western Company to make a line to that town and thence to Oxford, but I said, I remember, that in the year 1847 , the portion of the Buckinghamshire (formerly described) had been abandoned, and ought to be revived. The original intention had been to connect Aylesbury with Banbury, Buckingham, and Oxford; but the main line was now like the play of 'Hamlet' with the principal character omitted. The line was, in fact, deprived of all its value. If they thought it worth while, I would show them the country, and prove it would be of incalculable advantage to the whole district if the project could be carried out. I then ordered out a carriage and pair of horses, and we started over the 
line, and I pointed out to them old George Stephenson's original scheme to the north, through Birmingham. We drove to Claydon, saw Sir Harry Verney, who was Chairman of the 'Buckinghamshire,' and when I explained to him my plans, he was greatly pleased, and agreed to assist by every means in his power the object in view. On our return I took them to Wotton, calling on the Marquis of Chandos, afterwards third Duke of Buckingham, fortunately finding him at home, and explained our purpose in coming. He welcomed us most cordially, and expressed himself heartily in support of the scheme, and said he would subscribe 5,000/, and become chairman of the company! As he was then Chairman of the London and NorthWestern Railway Company, this was far in excess of our expectations, and I need not say that I looked on our Bill as safe, and the line as good as made. We arranged for a future conference and returned to Aylesbury.

At a future meeting the preliminary company was formed, the Marquis becoming chairman of the directors, Sir Harry Verney vice-chairman, with a strong addition of some leading county gentlemen, bankers, and others, with myself, the company being duly registered as the 'Aylesbury and Buckingham Railway Company,' afterwards generally known as the ' $A$ and $B$ ' Company. The surveys were made, the Bill deposited, and in 1 S6I our Act of Parliament was obtained. Shortly afterwards the prospectus was issued, the subscription list opened, and 
the estimates having been accepted for the construction-being 100,00ol. for the twelve and a half miles-about $25,000 l$. cash was subscribed, besides a good portion of the land required. The Marquis considered that this was quite sufficient to start with, and the contract was entered into with Mr. Rummens, this to be divided into three portions, the first to begin at Claydon, with a junction to the Bucks line. Sir Harry Verney being the principal landowner for nearly two miles, stipulated that the connection should be called 'Verney Junction,' by which it is still known. This was in I $86 \mathbf{I}-62$. Without any fuss or show, except the consumption of a few gallons of beer to the men, I cut the first sod of the line on my own farm at Aylesbury, so as to make a beginning, but the real work of the road was at Claydon. The want of sufficient capital soon became apparent, and it was found that the bulk of the line must inevitably be made on 'papere', which more or less threw the directors into the hands of the contractor. The reign also at about this time of the Marquis of Chandos as Chairman of the London and North-Western Company came to an end, and Mr. R. Moon reigned in his place. The Sun of the Marquis had set, and the Moon had risen in his stead.

Before actual work had commenced, Mr. J. G. Rowe, our secretary, had received an answer from Mr. Stewart, the then secretary to the London and North-IVestern Company, to his application respecting the support to be given to the ' $A$ and $B$ ' by 
the directors of the London and North-Western. The secretary replied 'that he was directed to inform him that as soon as the line was completed they would be happy to work it on fair and equit. able terms.' 'The Marquis was then chairman of both lines, and he, with our other directors, were of course perfectly satisfied with our prospects. IVe issued $35,000 \%$ worth of 5 per cent. debentures, which were readily taken up by the public, and we thought we were in clover. Soon after the retirement of the Marquis the crisis of $1 \$ 66$ came upon us, and the want of money utterly paralysed our exertions. In addition to this, a London solicitor, the agent to an impecunious landowner, through whose property our line passed for nearly three miles, threw every obstacle in our way, levying blackmail on us by every means in his power, persuading the tenants to put forth monstrous claims for severance and residential injury, and causing us quite a year's delay. This was most unwarrantable, as this same lawyer had welcomed us effusively, promised to give us every encouragement, as the estate would be improved 30 per cent. by having a station upon it, and promised to let us have the land at agricultural value. When we began to treat for the land, as soon as the works had reached this property, this man pretended that the proposed route had been altered, which was utterly untrue, and demanded three times the value of the land, and stipulated that an iron railed fence should be carried along the line instead of a fence of wood and a 
quickset hedge. In spite of his obstruction, the landowner himself living a long distance away, in Bedfordshire, we gave the usual legal notices, and an eminent land valuer arbitrated on the case. He decided in the company's favour as far as the value of the land was concerned, but the delay which this litigation caused stopped the construction of the line for several months, and threw the many arrangements out of gear, until the terrible crisis of I 866 stopped the supplies for more than a year ; the works were almost entirely suspended, some funds were advanced by the bank, and the second portion of the contract was completed. The most important part remained, namely, the last five miles into Aylesbury. The estimate for this work was $30,000 l$, and under the suggestion and by the direction of Mr. Rummens, the contractor, I persuaded the board to issue to him 60,000 . worth of fully paid-up shares instead of $30,000 l$. cash. I am particular in mentioning this in view of the result. The line was then supposed to be completed and ready for opening. Colonel Yolland, the inspector, made a rigid examination, and reported that several things were of necessity to be done before he could certify. The principal items were additional signals and junctions with locking apparatus; these made an extra of 5,000/. The board were greatly troubled at this, as there was no money. The Duke of Buckingham was in India as President of Madras. The Bucks and Oxon Bank agreed to advance the amount on the joint note of the directors then present. I happened to be one, and in 
my anxiety to open the line, I at once consented to sign the bill. The money was found, and the secretary drew out the amount as required for its completion. The line was opened, which then raised the question as to its working; and as the secretary, Mr. Stewart, of the London and North-Western Railway Company, had written, as before mentioned, officially to say that the company would work the line for us on its completion, on fair and reasonable terms, our secretary was directed to apply to them at once to carry out their proposal. It will scarcely be credited that a company of such high repute and position as the London and North-Western Railway should have acted so dishonourably, but they repudiated the whole transaction. Mr. Stewart was dead, the Duke of Buckingham had ceased to hold the chairmanship, and this refusal was then ratified by the then London and North-Western Board. In all my experience I do not know of a more unwarrantable act. I am at a loss to conceive why this conduct was pursued; probably it was to force the ' $A$ and $B$ ' Company to sell their line to the repudiating company. The Great IVestern Company were then applied to, and an arrangement was made with them to find locomotive power, a first, second, and third class carriage, with guard's van, driver, stoker, and guard; our company to supply oil for lighting, with station masters and porters. I forget the exact amount, but I think it was is. I $\frac{1}{2} d$. per mile, about I $3 s .6 d$. per trip, for three trips, a day. I am mentioning these details as a record of 
a poor struggling line. We were all greatly pleased that our efforts had been crowned with success, but the traffic had to be obtained and developed. In this we were thwarted by obstacles created by the London and North-Western at every one of their stations. As an instance, passengers from Oxford, Banbury, Buckingham, or Bicester, who wished to go to Aylesbury, were carried past our junction at Verney to Bletchley, nine miles, then to Leighton Buzzard, seven, to Cheddington five, and finishing another seven miles at Aylesbury, making altogether twenty-eight miles with two changes, when they could have travelled via Verney on the ' $A$ and $B$ ' rail without change for twelve miles; and this was done, notwithstanding every attempt being made by usat all sevenstations, to show the advantages of the new route. I found on inspection that these placards were hidden behind doors and other notices put over them. Coal traffic was diverted for thirty miles after passing Verney junction, and sent to Oxford on to the Great Western broad gauge line. The rates per ton per mile of coal were charged $4 d$. per ton if brought by 'A and B,' and only id. per mile by Great Western Railway; thus, for seven miles to Princes Risbro' 2s. $4 d$. per ton was charged which could be sent by other lines for $7 d$.

Shortly after our Bill had been first obtained in I 862, Mr. Brydone, Mr. Rummens, and myself busied ourselves with an improved approach to London, going carefully over the country, through Wendover, Missenden, Amersham to Rickmersworth, Watford 
and district, also to Harrow and Uxibidge. We projected a line direct to the Metropolis, this having been, as I knew, a part of old George Stephenson's original line from London into the North, but as the authorities at Euston objected, we abandoned it to a future opportunity. It would be useless to attempt a record of the varied fortune which attended the applications to Parliament for a line up this Missenden valley, until at last the Duke of Buckingham and myself persuaded Sir Edward Watkin, with his right hand, Sir Myles Fenton, to join the Board of the 'A and B' line, which in the end they agreed to do, on vacancies being arranged for them. Thereafter the new line was vigorously taken up; and finally, after nearly thirty years of frustrated endeavour, the Act was obtained, and the line conpleted and opened from Baker Street to Aylesbury. And a further development was projected, viz. the bold scheme of purchasing the despised Aylesbury and Buckingham, thus continuing the railway into the North, and joining the Nanchester, Sheffield, and Lincolnshire line. This was looked on as too Utopian for serious consideration, but through the determined action of Sir Edward Watkin, who, as Chairman of the Metropolitan, had succeeded in purchasing the ' $\mathrm{A}$ and $\mathrm{B}$ ' $\mathrm{Co}$. for 100,000l., the line having cost us 167,000 l, and had never earned a shilling for the shareholders, nor had the directors ever received a farthing for their services, or their expenses. This purchase gave the Metropolitan Company an advance of fifty-six miles to the 


\section{DIRECTORS' ADVANCES IGNORED 195}

North, from London. Despite the violent opposition of all the northern lines, assisted also by the Great Western Company, the Act of Parliament was obtained, and the line is now in course of construction, and when completed the new Metropolitan station will be erected in the Marylebone Road, affording an entirely new route into the north by means of the much despised, and well sneered at, condemned little line, immortalised, as it was, as the 'A and B.' Mr. Rummens, the chairman and original contractor, is now gone to his grave, after successfully opposing the honest claims of the original directors, for the advances they had made to construct and complete the line. $\mathrm{He}$, as the largest shareholder, objected to all claims which militated against the value of his shares, and through the quibbles raised in the Court of Chancery lost us many thousands of pounds, depriving me alone of over $4.000 /$ I had the honour of representing this company in the Railway Clearing House for nearly twenty years, and had an opportunity of meeting many delightful, business-like men, as representatives of all the great railways in the kingdom, whose agreeable companionship will never be forgotten by me. 


\section{CHAPTER XX}

Altona-Judge in agricultural department at the great Schleswig-

Holstein Exhibition-My fellow jurors - The officials' utter ignorance of 'management'-Chaos-Assisted by the English exhibitors, orderly arrangement effected-Awards-Trials of implements : difficulties that had to be removed-Thrashing machines: Walter Wood his own driver--He wins the first prize-Horticultural Show at Hamburgh-The success of the English-Liverpool grapes win against all comers-Shabby treatment of the judge-Nonpayment of services and out-of-pocket expenses-Journey homeBorrowing money to get there-Opinion of foreign agriculture-The all-round superiority of English methods.

A T the great exhibition proposed to be held at Altona, in Schleswig-Holstein. I was selected as one of the judges to serve on the jury for live-stock and implements, as representing England. I started on a Wednesday afternoon from home, and as I was to be at Hamburg on Friday evening, I was obliged to travel by the quickest route, and therefore went vi $\hat{a}$ Calais, Brussels, and Düsseldorf. As I could not speak a word of German I had my misgivings as to how I should fare on the journey. However, on entering my railway carriage at Brussels, I found a Herr Lowenthal, hailing from Liverpool, where he had been settled for some years as the representative of a leading German house, who spoke English as correctly as he did his own language. He proved a most agreeable companion, and of great service. 
The country struck me as extremely picturesque, and was otherwise interesting. On arriving at Hanover my companion had to leave me, as he was going forward to Berlin. He urged me to alight for a few hours, when he would introduce me to his friends. I accepted his kind invitation, and was thereby enabled to obtain a glimpse of this very charming city. I had the pleasure of meeting his sister, who had married a cloth manufacturer in Hanover, who had an excellent house, and gave us a capital luncheon. I was conducted through some of the principal streets, and was much struck with the quaint early mediaval architecture, especially with the splendid red brickwork of the houses and chief buildings. The cathedral is very fine, built entirely of red brick, as is also the palace of King George of Hanover, first cousin to our beloved Queen. I was shown a 'bière hall ' of rare beauty, where I drank some very good beer. After bidding adieu to my friend, I started again on my journey, reaching a place called Harburgh, on the southern bank of the Elbe, where we were to be carried over the river on a ferry to an island, halfway across the broad stream. On arriving at Harburgh I was addressed by a polite young man, speaking English well, who recommended me to take a carriage and horses as the best mode of crossing the river towards my destination. He led me to believe that this was the only means of crossing, and ordered my carriage accordingly. I paid him nearly one pound for the journey. On arriving at 
the ferry, I was surprised to find myself packed tightly between two or three omnibuses, carts with merchandise, gigs, and other vehicles, and on arriving at Hamburgh, my carriage and horses trotted me away to the 'Hôtel de l'Europe,' and then I discovered that for about one franc I could have come by either omnibus. But my polite acquaintance had led me to believe that the best, if not the sole, conveyance was in the recommended carriage, for good, if dishonest reasons. He was the owner of the vehicle I had hired, and in that character had plundered me.

Hamburgh is a beautiful city. The chief feature of the place is the lake called the 'Grosser Alster,' near the centre of the city, on three sides of which runs a broad road, planted with avenues of fine trees. Around this piece of water are erected the public buildings, the principal hotels, banks, and theatres. The avenues are thronged with people; the lake (with its flocks of swans) has a fleet of small steamers crossing and recrossing, well laden with passengers. The more populous parts of Hamburgh are on the banks of the Elbe, which is a wide deep river, enabling ships of large size to discharge cargo on the extensive quays. The houses in this quarter are extremely picturesque, and chiefly date from the sixteenth and seventeenth centuries. Some years ago a disastrous fire broke out, and consumed more than half the city. Until then it was the largest ever known since the Great Fire of London in 1666 . Amongst the most 
terrible of the incidental catastrophes was the destruction of the ancient cathedral, which, however, has been replaced by a splendid successor, designed and carried to completion by our ta'ented Englishman, Sir Gilbert Scott.

The morning after my arrival, the English agent, Mr. Shillitoe, conducted me in a facre to the town of Altona, which is about three miles from Hamburgh, and connected with it by the town of St. Pauli, which is a charming suburb. On arriving at the exhibition, I found a very imposing building of great extent. I was presented to Herr Von Postau, the Burgomaster, a most agreeable and intelligent gentleman, who spoke English fluently. I was thereupon introduced to my fellow members, of the jury, amongst whom were Danes, Swedes, Russians, Germans, Hanoverians, and Belgians, about fourteen in all. I myself alone represented England, the French forming a jury of themselves, who kept aloof and stayed altogether at an hotel. This was very strange, although we were in Danish territory, or more properly in Schleswig-Holstein. My brother judges were gentlemanlike men, nearly all of whom spoke English. On entering the show-yard such a scene presented itself as I had never witnessed before. Everything was in confusion. Sheep were placed in pens mixed up with pigs, cattle with horses, poultry with dogs, no evidence of order or arrangement visible from one end of the building to the other. Pens were numbered, but not consecutively, the numbers having been attached without 
any attempt at classification. And there was elaborate blundering as well as confusion. Sheep were in pens under the head of 'pigs,' and, in short, everything appeared in an inextricable muddle. The fact was, that no great exhibition had ever before been held in the country, and there was no one to put things right, or any authority peremptorily directing the whole. Mr. Shillitoe, it appeared, was only manager of the dogs and poultry, and was utterly ignorant of everything else. Fortunately, the late Mr. Clarke, at that time the very able agent to Lord Chesham, with Messrs. Duckering, of Yorkshire pig fame, and a few others who were old hands at our English agricultural shows, were present; so with their assistance we set to work, literally taking off our coats, and put the live stock somehow into order. My fellow judges also assisted to the best of their ability, and by the evening we had reorganised the classes so as to enable us to commence judging on the morrow. That happened to be Sunday, so little was done, and with my English acquaintances we paid a visit to a very charming place on the banks of the Elbe, called Blankenese, a sort of Richmond, about five miles distant. We had an excellent dinner, and after enjoying the lovely scenery, came back to Hamburgh in good time to visit some of the sights of the city.

On Monday we began in earnest. The live stock was fairly good, but the British exhibitors carried everything before them, and Lord Chesham's Shropshire sheep excited much admiration. I was able to 


\section{DIFFICULTIES OF THE JURORS 201}

do some work that day in the implement department. That evening we attended a sumptuous entertainment given to the juries and chief officials by the Burgomaster. Nothing could have been in better taste, and every attention, with due honour, was paid to us by Herr Von Postau and his colleagues. To show the utter ignorance of our Holstein friends of our English system of awarding prizes, they knew nothing whatever of a trial; and when I told them that I should not think of giving a prize haphazard, without a practical proof of the utility of the implement, they were astonished. I was desirous of showing the visitors to the show the value of a thrashing-machine, which only a very few people had ever seen. I prevailed on them to give me a load of sheaves of corn, and the next day put in operation one of Marshall's (of Gainsborough) thrashers, to whom we gave the silver medal. I shall never forget the astonishment of the bystanders when they saw the sheaves enter the machine at the top, and on my catching in my hands the corn as it emerged from the spouts already fit for market, at one operation: their astonishment was unbounded. The same occurred when I persuaded the authorities to supply us with a few acres of standing grass, or clover, to try the mowingmachines. These acres were placed at my disposal, and I was accompanied by most of the judges, including some Frenchmen, none of whom had ever seen one of these invaluable machines at work. When Mr. Walter Wood, the well known American 
inventor, drove a pair of horses himself, and the grass fell down in even swathes before it, I never beheld such bewildered surprise at the efficacy of the machine. We gave it first prize. So it was with other machines, and I am glad to state that our English implement makers reaped a rich harvest from the exhibition at Altona.

There was a most wonderful horticultural show held at the same time on the banks of the Elbe at Hamburgh, which was somewhat of a rival to the Agricultural Exhibition at Altona. Indeed, there existed some rivalry and jealousy between the two places. This show was one of the most splendid sights I ever witnessed. One of the chief attractions was the competition of Hamburgh grapes, for the prize of a piece of plate presented by our Most Gracious Queen, as a compliment to the city, open to all comers. This much coveted trophy was competed for by the principal growers from Italy, Germany, France, Belgium, and even distant Spain and Portugal. But, to their dismay and astonishment, our Mr. Meredith from Liverpool beat them all easily! His grapes, both in size and in colour, were so immeasurably before them, that they could not credit that these could have been grown in a country where the sun scarcely ever shone, and the climate of which was made up of fogs and rain!

During the week my eldest son, John, came over to see me, accompanied by the late Lord Chesham; and as it was doubtful whether I should ever have a better opportunity of either seeing by myself, ur 
showing him, the most attractive features of the Continent, I determined to extend my visit to Berlin. I may add that, notwithstanding the promises of the promoters and leading officials connected with the exhibition, I never reccized one farthing for my' services, not even my travelling expenses, nor the amount of my hotel bill! Needless to say that I left the city with rather unpleasant feelings. We passed via Brunswick to Berlin, visiting Potsdam, and to Dresden and Saxon, Switzerland, returning via Leipsic and Cologne, touching at several of the more famous cities in Belgium, and paying a visit to the field of Waterloo, then via Calais home, with an empty purse. Indeed, had it not been for the kind assistance of a stranger, whom I chanced to meet in Calais, a fellow passenger, I should not have been able to pay my way through to London. Thus ended my Schleswig-Holstein experiences at Altona. I have since heard that it was no uncommon occurrence for English judges to be disappointed at receiving their accustomed charges on the Continent. My advice, therefore, to all my friends is, to have 'the money down ' before they leave home to perform any official function at a foreign agricultural exhibition. My impression is again confirmed, that in agriculture our own country is far in advance, in its practical results, to every other. 


\section{CHAPTER XXI}

Amsterdam-Appointed a judge at the great Exhibition-The journey thither-The Poultry Show-My son Robert wins the gold medals for poultry and water-fowl-Extraordinary weight of prize birdsPaul Potter's bull_- 'A wretch' of a beast-Curious facts in heredity -The famous bull as a picture-Description-The Alderney Bull, by James IVard, R.A._-'Duke of Connaught ' - Trotting matches -Dutch cattle-Milk production and bacon-Tranquil beauty of the Low Countries-The Dutch: their thrift, cleanliness, and industry-The bulb-farms at Haarlem.

Another expedition which I made to the Continent was to an important agricultural show at Amsterdam, where I had been asked to officiate as one of the jurors or judges. I was selected as a member of the jury for 'implements,' more especially in relation to the buildings, appliances, and so forth, employed in poultry-rearing for the farmyard, and in the breeding and cultivation of water-fowl. This exhibition formed part of a more extended one to celebrate the opening of the new public building for a Museum of Art and Manufactures in Holland. My son Robert, who had managed the well-known poultry establishment on my holding, the Prebendal Farm at Aylesbury, was a large exhibitor in live stock, and glad of the opportunity of accompanying me on the journey. We started from Queenborough to Flushing, and hurried on to the "Venice of the 


\section{DUCKS \& GEESE AT AMSTERDAM 205}

North' as quickly as we could. The poultry had been started, via Harwich, a few days in advance. $\mathrm{W}^{\top}$ e found, on our arrival, that they had been delivered the day before, and were in excellent condition. IVe stayed at an admirable hotel, the 'Old Doelen,' which had been rebuilt since I had visited Amsterdam some years previously. I found that the city of Rembrandt was no longer entitled to be called the 'Venice of the North,' with her streets of water, as many of the old canals had been filled up, after large drains had been laid, causing a vast improvement in the sanitary state of the city, and no longer rivalling in its odours the stenches of Cologne, which Coleridge counted. The Dutch Government had been for some years building a receptacle for their art treasures, and as it was now complete, it was decided to open the edifice with a great exhibition for Agriculture, Science, and the Fine Arts. My son, I may observe, was extremely successful, carrying off many prizes, with the special Gold medal for the best collection of poultry, and the same for the highest classes of water-fowl. Such specimens, indeed, had never been before seen in Holland. The Aylesbury ducks, with the Rouens, Pekins, and Cayugas, were matchless, a pair of the Aylesburys weighing $2 \mathrm{I} \mathrm{lb}$. The geese were enormous, a Toulouse gander scaling $37 \mathrm{lb}$, and a goose $32 \mathrm{lb}$., together weighing $69 \mathrm{lb}$.! I was naturally proud of the achievements of my farm.

The arrangements of the show were admirable in every department, and therefore in marked con- 
trast to Altona some years before. One of the great features of the exhibition, of course, was the gallery set apart for paintings and statuary, and was naturally intended for their future reception, and to be worthy of the priceless treasures painted by the most distinguished painters of the fourteenth, fifteenth, and sixteenth centuries. Many of the finest pictures from the Hague, from Haarlem, and other places had been removed and brought into one centre, making a magnificent collection of the finest examples of the painters of the Low Countries. The famous 'Young Bull' of Paul Potter is the portrait of an animal I should scorn to see in any decent herd in England, but I am bound to agree with those connoisseurs who declare the picture to be the perfection of a truly poetic composition. However, the bull, the animal himself, is such a wretch that I would not have allowed him to look over a hedge into the field where my shorthorns were grazing. It is possible that Paul Potter considered him a fairly good specimen of the cattle at the time, as they existed in Holland. It is perhaps probable that the English cattle at that period might have been of the same class. On that reasonable assumption, we may conclude that our cattle have made immense progress since then in shape, colour, and quality. The great attention paid by us for nearly a century in registering our stock in the Shorthorn Herd-book, as also in the Herd-books of other distinct breeds, has tended to create a wonderful improvement in our breeds. Yet, with all our care, remarkable instances 


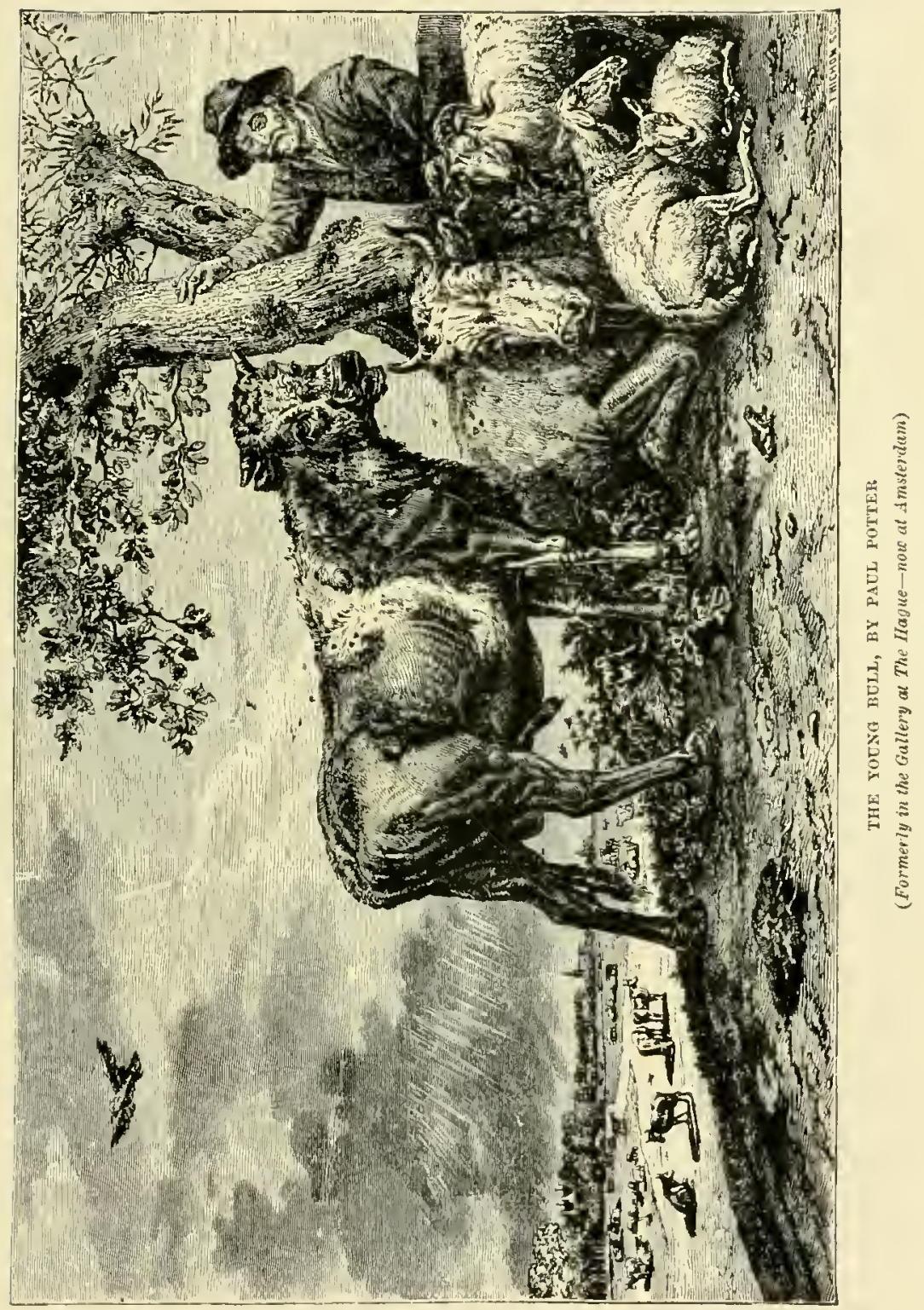



of atavism of types in colour continually recur. For instance, the white face of the Hereford was unmistakably a recurrence to the Chillingham white cattle, which have black noses. The latter peculiarity is sometimes found in animals with the choicest and longest pedigrees of our best lines of blood. It is well-known that the late Lady Pigott, an eminent shorthorn breeder, had found her cattle were yearly getting lighter in colour, with many absolutely white. Complaining of this to a visitor, a first-class breeder, he said that her desire to keep her places perfectly clean by annual whitewashing of the whole of the buildings, inside and out, was probably the cause; and suggested that she should put some red ochre or umber in the wash. This she accordingly ordered should be done, and in three or four years her colours regained their original shade. In fact, 'heredity' crops out in breeding of horses, cattle, sheep, and dogs in a remarkable degree, and peculiarities, after lying dormant for many generations, appear when least expected. I took occasion to deal somewhat exhaustively with this interesting question in breeding, in a paper which I read some years ago at the Central Farmers' Club. Therein I showed the influence of the male animal on the external appearances of the offspring, and proved this by Lord Moreton's cross of a 'Quagga' or 'Zebra' on a thorough-bred mare. The colt was striped like the sire, which markings continued for three generations, the stripes showing fainter each successive year, although the mare had never again been served by a Quagga. 
Our American cousins, utilising my contention some few years ago, determined to cross their own home-bred cattle with Hereford bulls, to provide additional facilities for supplying beef to the Engiish market. When I was judging at the Herefordshire show, I found out that all the young bull calves, of the best breeders, were bespoken for more than a year in advance, at exceptionally good prices, but in four or five years it was discovered that the size of their widely-spreading horns prevented their being packed easily in the railway trucks for Chicago. Consequently the American breeders rapidly dispensed with the Herefords, and they now cross their cattle with the Polled Angus breed, which have equally good fattening powers, but, as their name implies, have no horns whatever.

But to return to our muttons, or rather to our beef. ${ }^{1}$ Paul Potter's bull is a red, poorly-shaped animal, somewhat low in condition, but he has exceptionally good hair on him, and the manner in which that is painted shows extraordinary skill. On the point of his shoulders, where the hair is longest, summer flies are creeping about, and there are flies also buzzing over the back of the famous beast. The bull has his head up, and is bleating to call the attention of some cows in a far off pasture. The saliva is falling from his tongue and his open mouth. He has evidently been licking the flies off his sides, and the marks of his tongue are wet with saliva, and

1 'The Hague, with its splendid Rembrandts and orer-rated Paul Potter.' Henry Stacy Marks, R.A., in Pen and Pencil Skethes. 
appear as fresh as if the bull had just licked himself. Two cows are lazily lying down chewing their cud; close by are two or three sheep, and in the near foreground there is a yellow-skinned frog, wet with his recent visit to the dyke. Leaning over a rail, under a tree, is a man watching the live stock. The atmosphere is moistly hot, and is atmosphere! Yet fine and dexterous as the picture is, one regrets that a nobler bull has not had his portrait handed down to posterity. I do not mean to affirm that a sleek, highly-bred symmetrical shorthorn would have made so perfect an agricultural idyll. But the mongrel depicted by the great Dutch master, Paul Potter, is possibly a painter's, but certainly not a breeder's bull. James Ward, R.A., painted his great picture, the 'Alderney Bull,' which is now in our National Gallery, to rival the bull of Paul Potter. But the style of each work is so utterly distinct that no one could possibly put them together. How totally different is Paul Potter's bull from the beautiful young shorthorn 'Duke of Connaught,' bred by and sold at the Earl of Dunmore's sale, and bought by Lord Fitzhardinge for 4,500 guineas! Immense benefit has been conferred on the Continent by the exhibitions held there of late years. Many of our leading breeders have sent over their cattle, sheep, and pigs, and have invariably come off with flying colours, and have generally sold their exhibits at fairly good prices. When at Vienna I sold my first prize young roan shorthorn bull, 'Royal Geneva,' of the best Bates and Knightley strain of blood, for 1,400 florins 
to Count Polanowski, of Christianople, in Galicia. The public were astounded, as such a price had never before been heard of in Austro-Hungary, but to Englishmen it was a bad price. However, in little more than a year afterwards, the Count wrote to me, saying he believed that the introduction of that sire into his country would completely revolutionise the breed of cattle, as the first cross on their rative herds was most remarkable, and people were sending for his bull calves both far and near.

I was not aware until my visit to Amsterdam that the Dutchmen, like our Transatlantic cousins, were admirers of trotting matches. Yet so it proved. A track of nearly a mile in length had been prepared, with commodious stands for the spectators, one being set apart for Government officials and their friends. To this, as one of the judges, I was adnitted. It was most amusing to see the 'get up' of some of the drivers, or jockeys. Several were fat, burly fellows, as though the weight made but little difference, some weighing fourteen stone, others about eight stone. The jockeys drove with loud shouts, and, amidst the laughter of the spectators, oftentimes came to grief by catching the wheels of their opponents. There was a large crowd of spectaters, which included many ladies in native costume. Altogether, I was pleased with my visit. The people were hospitable, kind, and considerate. The accommodation at the hotels was cleanliness itself, and the 'cuisine' all that could be desired. As to the agriculture of the Low Countries, there is 
but little, as the country is chiefly pasture, but such ploughed land as I saw was admirably cultivated and very clean. The cattle are large, massive animals, with but little quality for meat production, yet deep milkers, often giving twenty to twenty-four quarts of milk per day. But it is of very inferior quality for butter making, being greatly deficient in cream. I believe a well-bred Guernsey or Jersey cow would produce as much butter as two Dutch cows, even if she were but half the size. This accounts for the small number of Dutch cows imported into England. They are almost entirely of one type, black and white in colour, large frames, with hard touch, and not very enticing looking. The sheep are mostly long wools, rather light scrags, and longer on the leg than ours. The Dutch and the Danes are turning their attention to pigs and baconcuring, in which they succeed, and are exporting largely in butter, bacon, and milk, to England. I really love this country, and prefer the flat 'Cuyp' looking meadows, with the lazy cattle stretched out on the rich pastures, the homely and industrious people, and their stolid and imperturbable, yet pleasing and agreeable manners, to the majestic scenery and rugged mountains of the Tyrol and Switzerland. The history and antiquities, the art treasures-including the masterpieces of Franz Hals - cathedral and bulb-farms of Haarlem, which I visited, tempt me to prolong the account of my Dutch impressions. But I must perforce dismiss the subject with a word or two about the bulbs. 


\section{I2 RECORDS OF OLD TIMES}

Acres upon acres of tulips, hyacinths, crocuses, lilies, Sc., are a wonder to be seen and never to be forgotten by such an old amateur as myself. The soil is admirably adapted for rearing the young bulbs, being a soft, mellow sand, and climate moist and mild. 


\section{CHAPTER XXI}

The myths and monastic legends of Buckinghamshire-St. Osyth-

Rip Van Winkle and the Seven Sleepers-The beheading and miraculous restoration of St. Osyth - The Nun's Wood and fountain -Existing local traditions-Sacred wells-'The Holy Touch'Hartwell and Dr. Lee.

MANY parts of our dear old country have their myths and legends, and in the course of my investigations I have discovered not a few stories worthy of preservation. Of all the saints whose lives, both real and apocryphal, have been recorded, none is more curious than that of the devout lady, St. Osyth. Many miraculous stories are told of her, but I am persuaded that there is much truth interwoven with the legends. The faith of the people was so great in her sanctity, that she became one of the best known and best beloved of the holy women of the early middle ages. From the best authorities I glean what a holy life this blessed woman led. The mysterious legend of the saint (Osyth) which I had often heard of in my native district, is clothed with so much dramatic and tragic interest, I have retold it and made it one of the chapters of my book. Before writing of St. Osyth I may, however, remark, that frequently stories and legends crop up which, on investigation, show that 
they originated centuries before they became part of the belief of more modern times. Take, for example, that really touching and beautiful legend of ' Rip Van Winkle.' This is merely a revival of the story of the 'Seven Sleepers,' which belongs to the time of Theodosius, and the conquest of Africa by the Vandals. It is stated that after the seven noble Christian youths of Ephesus had been concealed in a cave, to save themselves from persecution, they fell into a deep slumber, and without injuring the powers of life, they awoke after they had been in concealment for 187 years. On awaking, they thought they had only slept a few hours! and feeling very hungry, they sent one of their number secretly, with orders to return to the city, after purchasing food for his companions. On the youth going to his native city, he could no longer recognise it, and he was surprised at seeing over the principal gate of Ephesus a large cross, and on going to a baker's for bread, his singular dress and his language confounded the baker, and when he offered for payment an ancient coin of Decius, as a current coin of the Empire, the poor youth was dragged before the judge, on suspicion of having found a secret treasure. After mutual inquiries they made the amazing discovery that nearly two centuries had elapsed since they had escaped from their Pagan tyrant. The Bishop of Ephesus, accompanied by the magistrates, and even by the Emperor 'Theodosius himself, hastened to visit the cave of the Seven Sleepers, when they related their story, and on receiving the benediction of the 
Bishop, on the same instant they immediately expired. Here we have a real counterpart, slightly varied, of 'Rip Van Winkle,' which I have always regarded as a most pathetic story; and I shall never forget the beautiful embodiment of the character by Mr. Jefferson, the famous American actor. Wynkyn de Worde, in a book printed by him in 1516 , mentions St. Osyth, and other authorities say that she was born at Quarrendon, in Bucks, about two miles from the county town of Aylesbury. She was the daughter of Frithwald, the first Christian king of the East Angles, and of Wilburga, his wife, who was the daughter of Penda, King of Mercia, who lived at Quarrendon. When very young she was entrusted to the care of St. Modwen, at Polesworth, in Warwickshire. Whilst there, she was sent with a book, from her aunt, St. Eaditha, to St. Modwen, and fell off a bridge into the river, where she was drowned. She remained in the water three days, and was restored to life by the prayers of St. Modwen. She was then betrothed to Sighere, King of Essex, and on the same day obtained his consent to live always as a virgin. Her husband consented to her taking the veil, and gave her the village of Chich, near Colchester, where a nunnery was built, and she became abbess.

The Danes, under Inguar and Hubba, ravaged the country, and because St. Osyth refused to worship their gods, they cut off her head, when, as is reported, she took up her head in her hands, and proceeded to the Church of St. Peter and St. Paul, 
about half a mile away, when she stopped at the church door, which was closed. She struck it with her blood stained hands, when it immediately fell prostrate. On the spot where she was beheaded a fountain of water gushed forth, which was said to cure all diseases. Much of this story is, of course, incredible; but, according to Essex tradition, where St. Osyth's martyrdom took place, was in 'Nun's Wood,' and the fountain still takes its name from the murdered abbess. The body of St. Osyth was first buried in the church at Chich, and was soon removed by her father and mother to Aylesbury, where many miracles were performed at her shrine there. About forty-six years afterwards the body was, by miraculous interposition, translated back again to Chich. In an old Saxon manuscript it is stated 'next resteth St. Osith at Cice, near the see in St. Peter's minster,' where many miracles took place. This saint was held in great veneration. Matthew Paris tells a story of a husbandman named 'Thurcillus,' living at Tistude, in Essex, in the reign of King John, A.D. I 206, who was taken into hell and paradise, where he saw Saints Catherine, Margaret, and Osyth. Amongst the many curious legends of this saint I find that Aubrey states that 'in those days, when people went to bed, they did rake up their fire, make a cross in the ashes, and pray to God and St. Sythe (Osyth) to deliver them from fire and from water, also from all misadventure.' According to local tradition, on one night in every year St. Osyth revisits the scene of her martyrdom, walking with 
her head in her hands. A prayer to St. Osyth is preserved amongst the Cole manuscripts in the British Museum; it is said to have been copied from a manuscript of Edward IV.: 'Sancte Osithe virginis et Martyris tue, Dñe, piis supplicationibus tribue nos foveri, ut cujus venerabilem solennitatem celebramus, ejus intercessionibus commendemur et meritis.' Alban Butler, in his 'Lives of the Saints,' corroborates most of the above records. There was a special office for her at Lincoln, and she was involed with the saints. Her festival was held annually on October 7 , when special indulgences were granted. As before stated, St. Osyth, like many other saints, had a holy well dedicated to her, which Leland describes 'as being at Querendune, betwixt Aylesbury and Querendune, a good mile from Aylesbury.'

There is a well, which I remember, at Dunsome, near that town, which answers to this description. It rises at the back of the farmhouse, and runs through the dairy. The water is of delicious quality, and it never fails through winter and summer. There is scant necessity to remark that 'Sise Lane,' in the City of London, takes its name from St. Sise, or St. Osyth. It may not be out of place to call attention to the great number of wells scattered throughout the kingdom which have miraculous powers attributed to them, wells that are generally dedicated to some saint oftentimes of local celebrity ; many which I have known along the base of the Chiltern Hills, of great purity, springing from the 


\section{I8 RECORDS OF OLD TIMES}

water-bearing stratum of the chalk formation. One of St. Edburg, at Ellesborough, from which probably the village took its name. There still exists a well dedicated to Sir John Schorne, at North Marston, which had great credit for curing the ague. This local saint was a remarkable instance of a corruption of words. The legend was,

Sir John Schorne, gentleman borne, Conjured the devil into a boot.

There are old stone carvings and other representations of this feat, in which there is a large boot, and the devil's head appearing at the top, and his forked tail coming out at the bottom. There is, however, little doubt that the legend means-that the wonderful knight 'conjured,' or ' persuaded,' him into a 'boot,' or an 'exchange,' for some supposed service rendered. Throughout England holy wells exist, many of great antiquity, most of them famed for curing certain diseases. Notwithstanding their sanctity, they were not so efficacious in curing maladies as the 'royal touch,' as was shown by one Wulwin, a Saxon, son of Wulmar, of the village of Nutegershall (Ludgershall, in Bucks), who, after hard labour in cutting down fuel in the wood at Brill, in the neighbourhood, fell into a deep sleep, and lost his sight for seventeen years; and then, upon the strength of it, dreamt that he went round to eighty-seven churches, to beg relief from their respective saints, and at last came blind to the King's Court at Windsor, when he was immediately cured by a touch of the King's hand. Various rites were 
performed at these wells, particularly on Holy Thursday, when they were adorned with boughs of trees, garlands of tulips, and other flowers, and it was customary after service at the church to play and sing at the wells. This is merely an ancient Roman custom, and in ancient Rome 'Fontalia' was a religious feast, celebrated on October 5, in honour of nymphs of wells and fountains. In Britain there are many accounts of holy wells, to which the most extraordinary properties and virtues are ascribed. At some the sick persons were forewarned, if, in dipping a garment in the water, it swam, they would recover, if it sank, they would die. Oblations were always given at holy wells, and visitors conceived that the holy saints could not fail to accept them.

At Hartwell there is a never failing spring of pure water, but, as far as I know, there is no legend attached to it. Yet in after years it may be dedicated to Doctor Lee, who has had it made accessible for his numerous visitors to his teetotal festivals, and has placed over it a stone slab, with the inscription in Greek characters $A P I \Sigma T O N M E N \Upsilon \triangle \Omega P$, which is believed by the common people to be an adjuration to some saint. 


\section{CHAPTER XXIII}

Poultry rearing for profit-Statistics of imports-Breeds that should be adopted-Records of exhibition birds-Major-General Hassard - Pheasant-rearing and the production of pheasants' eggs as a profitable agricultural industry-Remarkable statistics-Prices of eggs-Names of noted dealers--Accounts of profit and lossNumbers of eggs laid and young pheasants reared-Expenditure on the establishment of a pheasant farm.

Amongst the minor industries recommended to be practised by farmers to alleviate in some measure the prevalent depression in agriculture, are poultryrearing and egg-production. I can thoroughly endorse most of what has been said on this matter, but as I have written so largely on this subject, and have appeared as an exhibitor successfully in the show-yard for so many years, I do not feel it either desirable or useful to repeat a more than 'thrice told tale.' Sufficient to say that I believe by a good selection of birds a fairly profitable return can be made, especially if the ladies of the household will give their attention to the undertaking, and they would find it a most interesting and instructive occupation. But their attempts must be supported by their lords and masters, by giving them something better from their granaries than the miserable siftings and defective grains of their cereal crops. 


\section{FOULTRY \& PHEASANT REARING 22I}

They should grant their ladies some portion of reasonably good corn, even if the latter be somewhat damaged, and should furnish them with good housing for the birds, both old and young. For egg production I found Leghorns, of all colours, and Minorcas to be the best layers. The Bramahs and Cochins come on most profitably for winter laying. Plymouth Rocks are hardy strong birds, and Indian game are excellent for crossing with either of these breeds for the table. It must not be forgotten that the Dorking is undoubtedly the best flesh-forming breed, but they do not thrive in all parts of England. They are, however, most profitable on their own native chalk downs, and generally upon dry soils. The Spanish at one time were famous layers, and very white-fleshed table birds, but the breeding for the Iong pendant white wattles and large combs to win in the show-yard, has lost that mostly desired quality, namely, the capacity to produce a large number of very fine pearly white eggs. That the Aylesbury duck is by far the earliest variety goes without saying. They make, for young ducklings about seven weeks old, in March and April, from I 4 s. to 20s. a couple readily. They, however, seem to degenerate after leaving their native district, and a cross is necessary from the original stock every three or four years. The Pekins, a very hardy breed, crosses excellently with the Aylesbury, and gives additional vitality to the young birds. The Rouens are beautiful ducks, not very early, but excellent layers and very hardy. The Cayugas are 


\section{RECORDS OF OLD TIMES}

black, and when first brought to England were large, heavy birds. I was the original importer, and exhibited them for the first time at the Crystal Palace, as also Pekin ducks. With regard to geese I prefer the grey Toulouse, and have exhibited them with great success at many shows. I have won the first prize at Birmingham with a gander weighing 37 lbs., and a goose weighing 32 lbs. The white Embden are beautiful gees:, but they scarcely equal the Toulouse in weight. These cross with the latter admirably. They have one great peculiarity, viz., that the ganders of this cross are almost invariably pure white, whilst the geese are pied or mottled. As to turkeys, the old black Norfolk has almost entirely given way to the bronze Cambridgeshire. I once had a present made me by my old and valued friend, General Hassard, of pigeon fame, both as a breeder and a judge, who, whilst he was quartered with his regiment in Canada, bought a wonderfully fine bronze wild cock turkey or 'gobbler' in Toronto, which had been brought into the city under the arms of a Red Indian, caught alive wild in the woods. He was, without exception, the handsomest and finest turkey ever seen in England; I won several prizes with him, and he scaled 40 lbs. He is, I believe, the progenitor of nearly all the best herds of bronze turkeys at our show-yards. The General is a great authority on prize poultry, and in the early days of the poultry mania bred some of our best buff Cochins. Amongst his brother officers in his artillery regiment 


\section{EGG STATISTICS AND PHEASANTS 223}

he was facetiously called 'Chicken Hazard.' When it is considered that upwards of 1,300,000,000 eggs are imported into this country annually, and the imports of poultry and game, alive and dead, amount to nearly $600,000 l$. per annum, it may well be imagined what a branch of agricultural industry this is! Alas, like many other things, the times are altered, yet there ought to be sufficient demand to secure more attention to this industry, and, it is hoped, to afford profit and pleasure to many a country household.

The rearing of pheasants in confinement is also a delightful and very profitable occupation. When 1 lived at Lee, in Bucks, on the borders of Herts, I had nearly three hundred hen pheasants. The birds were kept in pens about sixteen feet square, made with hurdles specially adapted for the purpose. Each pen was composed of eight hurdles about seven feet high and eight feet long, the lower half closely railed, to prevent the birds from fighting and pecking each other, also to protect them from the depredations of cats, foxes, and other vermin. These hurdles cost, when new, from 8s. to Ios. each. One cock is put to six hens; all have their wings cut to prevent their flying over. A movable house on wheels, costing about 10 ., for sheltering the man in charge, with three kennels for the dogs-which were always kept on guard-a water trough in each pen, and a few branches of holly, laurel, or other evergreen, are placed in each enclosure. The hen birds cost from $8 s$. to $12 s$. each, the cocks $5 s$. to $6 s$. Thus it would take a capital of about $300 /$. to com- 


\section{RECORDS OF OLD TIMES}

mence business, to which should be added $100 \%$ for wages, food, egg baskets, \&c., till the following May before any returns were made. With good management the returns for eggs and young pheasants would produce near upon 350 . The cost of food, wages, repairs, dog feeding, carriage, and other expenses, would be upwards of I $80 \%$, with rent and four acres of land, leaving a substantial profit for a most agreeable and interesting occupation. Within a radius of eight miles from Lee, upwards of 10,000 hen pheasants were kept, and as each hen laid during the season thirty eggs, upwards of 300,000 were laid, and mostly sold. The price at the commencement of the season early in April would be iod. each, or IOs. per doz., falling to ninepence after the first fortnight, and dropping a penny a week till the beginning of June, then it would descend to $5 d$. or $6 d$. each egg; when the price was below that sum, the pheasant farmers began to set the eggs themselves; by the middle of June there was a great demand for barn-door sitting hens, which made 4 s. to $5 s$. each. Seventeen to nineteen eggs are placed under each hen, and about twelve young ones were a fair number to hatch from each sitting. There would be an average of seven young pheasants reared to maturity.

Messrs. Dwight, who reside near Great Berkhamstead station, and Mr. Leno, of Cox-Pond Farm, near Hemel Hempstead, are the principal dealers in that district, who take eggs from the farmers, and then supply the gamekeepers of the great preserves of England, and send eggs to every 
part of the Continent, also to the United States and the Colonies. The former firm keep 2,500 hens in confinement, and in the height of the season send off, from Berkhamstead station alone, over 70,000 eggs a week, and in September supply more than 50,000 live birds for the various battues in the ensuing month. Mr. Leno also provides a large quantity, but his business is chiefly abroad. Messrs. Robb, of Liphook, in Hampshire, are as large dealers as these mentioned. The breed now chiefly used is the ring-necked variety; the old brown or ringless birds being nearly given up, but the cocks are extensively used for crossing with the ring-necked. They are considered a hardier variety, but not so prolific. The Chinese is a remarkably beautiful variety, and is often used to cross our own breeds. The roaming propensity of these birds renders them less useful than the others. It may thus be seen what a great business this egg laying and pheasant rearing has become. All the establishments I have mentioned are well worth a visit. Pheasant rearing can only be profitably conducted on suitable soils, which should be dry, and on tolerably high ground. The chalk range of the Chilterns seems peculiarly adapted for success. It may not be generally known that the pheasant is a native of Persia. The ornamental varieties are amongst the most beautiful of all the feathered creation, more especially the Golden, the Reeves, and the Impeyan birds; these make a very attractive addition to any ornamental grounds and parks. 


\section{CHAPTER XXIV}

The homing instinct-André's pigeons-Mr. Tegetmeier-Curious instances of homing instinct in the dog-Quaint epitaph-The agricultural labourer-Dialects-The agricultural labourer's rustic speech-His humour-The worth and native shrewdness of his character-His industry-Wages and the cheap loaf-Old times and new-Bounties on foreign grown sugar-The growth of flax and hemp-A chance for English agriculture-"The backbone of Old England.'

As much interest is excited at the present time by André's attempt to reach the North Pole, and a discussion has arisen as to the reported arrival of one or more of the homing pigeons which he took with him, my old friend Mr. Tegetmeier has raised the question as to the 'homing' instinct of various birds and animals. It may be interesting to record an occurrence of which I was personally cognisant some years ago, illustrating the remarkable instinct of dogs in finding their way home. When the Queen's buckhounds, in the early 'forties,' hunted the Vale of Aylesbury, the hounds were brought down in a covered van from Ascot Heath, by Gerrard's Cross, through Amersham, a distance of forty miles. The pack was housed in a large barn on their arrival at Aylesbury, and the next day the hounds were taken to Cublington, where the deer was to be uncarted, about eight 
miles from the town. The deer took a line across the country towards Winslow and Buckingham, and on to Bletchley, where he was captured after a very severe run of two hours. The horse I was riding that day, was a well known old hunter, who tired near to Winslow, and 1 was obliged to give it up. On my return through the village of Hogston, I observed in a field a stray hound wandering about, which I tried to persuade into following me, but did not succeed. That evening, when talking with Mr. Davis, the celebrated Royal huntsman, his first whip, Harry Freeman, came to him and said that one of the hounds was missing. On my asking him if it was a light coloured hound I was answered "Yes, it was Dairymaid.' I then informed him of what I had seen at Hogston, and Freeman was directed to look out for her. The next day Mr. Davis received a letter from his wife, stating that they were awakened that morning, about five o'clock, by the crying of a hound, and one of the men discovered Dairymaid at the door of the kennels. Here was a marvellous proof of a 'homing instinct' which was most surprising. The dog had been brought in a covered van for forty miles, along a turnpike road; taken for eight miles in an opposite direction to the meet, then, crossing a wild country, to Whaddon Chase; and from two o'clock in the afternoon, when I saw her, she must have travelled at least fifty miles over a perfectly strange country, and by three o'clock the next morning, in a dark November night, she arrived 
safely at her kennels in about thirteen hours. But here is another story still more wonderful. In the beginning of this century, when I was a young man, my father told me that whilst living at Amersham, the Right Hon. Mr. Ward, who, I believe, was then a Lord of the Admiralty, and lived at Hyde Heath, between Chesham and Amersham, had a very fine highly bred Newfoundland puppy, which he prevailed on my father to take charge of, and rear for him. This he did; and when the dog was nearly a year old, Mr. Ward wished him to be sent to his Yorkshire residence not far from Hull. There was much difficulty in then forwarding anything a distance of two hundred miles, and no railways, or any direct communication with the North, at that time existed. The dog was therefore sent to London, being tied under one of the broad-wheeled waggons of the day, which was drawn by eight strong, heavy horses, and carried produce to and from London. The animal was then taken to the docks, and put on board a Hull sailing packet, through the North Sea, and up the Humber to Hull, where it was met and taken to its destination some eight miles from the port. A letter was received by my father, thanking him for his attention, and informing him that the dog was greatly admired, and had arrived quite safely. About a fortnight afterwards everyone was astonished at seeing the Newfoundland enter the yard, wagging his tail, but very thin, tired, and dusty. Here was instinct combined with reason. He must have come along the Great North Road, as long 
as he thought necessary, and then struck across country for at least twenty miles, thus finding his way to the home in which he was reared. Who will therefore attempt to define where instinct ends and reason begins? Whilst writing of dogs and sport, I am reminded of an epitaph which is worth recording. It is against the north side of Harefield Church. On the outside is a monument with a representation in bas-relief of a gamekeeper and his dog, put there by a Mr. Ashby in memory of a faithful servant, Robert Morshead, who died in I 744:

In frost and snow, through hail and rain,

He scoured the woods and trudged the plain.

The steady pointer leads the way,

Stands to the scent and springs the prey.

The timorous birds from stubble rise,

IVith pinions stretch'd divide the skies;

The scattered lead pursues the sight,

And death and thunder stop the flight.

His spaniel, of true English kind,

With gratitude inflames his mind.

This servant in an honest way,

In all his actions copied 'Tray.'

Some few years since, whilst on my farm at Aylesbury, 1 received a visit from Mr. Ellis, the eminent philologist, who was desirous of testing, by oral demonstration, the special dialects of different parts of England. He brought some letters of introduction with him, and after a very interesting discussion on the peculiar pronunciation of certain districts, we commenced an ordinary conversation with the labourers while they were working on the farm. This talk was with both old and young 
educated and uneducated. We spoke of the ordinary occupations of each; of horses with the head ploughman, of sheep with shepherd, of high pedigree shorthorns with the herdsman, and of various operations with general workers. Mr. Ellis soon discovered what he required, and brought to my notice peculiarities which 1 had never noticed before, but which I soon recognised, especially those expressions and idioms which were peculiar to my district. The endings of words, with their pronunciation and flexions of language, were soon developed, and I learnt for the first time how Buckinghamshire and Oxfordshire differed from Yorkshire and Middlesex, and how Somersetshire became, as it were, almost a foreign language to the Northern Midland Counties. Yet more to be noticed than the words was the sing-song and chant of the Eastern Counties, more noticeable in Norfolk and Suffolk than in Essex. After this visit I received several letters, with inquiries, from Mr. Ellis, and with the assistance of my son Robert, who daily superintended the work of the labourers on the farm, and others in the town and neighbourhood, we prepared a careful statement, which proved of considerable utility in elucidating the subject. Much amusement ensued from the extraordinary admixture of cause and effèct, which somehow my men had got into their heads. Henry Baldwin, my well-known attendant at all the poultry shows-abroad and at home-and who was manager of the prize poultry live stock, once said, in reference to the injury the 
rain was doing to the harvest: 'It's o' no use for you to expect fine weather whilst these 'ere comicks (comets) be about, and flying along the sky'; and again he oracularly delivered himself: 'You may always know when there would be rain whenever you see them there rainbows a travelling along the top of them hills.' This was in allusion to the range of the Chilterns, which were about six miles distant, and bounded the south of the vale of Aylesbury. Another of the men had been ill, and had had the doctor to attend on him, who told my son that he, the doctor, had made a close examination of him, and told him he was suffering from 'tar in his stomick,' and that it had much alarmed him, as he could not understand how the tar had got there, and the doctor had told him he could not get well till it was removed. My son, on inquiring of the Asculapius, found that he had said 'stomachic catarrh.' Yet the observations of these men on natural appearances are very keen, and from their own long experience, and that of many, many years observation of their ancestors, their curious information could be almost implicitly depended on. They tell you it is strange but true, that when the cattle are lying about the pastures, quietly chewing their cud, during heavy rain, it is certain to clear up, with the probability of fine weather afterwards. On a neighbouring farm, where one of the chief grazing grounds was on the side of a steep hill, the cattle invariably chose the highest part of the ground during wet weather when fine was 
approaching. The bleating of sheep afforded the shepherds climatic portents; the movement of insects had meaning. It is noteworthy that the frog has a very golden skin when fine weather prevails, or is expected. The cawing of rooks, the crying of certain birds always portends a thunderstorm. The buzzing and flying, as also the biting of various insects, indicate changes in the weather.

There is a vein of quiet humour in the farm labourer which is but little known. It is the fashion to decry these honest good folk, and to give them but little credit for astuteness and originality. My experience is otherwise. I was accustomed at my harvest home to entertain my men and their wives at my residence in the town, and my wife gave them prizes for the produce of their farm gardens. There was a small lake in the grounds, with a boat upon it, and the men with their wives were perambulating the gardens, when it was considered a great achievement to be able to get into the boat and row on the water. The younger men were very desirous of getting one of the older men, Harry Mason by name, to venture into the boat, but nothing would induce him to go. When John King, the head ploughman said: 'Ah! you'll never get old Harry to leave old England !' alluding to his stepping off the bank into the boat. At the supper, one of the men remarked that he was a very quick feeder. 'Yes,' rejoined another, 'and you're a long time about it.' After the meal singing was the order of the evening; the chorus to the songs was somewhat 
uproarious, generally either deeply sentimental or broadly humorous. I am bound to say that of late the vulgarisms and coarseness of former years have been abandoned, as also the drinking to excess, although there was no stint whatever. There is no doubt that the harvest home, with the show of vegetables, was a most popular festival.

Whilst writing of my farm labourers' I am reminded of the Act passed this 'last session, the 'Workmen's Compensation Bill,' and I am bound to express my doubts as to its practicability on farms. I had most of the modern improved machinery for my farm, and was the first tenant farmer who bought his own steam cultivating apparatus. This was the so-called round-about system of Smith, of Wolstone, Bucks, who was without doubt the inventor of steam cultivation. The means by which this cultivator worked through and over the land was by the wire rope passing round a block and pulley fixed at the corners of the field, and was called an anchor. It was necessary to have a strong active young man at each anchor, to keep the wire rope in place while it was working in the groove round the pulley. The strictest orders and injunctions were given to this watcher, that on no consideration was he to handle this rope on the travelling side of the pulley, and that if the rope slipped out of the groove, he was to pull it into its place after it had passed the anchor, as if it was otherwise handled it tended to drag the hand into the implement and would severely crush it. A young man named Mason, about 


\section{RECORDS OF OLD TIMES}

eighteen years old, who superintended one of these anchors, and was son of the man who refused to 'leave old England,' most incautiously lifted the rope, which had temporarily slipped from its place, with his right hand, and it was instantly dragged into the pulley, and three of the fingers were smashed and partly torn off. As the county infirmary was within a short distance, his hand was bound up, and he walked inmediately to the hospital attended by his father. The house surgeon dressed the hand, placing the fingers into place, and the lad was put to bed in great pain, but by the evening he was quite comfortable. The next day he was so much better that he got up and walked in the grounds of the institution. By the end of the week, five days after the accident, he was still better, so that with his left hand he wheeled about, in a bath chair, another patient. The next day he complained to the matron that he had 'a stiff neck,' and had some difficulty in swallowing. She at once saw the danger of these symptoms, and on the doctor examining him, he found lockjaw had set in rapidly, and to the grief and dismay of his parents, and all of us, the next day he died of tetanus. Here was an act of the victim's own imprudence-one to be greatly deplored, as he was a promising young fellow-and the accident was caused by a portion of machinery in the open field, which was impossible to be fenced in. It would therefore be difficult to decide how the new compensation Act would work under such circumstances. No man 
has a higher appreciation of the value of the agricultural labourer than I have. His honest, hearty, co-operation in all matters, and at all times, in the work of the farm always excites my greatest admiration. Even in the science of politics he is no blockhead. I remember at a political meeting, in that aboriginal village of Lee, in Bucks, held just before the Parliamentary election for the borough and hundreds of Aylesbury, that the questions of protection and of wages were mentioned, when an old fellow got up, and with the greatest confidence addressed his brother farm workers. 'Look here,' he said, 'you may take my word for it, that cheap bread isn't everything in favour of the poor man; it's regular work as he wants; it's never no good for us when bread is under $6 d$. for the $4 \mathrm{lb}$. loaf. Now, when I was a young man, forty years ago, I went a thrashing in the barn for $9 s$. a week, and when I got home on Saturday night my wife would meet me and say, "John, I beat you," and she'd hold up a half sovereign which she had taken for her week's work for straw plaiting, making between us igs. Well then, my friends, I now get I 4 s. a week, and all as she can earn by plaiting is, 'cos o' this free trade and China plait, about $1 s$. $6 d$. or $2 s$., so we get i $5 s$. $6 d$. now against 19s. then.' Here was good common sense, and it made a great impression on me, as I am a thorough free trader and am dead against protection. Yet there are circumstances of such importance acting against the best interests of the agriculturist that I cannot be blind to their injustice. I may 


\section{RECORDS OF OLD TIMES}

mention the continental bounties on the cultivation of sugar-beet, which have quite precluded the possibility of growing sugar-beet and manufacturing it into sugar in this country, and prevented a revival of the prosperity of agriculture. I have the greatest confidence that this industry can be profitably carried on in England if fair play were accorded to us. I have given the past five years to its promotion, and feel sure that the $14,000,000 l$. sterling which we pay annually to the Continent for sugar could be saved for our colonies and our own country. I have been busy during the past two years, and have given great attention to the promotion of another great agricultural industry, which has no bounty to combat, and which I am certain can, and will be, most profitably carried into effect immediately, viz. the growth of flax and hemp. Some twenty-five years ago I grew some acres of flax most successfully on my farm, with some of my neighbours, but when grown we had no market for it nearer than Belfast, which was five hundred miles distant, so we were obliged to relinquish the cultivation. But now a company is formed called the 'English Fibres Industries, Limited,' which proposes to erect worls for treating both fibres, and bringing them into perfection in various parts of the kingdom. This year, I $\$ 97$, there are 3,000 acres being grown in the Eastern Counties, with the greatest success, and as we pay the foreigner, first and last, nearly i $8,000,000$ l. sterling per annum for these articles, it appears that there is a prospect of the future prosperity of the 
agriculturists being assured; as 1 well know, from my own practical experience, that many, if not all, of these supplies can be grown in this country at a profit of at least $3 l$. per acre. In the present day, every panacea is recommended for trial to the landowners and farmers to alleviate the present terrible distress that overspreads our land, and I feel assured that if strong efforts are made, and some assistance for this industry rendered by the Government, by affording cheap capital-which could be most satisfactorily secured-a great future is before us, and revived prosperity for agriculture, which is the greatest of all industries, in every clime and country. I express myself thus strongly on this subject, and though I am happy to write my records of sport, politics, and other matters, I am reminded by my old schooldays, of the First Ode of Anacreon :

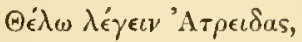

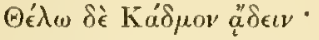

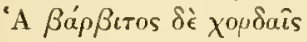

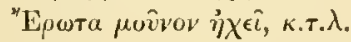

Yet my harp, instead of sounding only of love, will sing solely of agriculture.

Let us all do our best for this ennobling science, and we may then see the exodus of the labourer from the country arrested, and the fearless, industrious, and grateful countryman will again rally round the country parson, the country gentleman, and the British farmer; whilst the village tradesman and mechanic will become once more prosperous and happy, and continue to be, as they were in old times, the backbone of Old England. 


\section{${ }_{23} S$ RECORDS OF OLD TIMES}

The highly distinguished quality of our flocks and herds; the fleetness, tractability, noble bearing and stamina of our thorough-bred horses; the grandeur, strength and docility of our draught horses; with the high feeding qualities and delicacy of our porcine denizens of the farmyard, have been shown as superior to all other countries in the showyards throughout the world. Let it not then be said that our tenant farmers and their contented labourers are lacking in energy or in emulation in the great struggle that is going on throughout the world; and whilst we have our beloved Queen and our popular Prince of Wales showing themselves good farmers and lovers of the land, England has nothing to fear, and we shall be proud of our country.

Great, glorious, and free, First flower of the earth And first gem of the sea. 


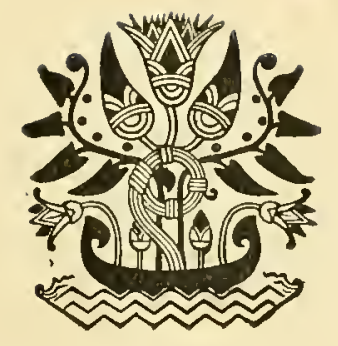





